[AMERican Journal of Science, Vol. 305, January, 2005, P. 42-100]

\title{
PATTERN OF MESOZOIC THRUST SURFACES AND TERTIARY NORMAL FAULTS IN THE SEVIER DESERT SUBSURFACE, WEST-CENTRAL UTAH
}

\author{
STEWART WILLS*, MARK H. ANDERS ${ }^{\dagger}$, and NICHOLAS CHRISTIE-BLICK \\ Department of Earth and Environmental Sciences and Lamont-Doherty Earth \\ Observatory of Columbia University, Palisades, New York 10964-8000
}

\begin{abstract}
Most tectonic models for the Sevier Desert basin, west-central Utah, envision it as the result of large-magnitude, normal-sense slip on a regional detachment fault. That interpretation, based principally on seismic reflection data, has helped shape views on the tectonics of the northeastern Great Basin area and, in a larger sense, the historical development of ideas about low-angle normal faulting. In recent years, however, several researchers have suggested, based on rock-mechanical, field, and subsurface evidence, that the hypothesized detachment fault does not exist and that the basin must have another explanation. Even among proponents of the detachment model, opinion has differed regarding the hypothesized extensional fault's total displacement, estimates for which vary widely; the timing of detachment slip; and whether the hypothesized fault represents a "new" Tertiary extensional structure or an extensional reactivation of the Mesozoic Pavant thrust. A comprehensive reinterpretation of available subsurface data for the basin, including several previously unpublished seismic profiles, suggests: (1) that slip on the hypothesized detachment must have ceased by the Miocene in the southern Sevier Desert; (2) that estimates of large-magnitude offset on the hypothesized detachment are essentially unconstrained by structural data and need to be reevaluated; and (3) that models that view the hypothesized detachment as a Tertiary extensional reactivation of a Mesozoic thrust are likely incorrect. The newly available seismic data demonstrate that reflections from the Pavant thrust do indeed closely align with reflections from the Paleozoic/Tertiary contact in many parts of the northern Sevier Desert basin; however, to the south these same thrust fault reflections are directly traceable to a position well above the down dip projection of the presumed detachment within the Paleozoic Cricket Mountains block. Erosional truncation of the thrust faults and the absence in the south of other reflections aligned with the Paleozoic/Tertiary contact preclude extensional backsliding on a Mesozoic thrust fault. These interpretations, if correct, are incompatible with the detachment hypothesis and necessitate alternative explanations for the basin's origins.
\end{abstract}

INTRODUCTION

Over the past three decades, evidence has accumulated, particularly in the North American Basin and Range province, for the role of regional low-angle, normal-sense shear surfaces in extensional processes (see references in Wernicke, 1995). These detachment faults, it has been persuasively argued, are important not merely as local gravity-glide features but as regional-scale structures fundamental to continental geodynamics (Wernicke, 1981; Gans, 1987; Lister and Davis, 1989; Wernicke, 1995, and references therein). Yet, despite extensive field study of detachments, it remains unexplained how rooted, upper-crustal normal faults dipping at angles of only a few degrees to the horizontal can slip, when classical fault mechanics (Anderson, 1942) and the record from seismicity (Jackson, 1987; Collettini and Sibson, 2001) suggest that they should initiate and move at much steeper dips. Explanations proposed to resolve this paradox have included reorientation of the tectonic stress field (Yin, 1989;

* Present address: American Association for the Advancement of Science, 1200 New York Avenue NW, Washington, DC 20005

† Corresponding author; manders@1deo.columbia.edu 
Spencer and Chase, 1989; Parsons and Thompson, 1993; but see Wills and Buck, 1997), mediation of super-hydrostatic to near-lithostatic pore-fluid pressures (Axen, 1992; Axen and Selverstone, 1994), and rotation of active high-angle normal faults into an inactive low-angle configuration over time (Proffett, 1977; Miller and others, 1983; Buck, 1988; Wernicke and Axen, 1988).

The Sevier Desert basin of west-central Utah (fig. 1) has played an important role in this evolving debate. The suggestion by McDonald (1976), based on petroleum-industry seismic and well data, that the basin's development traced to movement on an extensional detachment represented perhaps the first such interpretation based principally on subsurface information. Additional industry seismic profiles (Smith and Bruhn, 1984; Mitchell and McDonald, 1987; Planke and Smith, 1991) shed further light on the geometry of the hypothesized Sevier Desert detachment, as did a well-known series of seismic profiles shot by the Consortium for Continental Reflection Profiling (COCORP) that suggested that the $11^{\circ}$ dipping detachment continued across west-central Utah and bit deeply into the continental crust (Allmendinger and others, 1983). Wernicke $(1981,1985)$ cited the Sevier Desert basin as a type example of lithosphere-scale detachment faulting. Seismic data from the Sevier Desert also figured prominently in discussions of Great Basin faulting and basin-development styles by Anderson and others (1983) and Smith and Bruhn (1984).

Thus, in the early history of detachment-fault studies, seismic reflection data from the Sevier Desert basin constituted a subsurface analog of the spectacular outcrops of the Whipple Mountains (Lister and Davis, 1989): both examples helped spur a fundamental rethinking of extensional tectonics. In particular, the breadth and geometry of the hypothesized Sevier Desert detachment seemed to require low-angle normal-sense slip, and thereby to preclude kinematic models that called for such faults to initiate at a high angle and rotate to a gentler dip. Arguments culled from other detachment areas (see Wernicke, 1995, and references therein) have somewhat diminished the importance of that observation in the Sevier Desert. Still, the nearly $40 \mathrm{~km}$ of Tertiary extension proposed for the Sevier Desert detachment constitutes a nontrivial share of estimated total strain in the Great Basin at this latitude, and thus makes the area an important component of the regional tectonic picture that has emerged in the past 25 years (Allmendinger, 1992; Royse, 1993; Coogan and others, 1995; DeCelles and others, 1995; Mitra and Sussman, 1997).

Notwithstanding this broad acceptance, the detachment hypothesis for the Sevier Desert basin has not been free of controversy (Anders, 1993; Anders and Christie-Blick, 1994; Hamilton, 1994; Allmendinger and Royse, 1995; Otton, 1995; Coogan and DeCelles, 1996; Anders and others, 1998; Anders and others, 2001; Hintze and Davis, 2003). Indeed, many of the fundamental assumptions that underpin the consensus regarding the timing and kinematics of the proposed Sevier Desert detachmentparticularly assumptions related to the geometry of the Mesozoic thrust sheets that were reshaped by Tertiary extension, and the supposed absence of rooted intrabasin high-angle normal faults - rest on what may be an incomplete view of the subsurface data from the basin. We present here a comprehensive re-evaluation of the detachment model drawing upon both published subsurface data and some $570 \mathrm{~km}$ of previously unavailable industry seismic reflection profiles. The new data permit substantially better resolution of the three-dimensional geometry of some basin structures, especially in the southern Sevier Desert, than has been available in the past. The data place previously unappreciated timing and geometric constraints on any detachment model for the basin. They also reveal several features of the basin 


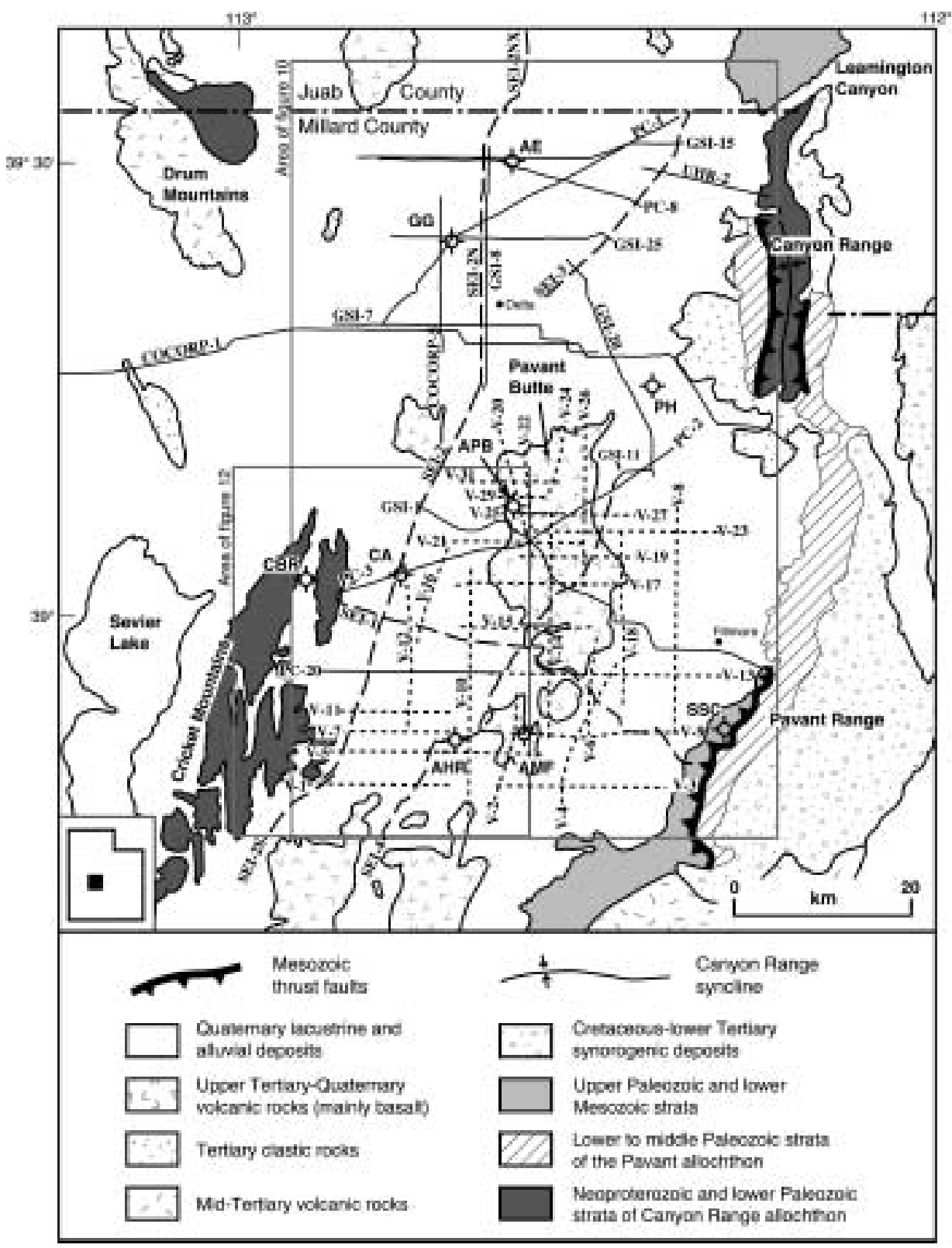

Fig. 1. Generalized map, Sevier Desert basin, showing data sources for the current study. Large gray box shows area of figure 10; smaller gray box gives area covered by figure 12. Dashed lines correspond to new seismic data loaned for this study from Seismic Exchange, Inc. (SEI); dotted lines correspond to new seismic data loaned for this study from Vastar Resources (V); solid lines correspond to Pan Canadian (PC) seismic profiles published by McDonald (1976), COCORP seismic lines published by Von Tish and others (1985), GSI lines published by Mitchell and McDonald (1987), and UHR-2 line published by Coogan and DeCelles (1996). For clarity, location of Atlantic-Richfield lines published by Planke (ms, 1987) is not shown here; location of those lines can be found in Planke and Smith (1991). All SEI lines and a large subset of the Vastar lines are published here (Appendix A) or in Wills (ms, 2000). Line SEI-4 covers much of the same path marked out by line GSI-11 (Mitchell and McDonald, 1987), but extends further south. Industry wells: AE, Argonaut Energy Federal; GG, Gulf Gronning; PH, Placid Henley; APB, ARCO Pavant Butte; CA, Cominco American Federal; CBR, Chevron Black Rock; AHR, ARCO Hole-In-Rock; AMF, ARCO Meadow Federal; SSC, Shell Sunset Canyon. For purposes of this study, northern Sevier Desert basin is the area north of the approximate latitude of the $\mathrm{PH}$ well; southern Sevier Desert basin is the area south of that latitude. Geology adapted from Hintze (1980). 
subsurface that, if correctly interpreted here, may be incompatible with the detachment hypothesis itself.

THE SEVIER DESERT BASIN

\section{Overview}

The Sevier Desert, Millard County, Utah, occupies the extreme eastern edge of the Great Basin physiographic province, and lies just west of the "transition zone" (Allmendinger and others, 1987) between the Great Basin and the Colorado Plateau. For the purposes of this paper, we take the structural Sevier Desert basin to be the area bounded on the east by the Canyon and Pavant ranges, on the west by the Cricket and Drum ranges, on the north by the Millard-Juab county line (approximately coincident with Leamington Canyon), and on the south by the $38^{\circ} 45^{\prime}$ parallel (fig. 1). As with the Great Basin generally, the Sevier Desert region stands high above sea level: the average elevation is approximately $1400 \mathrm{~m}$ in the basin, with peaks of $2140 \mathrm{~m}$ to $3080 \mathrm{~m}$ in the surrounding mountains.

As thus defined, the Sevier Desert basin occupies an area of approximately 4700 $\mathrm{km}^{2}$. Its average width, at greater than $50 \mathrm{~km}$, is more than twice the "typical" Basin and Range province dimension of 15 to $20 \mathrm{~km}$ (Stewart, 1978), although the mountain ranges surrounding the basin have about that characteristic width. Gravity maps (Cook and others, 1981; Bankey and Cook, 1989; Cook and others, 1989) underscore the basin's distinctiveness relative to surrounding areas: the relatively large length scale, continuity, and gentle gradients of the Sevier Desert basin gravity field contrast markedly with the more fragmented and steeper-gradient gravity signature north, west, and south of the basin, areas that are dominated by small, Basin and Range-scale closed gravity lows and highs (Cook and others, 1981; Bankey and Cook, 1989). Industry seismic and well data suggest that at its deepest points the basin may contain more than $4 \mathrm{~km}$ of Cenozoic sedimentary strata (mainly lacustrine terrigenous deposits and limestones) and volcanic rocks (Lindsey and others, 1981; Mitchell and McDonald, 1987).

Late Tertiary normal faults (Dommer, 1980; Holladay, 1984; Stein and others, 1988; Michaels and Hintze, 1992; Wills and Anders, 1999; Hintze and Davis, 2003) have exposed, in the mountain ranges bracketing the Sevier Desert, a succession of rocks from Neoproterozoic to Tertiary in age (fig. 1). Traditionally, the pre-Mesozoic part of this succession has been assigned to two large-scale thrust sheets (Armstrong, 1968). The structurally higher Canyon Range allochthon contains Neoproterozoic to Ordovician rocks, which crop out in the Canyon Range, on the eastern margin of the Sevier Desert, and in the Drum and Cricket ranges, to the basin's west. The structurally lower Pavant allochthon includes a nearly complete Paleozoic section (Hintze, 1993), underlain by the regional-scale Pavant thrust and by a series of smaller imbricates. Strata of the allochthon crop out in both the Pavant and Canyon ranges, at the eastern edges of the Sevier Desert basin. The thrust sheets are associated with synorogenic deposits, the characteristics of which have been used to infer the emplacement sequence of the two allochthons (Villien and Kligfield, 1986; Royse, 1993; DeCelles and others, 1995).

Conglomerates generally interpreted as post-thrusting, and as middle to late Tertiary in age, are exposed principally in the western Canyon Range, although their age, stratigraphy, and significance have constituted matters of long-standing disagreement (Campbell, 1979; Otton, 1995, 1996; Wills and Anders, 1996, 1999; Stockli and others, 2001; Hintze and Davis, 2003). Outcrops of igneous and volcaniclastic rocks in the Sevier Desert area record three main phases of volcanism: an Eocene-Oligocene period of explosive, caldera-forming magmatism marked by abundant ash-flow tuffs (Lindsey, 1982); early and mid-Miocene rhyolite outpourings (Dommer, 1980; Lindsey, 1982); and mainly 


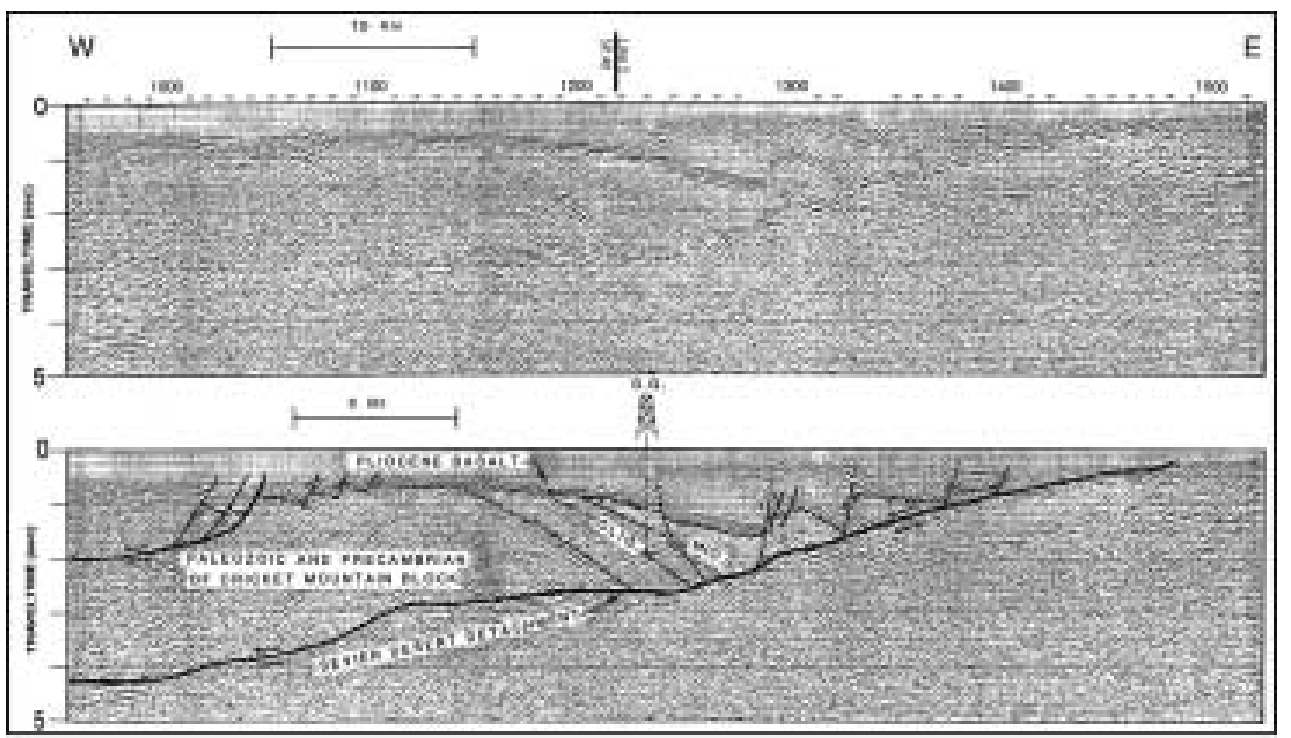

Fig. 2. Portion of profile COCORP Utah Line 1, as interpreted by Von Tish and others (1985). Interpretation shows an example of the generally accepted, detachment-fault origin of the Sevier Desert basin. (Note that our interpretation of these data, as depicted in figures 6 and 17, differs substantially from the interpretation shown here.)

basaltic volcanism in Pliocene-to-Recent time (Peterson and Nash, 1980; Turley and Nash, 1980; Nash, 1986). The first two phases are recorded almost exclusively in the area of the Drum and Thomas ranges; rocks related to the third phase crop out in a north-to-south arcuate band stretching across the basin (fig. 1).

\section{The Detachment Hypothesis}

The Sevier Desert basin differs substantially, in length scale and three-dimensional geometry, from other structural depressions in the Basin and Range province. In the mid 1970s to early 1980s, researchers began articulating a comprehensive tectonic model to explain the basin's first-order features. The model stemmed from two serendipitously timed developments: the publication of increasing volumes of industry and academic seismic reflection data, and the emergence of new ideas on the kinematics of continental extension, based largely on field studies of Cordilleran metamorphic core complexes (Crittenden and others, 1980). These coalescing developments resulted in the widely held view that the Sevier Desert basin traces to movement on a vast extensional detachment that bites deep into the continental crust and that possibly transects the entire lithosphere.

A key observation prompting the detachment hypothesis has been the striking presence, on both industry (McDonald, 1976; Smith and Bruhn, 1984) and academic (Allmendinger and others, 1983; Von Tish and others, 1985) seismic reflection profiles, of a strong, laterally continuous, multicyclic reflection that industry well data suggest is equivalent beneath the basin to the contact between Paleozoic rocks and Tertiary basin fill, and that, on some profiles, appears to continue west of the basin beneath the Cricket Mountains block (fig. 2). Overlying the reflection within the basin are structural graben bounded by faults that apparently terminate at or sole into the reflection, which itself is not significantly offset by the high-angle normal faults. Drawing on experimental physical models of Gulf Coast detached extensional deforma- 
tion by Cloos (1968), McDonald (1976) suggested that these seismic reflection patterns were most easily explained if the basin had been created by Tertiary extensional reactivation of a preexisting Mesozoic thrust. The Sevier Desert detachment hypothesis quickly became the standard model for the basin's formation, although opinions have differed as to whether the structure represents an extensionally reactivated thrust (McDonald, 1976; Mitchell and McDonald, 1986; Coogan and others, 1995) or an entirely new extensional feature of Cenozoic age (Wernicke, 1981; Von Tish and others, 1985; Planke and Smith, 1991; Stockli and others, 2001).

Otton $(1995,1996)$ and Stockli and others (2001) further limned the detachment hypothesis in studies of the eastern margin of the northern Sevier Desert basin. Otton $(1995,1996)$ argued that the contact between Paleozoic rocks and Tertiary conglomerates on the western side of the Canyon Range, previously held to be unconformable, in fact represented a fault contact, and that the fault constituted the breakaway zone of the regional Sevier Desert detachment. Otton's hypothesis rested on evidence of brittle deformation in the Paleozoic quartzites that constituted the putative footwall block. [Wills and Anders (1996, 1999), however, observed that the areas of maximum deformation cited by Otton tend to correspond to mapped fold hinges and faults associated with the pre-Tertiary Sevier orogeny, and suggested that the brittle deformation could thus be related to Mesozoic thrusting rather than Tertiary extension.] Stockli and others (2001) presented apatite fission track data and modeling that pointed to a significant mid-Miocene cooling event in the Canyon Range, and suggested that the data marked rapid extensional unroofing of the range along an $\sim 35$ to $40^{\circ}$ west-dipping fault that they identified with the fault hypothesized by Otton (1995, 1996) and that they held marked the breakaway zone of the Sevier Desert detachment.

Early studies of Sevier Desert tectonics, while favoring a detachment model for the basin, acknowledged the mechanical paradoxes implicit in regional-scale low-angle normal faulting (see, for example, Allmendinger and others, 1983; Smith and Bruhn, 1984). That consideration aside, however, the detachment hypothesis has proven to be a remarkably powerful tool for explaining many first-order geological and geophysical observables in the Sevier Desert basin. Most important, perhaps, it provides an explanation for the existence, scale, and east-west asymmetry of the basin itself, as well as for its dominant seismic geometry. It has also been suggested (Allmendinger and others, 1983; Allmendinger and Royse, 1995) that footwall uplift along a doming detachment surface offers the simplest explanation for the broad gravity high west of the Canyon Range, and for Miocene fission-track ages in crystalline basement sampled in the ARCO Meadow Federal No. 1 well, in the southern Sevier Desert. Palinspastic restorations of detachment-related extension have formed the basis for a number of influential studies on the Mesozoic compressional tectonics of the area (Villien and Kligfield, 1986; Royse, 1993; Coogan and others, 1995; DeCelles and others, 1995; Mitra and Sussman, 1997).

\section{Arguments Against the Detachment Hypothesis}

In view of its broad first-order explanatory power, the detachment hypothesis remains the favored explanation for the Sevier Desert basin. In recent years, however, a number of arguments have surfaced that cast doubt on the detachment explanation.

Outcrop and subsurface studies. - Hamilton (1994) argued against the detachment interpretation based on outcrop studies on the eastern margin of the basin [but see Otton (1995, 1996) and Stockli and others (2001)]. Anders (1993), Anders and Christie-Blick (1994), and Anders and others (2001) focused on evidence from the subsurface. Examining cuttings and core from both above and below the hypothesized detachment near the fault contact, they found no statistically significant difference between microfracture density in material within $3 \mathrm{~m}$ of the inferred fault contact and 
background levels from samples further uphole, contrary to studies of well-exposed faults, which reveal a pronounced increase in microfracture density close to even small-displacement faults (Brock and Engelder, 1977; Anders and Wiltschko, 1994). Moreover, carbonate rocks in core and cuttings from below the contact showed no evidence of ductile deformation, even though, under any detachment model, the rocks would have been dragged up from from a depth of more than $14 \mathrm{~km}$, with an estimated temperature at the initiation of faulting of $425^{\circ} \mathrm{C}$ (Anders and others, 2001). Anders and Christie-Blick (1994) suggested that, in light of the absence of expected fault-related deformation, the high-amplitude reflection observed on seismic profiles in the Sevier Desert basin more likely marks an unconformity between Tertiary and Paleozoic rocks than a fault contact. They speculated that the apparent continuation of the feature beneath the Cricket Mountains block in northern profiles traced to a fortuitously aligned thrust fault.

Differences between northern and southern basin.-In addition to these published dissenting views, a number of other potential internal inconsistencies exist in the detachment interpretation that have perhaps been insufficiently appreciated in the literature. One such line of evidence lies in profound differences between the subsurface record of the northern Sevier Desert basin and that of the southern basin. The most compelling evidence for detachment faulting has come from seismic profiles in the northern Sevier Desert, which show apparent continuity or quasi-continuity between the basin-floor reflection and a high-amplitude, west-dipping event beneath the Cricket Mountains block (fig. 2). Yet that pattern, although seen on virtually all industry and academic seismic profiles north of line GSI-1 (Allmendinger and others, 1983; Von Tish and others, 1985; Mitchell and McDonald, 1987), is nowhere apparent south of that line. Instead, in the southern profiles (Mitchell and McDonald, 1987; Planke, ms, 1987; Planke and Smith, 1991), seismic events tied to the basin-flooring reflection abruptly terminate at or a short distance beneath the Cricket Mountains block, without the apparent west-dipping continuation of those events that is so suggestive of a through-going crustal fault in the northern profiles. Studies in the northern and southern basin have also yielded dramatically different estimates of total extension along the detachment. Research in the northern Sevier Desert basin, relying on displacements of assumed Mesozoic thrust-fault cutoffs across the detachment surface, has suggested a minimum displacement of $28 \mathrm{~km}$ to $38 \mathrm{~km}$ (Von Tish and others, 1985) or more (Coogan and DeCelles, 1996). Planke (ms, 1987) and Planke and Smith (1991), using a method based on cross-sectional area balance of displaced Tertiary rocks and growth strata, calculated total extension at only $6.2 \mathrm{~km}$, based on seismic data from only $20 \mathrm{~km}$ south of the COCORP profile used to derive the far greater extension estimate of Von Tish and others (1985).

Timing inconsistencies. - Another possible internal inconsistency in the detachment model involves the relationship between the timing of sedimentation within the basin and of uplift in surrounding areas. As noted above, Stockli and others (2001) have presented apatite fission track data suggesting significant cooling in the Canyon Range, on the eastern margins of the Sevier Desert, between 19 and $15 \mathrm{Ma}$, and suggested that this marked uplift and unroofing of the range as the breakaway zone of the Sevier Desert detachment. Kinematic models of detachment faulting (for example, Wernicke, 1985; Lister and Davis, 1989; Friedmann and Burbank, 1995) suggest that footwall uplift of the breakaway zone should be among the earliest consequences of detachment faulting. Yet Mitchell and McDonald (1987) argued that the Sevier Desert

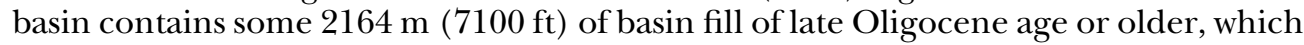
suggests that a substantial sedimentary basin must have already existed at that point. Moreover, Anders and others (1998) showed that there is a minimum of 0.5 seconds of two-way travel time (or about $1 \mathrm{~km}$ based on regional velocity structure) in the basin fill 
directly below the stratigraphic level dated at 26 Ma to 28 Ma by Lindsey and others (1981). If this basin was created by detachment faulting, then the data from the Canyon Range and the central basin, taken together, imply an unexplained lag of at least 10 million years between detachment initiation and uplift of the breakaway range. ${ }^{1}$

In the view of most of the geologic community, the strengths of the detachment model, in explaining the shape, dimensions, and seismic geometry of the basin and the presumed stratigraphy and structure of the surrounding blocks, still outweigh the potential deficiencies outlined above. Nonetheless, those potential deficiencies are sufficient to make a consideration of possible alternative hypotheses desirable. Toward that end, in the balance of this paper, we reexamine industry well data and seismic profiles from the basin (fig. 1) in an effort to place bounds on hypotheses that might explain the first-order observations there.

SUBSURFACE DATA SET

The data set in this reinterpretation includes nine petroleum-industry wells, drilled between 1959 and 1995, that pierce various parts of the Sevier Desert section to depths of up to $5327 \mathrm{~m}(17,477 \mathrm{ft})$ and that constitute the principal source of information on the subsurface distribution of pre-Tertiary and Tertiary rocks within the Sevier Desert basin (figs. 3 and 4). This study also draws on a substantial suite of industry and academic seismic reflection profiles (fig. 1), including data previously published and interpreted by McDonald (1976), Von Tish and others (1985), Mitchell and McDonald (1987), and Planke (ms, 1987) as well as approximately $570 \mathrm{~km}$ of previously unavailable industry data, especially from the southern Sevier Desert, provided by Vastar Resources and Seismic Exchange, Inc. (SEI); a selection of these profiles, originally presented in Wills $(\mathrm{ms}, 2000)$, is included in appendix A. These data were generated under widely varying processing streams. Only a small fraction of the profiles are migrated; moreover, datum statics and replacement velocities vary. The latter issue did not pose too serious a problem for most of the basin, however, as the bulk of the profiles are datumed approximately to the surface elevation of the basin. A notable exception is COCORP Utah Line 1 (Allmendinger and others, 1985), which has a much higher datum elevation and replacement velocity than the industry data, and which thus had to be corrected to be consistent with those profiles.

The analysis presented herein has relied heavily on profiles initially published by McDonald (1976), Allmendinger and others (1983), Von Tish and others (1985), Mitchell and McDonald (1987), and Planke (ms, 1987). The newly published Vastar and SEI profiles provide additional insight on possible high-angle structures on the northern, western, and southern edges of the basin, the complex faulting patterns in the central basin, the possibility of high-angle normal faulting at the eastern margin, and the three-dimensional geometry of Mesozoic thrust faults. Although the industry exploration well record in the basin has improved significantly since the initial study of McDonald (1976), the number of wells available to constrain the analysis remains small

${ }^{1}$ Stockli and others (2001) have disputed this point, arguing instead that the basin contains no pre-Miocene strata and thus the fission track dates from the Canyon Range are fully consistent with the initiation of motion on the Sevier Desert detachment. Ultimately, that assertion rests on the work of Von Tish and others (1985), who tied a key dated Oligocene unit (Lindsey and others, 1981) from the Gulf Gronning well (discussed below) to an east-tilted panel of reflections in the hypothesized detachment's hanging-wall block. Under this model, deposition of the Oligocene unit thus predated basin formation and was unrelated to detachment faulting (Stockli and others, 2001). The Gulf Gronning well was not acoustically logged, however, and the seismic tie on which Von Tish and others (1985) based their model requires an estimated sonic velocity for the rocks penetrated by the well that is considerably slower than the velocity for other, acoustically logged wells penetrating Tertiary strata in the basin. Applying a velocity more consistent with the data from the other wells places the Oligocene unit from the Gulf Gronning well clearly within the basin fill (Mitchell and McDonald, 1987; Anders and others, 1998). 


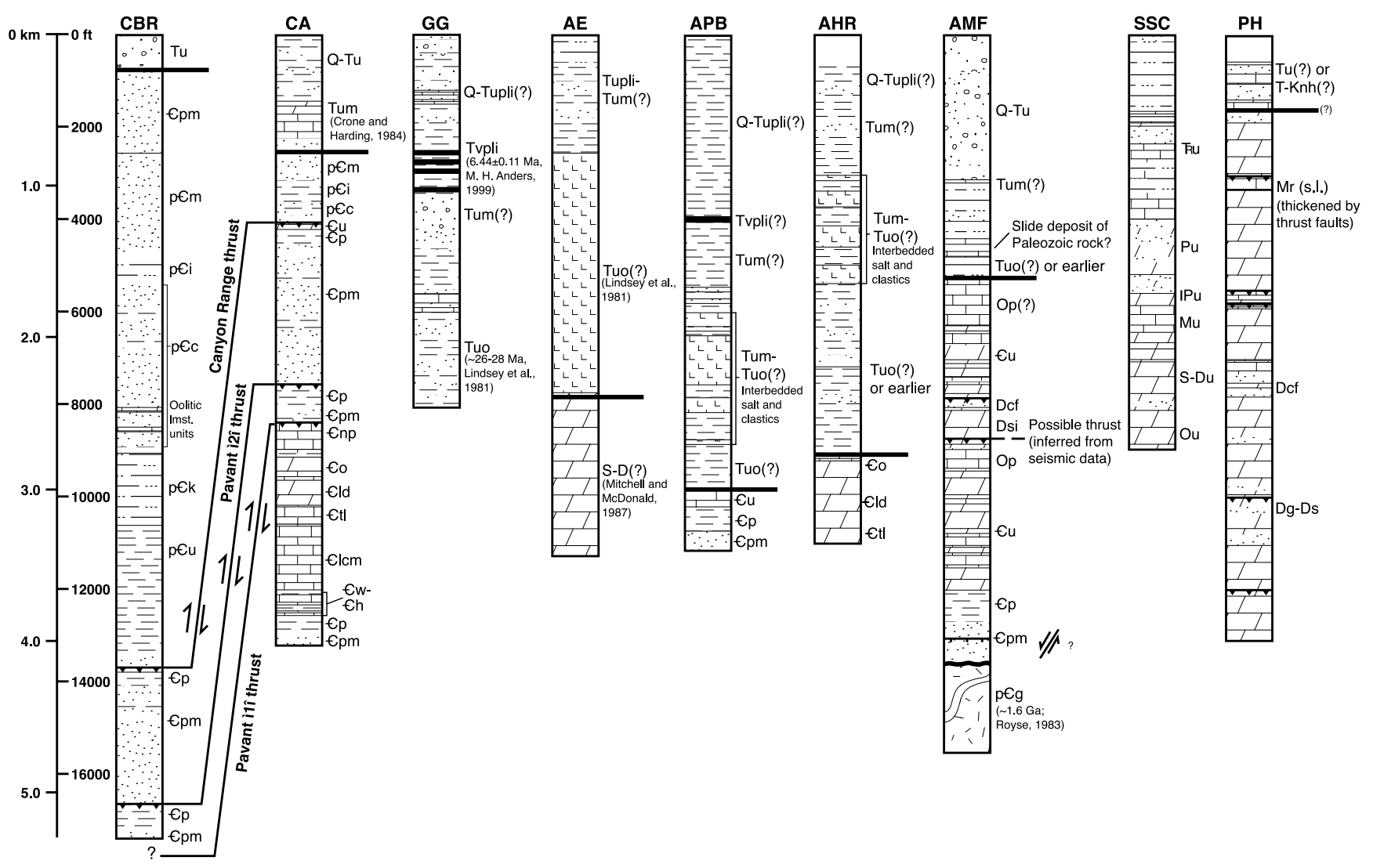

Fig. 3. Summary of well interpretations, based on geophysical and sample logs and examination of cuttings. Well names are given in caption to figure 1 . Key to abbreviations and symbols appears in figure 4. 
Geological units:

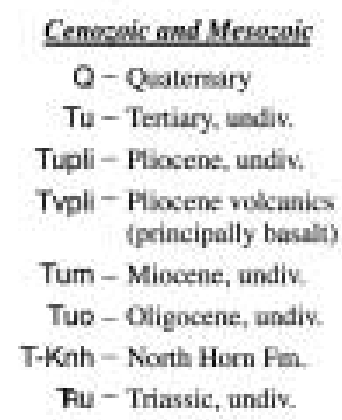

Key to symbols:

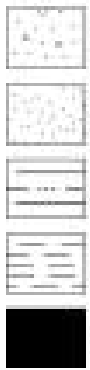

Conglomernite

Sandstoese and quartribe

Silrspone

Claystome and

shale

Basalt

\section{Pakozoic and Precoubrian}

Pu-Permian, undiv,

IPu-Pentasylvanian, undiv.

Mr-Rediwall Limestone

Mu - Mississippian, undiv.

Det - Cove Fort Quartzite

Dg-Guilmeste Fm.

Dsi-Sinvenson Dokamite

Ds-Sevy Dolomite

S-Du-Silum-Dev, undiv.

Op - Pogunip Group

Ou-Ordovician, undiv.

Enp-Noech Peak. Fm.

$60-O r r m$

fid-Lamb Dolemite

EtI-Trippe Limestone
Elem-Limestoex of Crickes Mountains

$C w-C h-$ Whirlwind Fm. wo Howell Limestone

Eu-Cambrian carbonates, undiv,

Ep-Pioche Pm.

Epm-Prospect Min. Qtzt.

pem-Mutual Fm.

peí- Inkom Fm.

pec - Caddy Canyon Qtas. and equivalents

pex - Kelley Cusyon Fm.

peu - Undivided Neoprot.

pEg-Precambrian gnciss

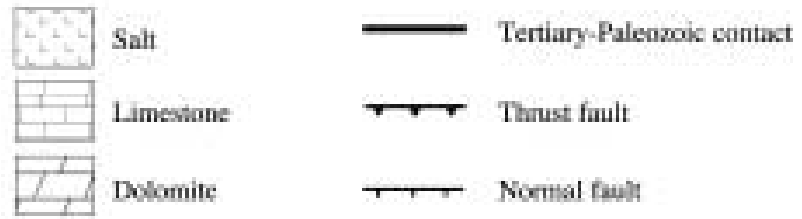

Fig. 4. Key to abbreviations and symbols in figure 3 .

in view of the basin's large geographical area and substantial internal complexity. Thus few horizons can be mapped basin-wide with any confidence, and interpretation of individual reflections far from well control inevitably has a qualitative flavor.

INTERPRETATION OF SUBSURFACE DATA

The gross geometry of dip-oriented seismic profiles has been well described by Allmendinger and others (1983), Von Tish and others (1985), Mitchell and McDonald (1987), and Planke (ms, 1987). In the discussion that follows, we emphasize five general themes important to any working hypothesis of basin formation: subsurface evidence regarding the characteristics and age of the Tertiary strata that constitute most of the basin fill; patterns of onlap and stratal tilt that constrain basin models; the overall basin geometry, as indicated by a contour map of the surface separating Tertiary basin fill from older rocks; the distribution of pre-Mesozoic strata and geometry of Mesozoic thrust faults; and seismic evidence for high-angle structures (of relatively small offset).

\section{Characteristics and Age of Tertiary Strata}

Eight of the nine industry wells studied (fig. 3) penetrate Tertiary strata, with five of them sampling in excess of $1 \mathrm{~km}$ of Tertiary sedimentary and volcanic rocks. The 
well record suggests that virtually all of the basinal strata are lacustrine in origin, consisting predominantly of fine-grained siliciclastic and volcaniclastic deposits, micritic freshwater limestones, and evaporites. Two of the wells, Gulf Gronning No. 1 (GG) and ARCO Pavant Butte No. 1 (APB), also sample flows of green or black basalt or basaltic andesite (McDonald, 1976; Planke, ms, 1987). Although several wells penetrate intervals of conglomerate, coarse clastic rocks in general are notably absent from most of the Sevier Desert Tertiary record. Four of the wells, GG, APB, ARCO Hole-In-Rock (AHR), and Argonaut Energy Federal No. 1 (AE) also penetrate intervals

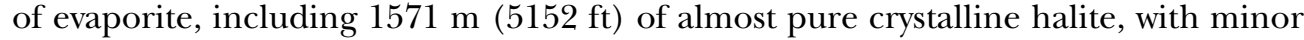
anhydrite, in the AE well (Mitchell, 1979; Lindsey and others, 1981; Mitchell and McDonald, 1987), zones of salt interbedded with siliciclastic sediments and minor limestones in APB (264 m net salt) and AHR (252 m net salt), and minor bedded or nodular anhydrite in GG (McDonald, 1976; Lindsey and others, 1981).

Age data for the Tertiary strata are spotty at best. For perhaps the most intensively studied and discussed of the basinal holes, GG, Lindsey and others (1981), using zircon and apatite fission-track dating, concluded that a tuffaceous sandstone unit approximately $350 \mathrm{~m}$ above the bottom of the hole is latest Oligocene, or 26 to $28 \mathrm{Ma}$, in age, a date that they held was consistent with pollen obtained from the same cored interval. It is thus generally inferred that the GG hole bottoms in upper Oligocene rocks, though interpretations of seismic data suggest that more than $2 \mathrm{~km}$ of earlier Tertiary material may lie in the deepest part of the Sevier Desert basin (Mitchell and McDonald, 1987). Lindsey and others (1981) also cited an unpublished K-Ar date of 4.2 $\pm 0.3 \mathrm{Ma}$ for the second of the well's five basalt flows, at $812 \mathrm{~m}(2664 \mathrm{ft})$. Our ${ }^{40} \mathrm{Ar}^{39}{ }^{39} \mathrm{Ar}$ dating of that flow suggests an older, $6.44 \pm 0.11$ Ma age (fig. 5 ).

$\mathrm{APB}$, in the central basin, penetrates $2987 \mathrm{~m}(9800 \mathrm{ft})$ of predominantly siliciclastic and volcaniclastic Cenozoic fill qualitatively similar to the section logged in GG, albeit with a thinner basalt layer and with thicker evaporitic intervals. Absent quantitative data, the basalt layer in APB has usually been correlated with the dated Miocene basalt in GG, approximately $34 \mathrm{~km}$ to the northwest. The Cominco American Federal No. 1 (CA) hole, on the western basin margin, passed through some $768 \mathrm{~m}(2520 \mathrm{ft})$ of Tertiary and Quaternary section, including a carbonate interval for which Crone and Harding (1984) have cited a Miocene age. For the five other holes in the Sevier Desert basin area that penetrated Tertiary strata-AHR, AE, the Chevron Black Rock Federal No. 1 (CBR) well, some $11 \mathrm{~km}$ west of CA, the Placid Oil Henley No. 1 (PH) industry well on the eastern basin margin, and the ARCO Meadow Federal No. 1 (AMF) well, in the southern basin-no isotopic or fossil age data have been reported.

\section{Patterns of Onlap and Stratal Tilt}

Three general stratal patterns evident in the seismic record bear on the tectonic evolution of the Sevier Desert basin: onlapping of Tertiary strata against tilted Paleozoic and Neoproterozoic rocks of the Cricket Mountains block; passive tilting of preexisting flat-lying sediments against listric faults; and "growth" strata related to detachment faulting or to possible salt withdrawal. The dominant stratal and faulting geometries vary from north to south in the basin (figs. 6 and 7).

Onlap against the Cricket Mountains block.-Seismic reflection profiles from the western edges of the Sevier Desert basin show an uneven surface, dipping eastward at an angle of $5^{\circ}$ to $20^{\circ}$. Virtually all profiles in the basin show flat-lying or gently east-tilted reflections terminating against this surface in a pattern best described as stratal onlap (fig. 8). The record of the Gulf Gronning well suggests that the onlapping reflections lie in the basin fill, and the records of the CA and CBR wells are consistent with an identification of rocks beneath the east-tilted, onlapped surface as lying within the Cricket Mountains block. Thus, we interpret the east-tilted surface as the unconformable contact between Tertiary rocks and underlying folded-and-thrusted Paleo- 
A

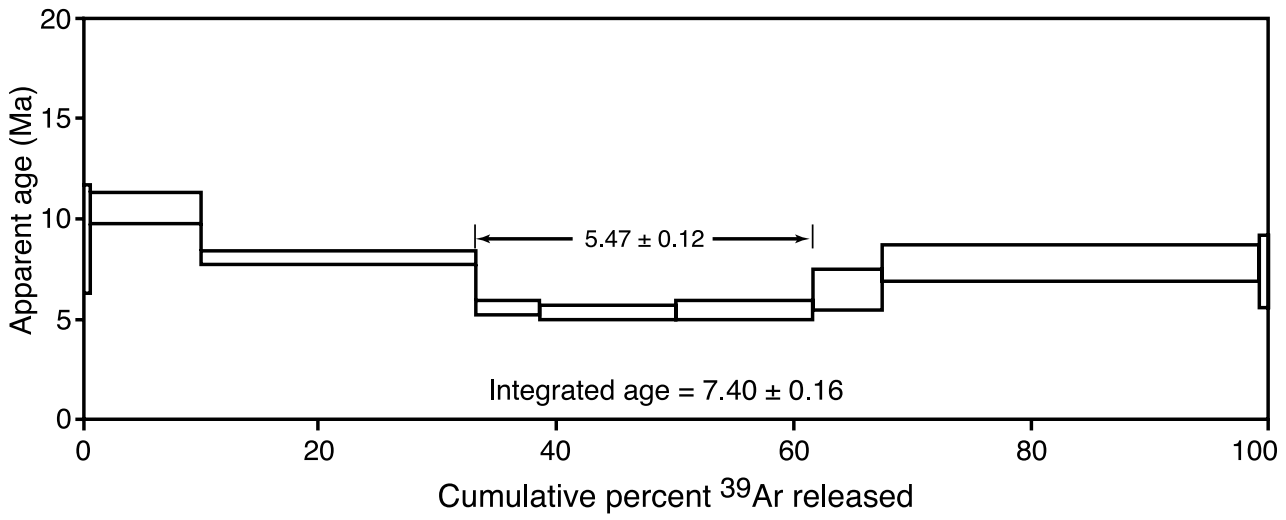

B

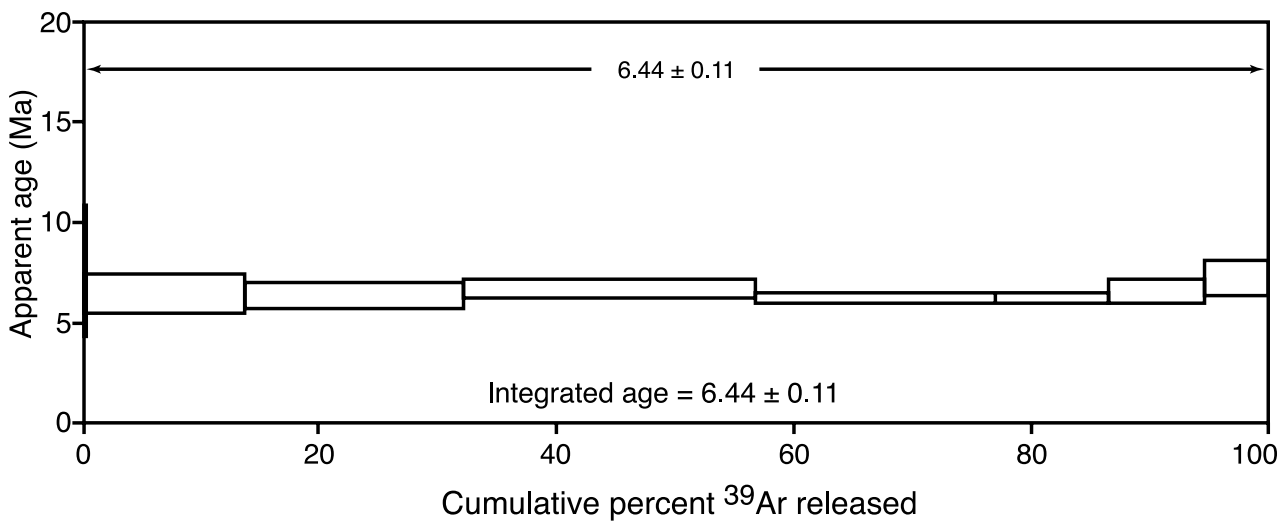

Fig. 5. ${ }^{40} \mathrm{Ar}-{ }^{39} \mathrm{Ar}$ age spectra for two basalt flows in Gulf Gronning well. (A) Spectrum for basalt flow at $765 \mathrm{~m}$ (2510 ft). Pattern of argon release suggests that the date may be unreliable. (B) Spectrum for basalt flow at $812 \mathrm{~m}(2664 \mathrm{ft})$. Pattern of argon release suggests a reliable date of $6.44 \pm 0.11$ Ma, approximately 2 million years older than the date cited for the same flow by Lindsey and others (1981).

zoic and Neoproterozoic strata of the Cricket Mountains block. While some local variation exists, in general the pattern of onlap against a probable erosional unconformity persists in profiles from both the northern and southern basin, and raises at least the possibility that the data reflect passive subsidence of preexisting erosional topography rather than the active tectonics of detachment faulting. ${ }^{2}$

Listric normal faulting without significant stratal growth.-A second important seismic geometry, seen mainly in data from the southern Sevier Desert basin, involves strata passively tilted along listric normal faults. Planke (ms, 1987) and Planke and Smith

${ }^{2}$ As discussed above, some authors (McDonald, 1976; Von Tish and others, 1985; Coogan and DeCelles, 1996; Stockli and others, 2001) have interpreted the upper reflections of the section below the onlapped unconformity as a tilted succession of "older Tertiary" strata that unconformably overlie the Paleozoic rocks of the Cricket Mountains block, that were laid down before detachment faulting, and the age of which thus places a lower limit on the initiation of detachment faulting. This interpretation, however, appears to rest on an incorrect reading of the likely sonic velocity for material sampled by the Gulf Gronning well (Anders and others, 1998). 

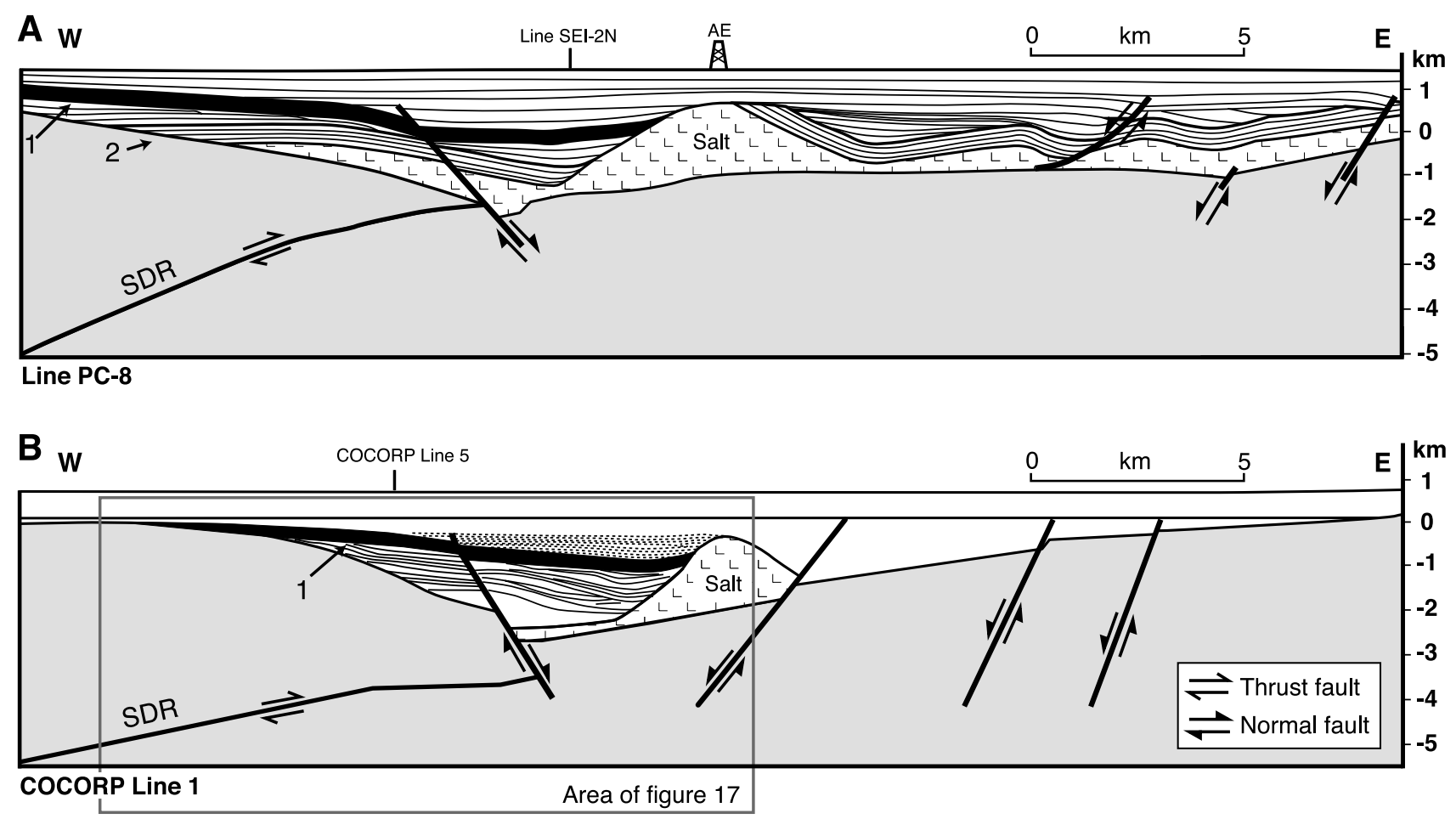

Fig. 6. Line drawings, depicting interpretations of seismic reflection profiles (A) PC-8 (McDonald, 1976) and (B) COCORP Utah Line 1 (Allmendinger and others, 1983), from northern Sevier Desert basin. Vertical axis is depth in kilometers; no vertical exaggeration. Open half-arrows depict thrust faults; filled half-arrows depict normal faults. AE is Argonaut Energy well. Unit 1 in (A) and (B) is a succession of interbedded basalt flows and clastic sediments penetrated by the Gulf Gronning well (figure 2) that is clearly imaged on seismic profiles from the northern basin. Unit 2 in (A) is a set of subparallel reflections on line PC-8 that are interpreteted in this study as a single marker unit for purposes of the restoration shown in figure 22 . Outline box in (B) gives area of figure 17. Gray corresponds with pre-Tertiary strata; the remainder of the of the restoration shown in figure 22. Outline box in (B) gives area of figure 17. Gray corresponds with pre-Tertiary strata; the remainder of the
section is interpreted as Tertiary basin fill, and the intervening contact as an unconformity. Geometry of basin fill is dominated by sizable wedges section is interpreted as Tertiary basin fill, and the intervening contact as an unconformity. Geometry of basin fill is dominated by sizable wedges of growth strata, in many cases flanking antiformal or domal structures known or inferred to be salt-cored. SDR is the down-dip portion of the
Sevier Desert reflection, commonly interpreted as the Sevier Desert detachment fault, but interpreted in this study as the Pavant thrust fault. See text for details. 
A W

Line SEl-2 Line V-12

$0 \mathrm{~km} 2$

Line SEl-4

E
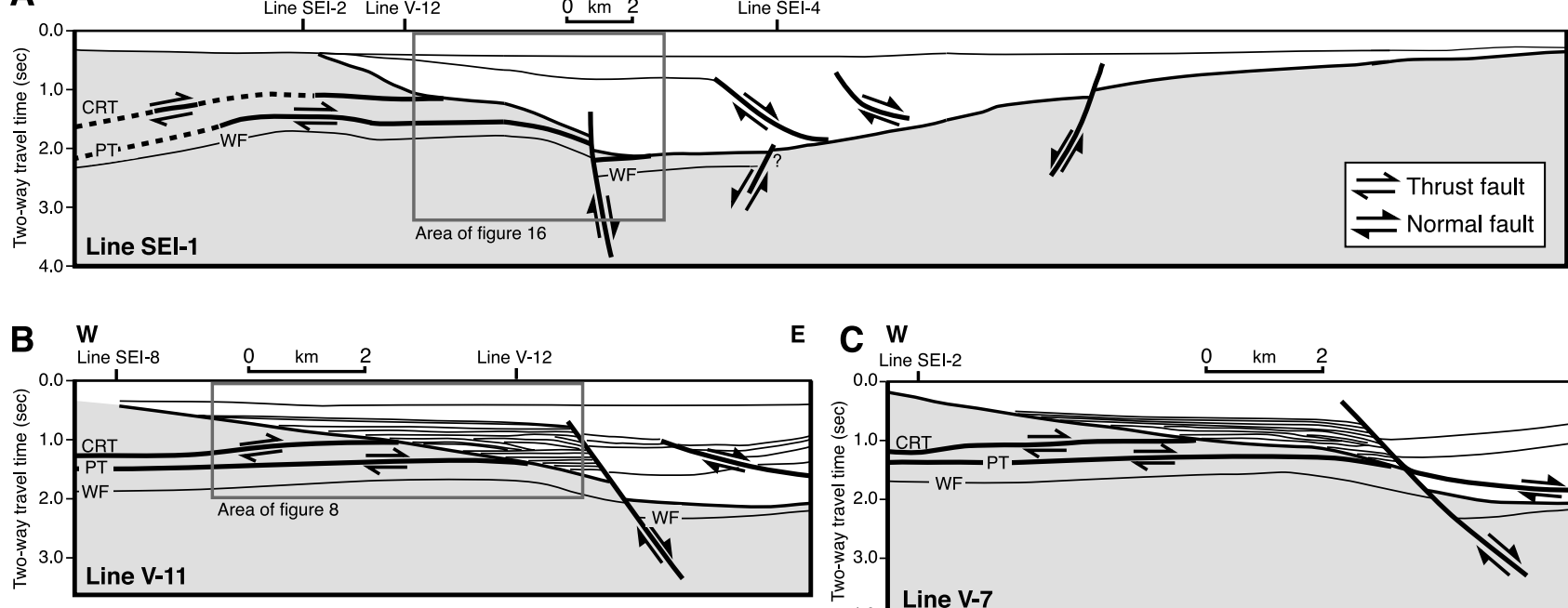

E C W

E

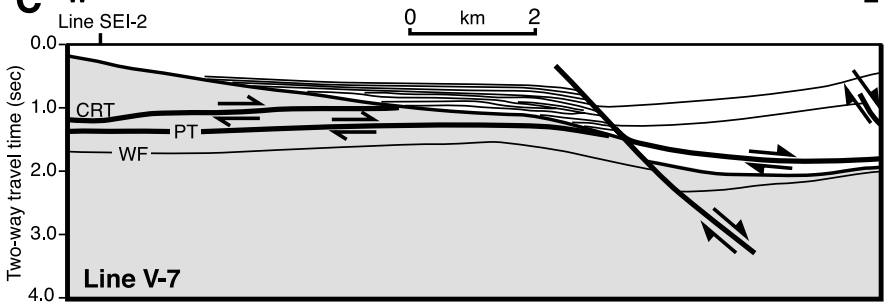

D $\mathbf{w}$

4.0 Line V-7

Sevier Desert basin. Vertical axis is seconds of two-way travel time Open half-arrows depict thrust faults; filled half-arrows depict normal faults. Gray Sevier Desert basin. Vertical axis is seconds of two-way travel time. Open half-arrows depict thrust faults; filled half-arrows depict normal faults. Gray
indicates pre-Tertiary strata; white indicates Tertiary basin fill. The intervening contact is Paleozoic-Tertiary unconformity. Complex internal stratal geometry of profile SEI-1, from central Sevier Desert basin, is shown as interpreted by Wills (ms, 2000). Profiles V-5, V-7, and V-11, from southern Sevier Desert basin, are dominated by listric faults that displace panels of reflections associated with comparatively little stratal growth; those panels in turn are overlain by smaller growth panels. All profiles display a pattern of stratal onlap against the Paleozoic-Tertiary unconformity in the Cricket Mountains block. Note also persistent presence of basin-bounding high-angle normal faults (of relatively small offset), and west-dipping surfaces (likely representing Mesozoic thrusts or tilted Paleozoic strata) below the basin, especially in profiles V-5 and V-7. CRT - Canyon Range Thrust; PT - Pavant Thrust; WF Whirlwind Formation (s.1.). See text for details. 

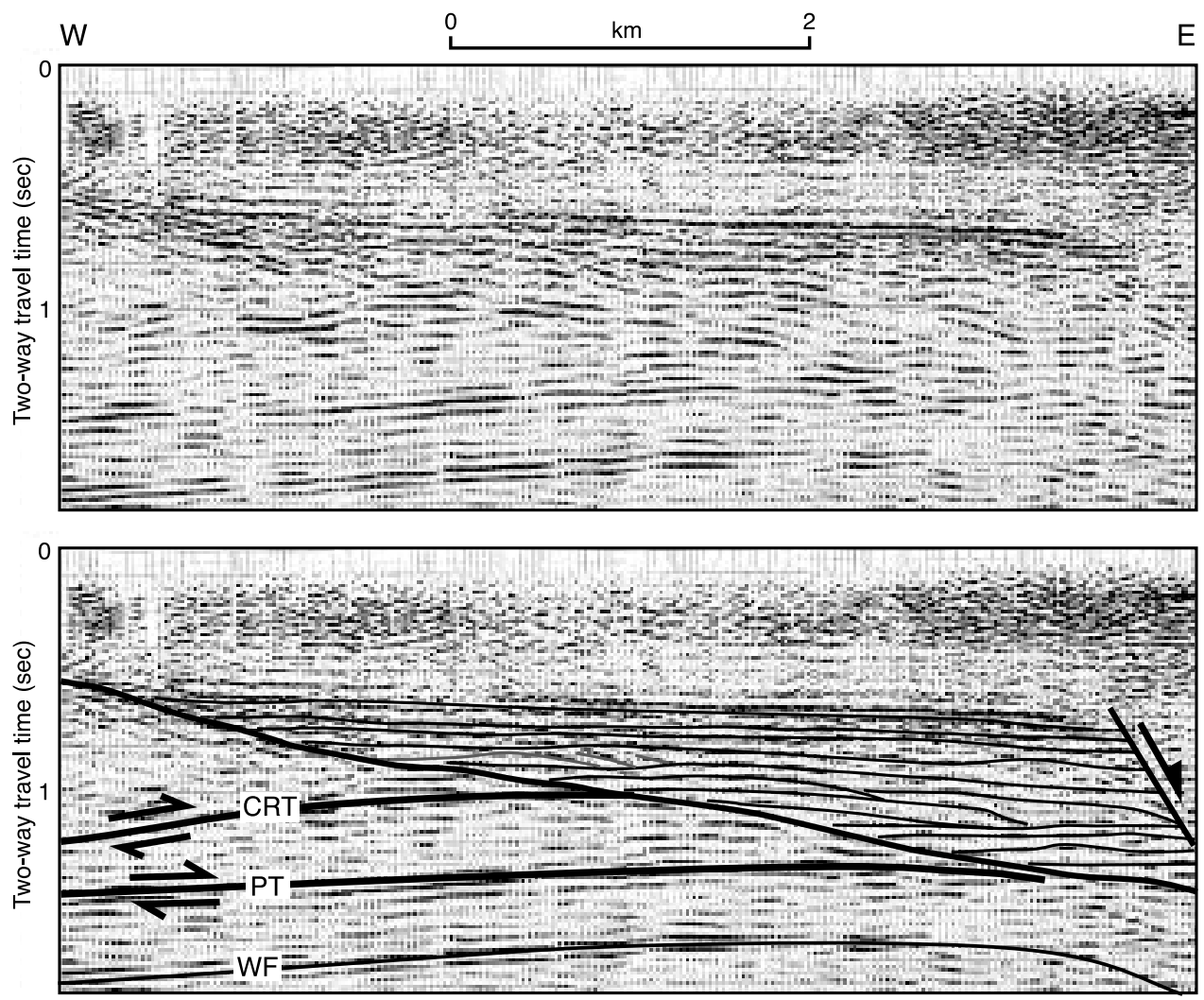

Fig. 8. Detail of line V-11, southwest Sevier Desert, showing onlap against Paleozoic-Tertiary unconformity of the Cricket Mountains block. Surfaces beneath unconformity in Cricket Mountains block: CRT, Canyon Range thrust; PT, Pavant thrust; WF, Whirlwind Formation (s.l.). Seismic data provided by Vastar Resources, Inc.; interpretation is that of the authors.

(1991) observed this pattern in industry seismic data from the southern Sevier Desert basin, and suggested the existence of a "master" western-basin-bounding listric fault that soles into the Sevier Desert detachment. A noteworthy characteristic of the fault geometry is the lack of significant stratal growth in the tilted sedimentary section (fig. 9). Instead, the tilted strata, which are well imaged on a variety of industry seismic data from the southern Sevier Desert basin, appear to have been tilted into position after deposition as flat-lying units, with normal drag along the fault surface. The tilted strata are thus probably correlative with layers west of the listric fault that onlap onto the Cricket Mountains block. Growth strata observed in this profile are mainly high in the section; as discussed below, these strata may be partly related to late-stage motion along a high-angle normal fault that bounds the basin and apparently cuts the PaleozoicTertiary unconformity.

Planke (ms, 1987) dated motion along this basin-bounding listric fault as midPliocene or younger, apparently on the basis of his interpretation of a high-amplitude reflection in the footwall block as equivalent to basalts sampled in the GG well, in the northern Sevier Desert basin. Seismic ties unavailable to Planke (ms, 1987), however, suggest that this reflection more likely traces to a Miocene limestone unit (Crone and Harding, 1984) sampled by the CA well. Thus movement along the listric basinbounding fault can probably be constrained only to Miocene or younger. 

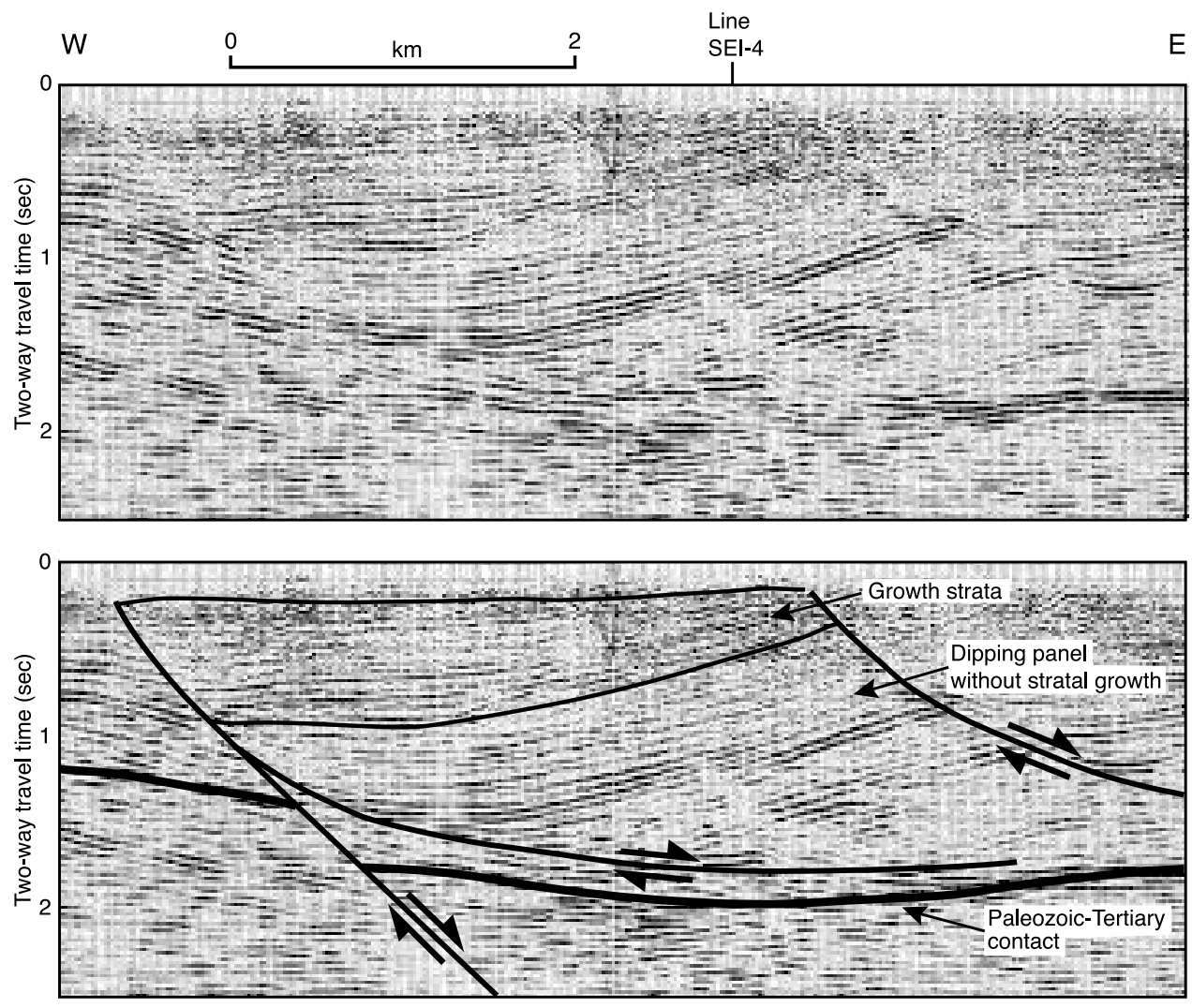

Fig. 9. Detail of line V-5, showing pattern of stratal tilt without significant growth. Growth strata at top of section are apparently related to high-angle normal fault imaged on line SEI-4. Seismic data provided by Vastar Resources, Inc.; interpretation is that of the authors.

High-angle planar and listric faults with significant stratal growth.-The pattern of basin-bounding faults in the southern Sevier Desert basin differs substantially from the geometry seen in the north, where planar and listric faults associated with growth strata predominate. Examples include a classic growth wedge adjacent to a large salt structure in the extreme northern basin (plate II in McDonald, 1976) and growth synclines in the central basin (plate 3A in Mitchell and McDonald, 1987). Most authors attribute these patterns of stratal growth to extension along the Sevier Desert detachment (McDonald, 1976; Von Tish and others, 1985; Mitchell and McDonald, 1987; Planke, ms, 1987 ; Coogan and DeCelles, 1996), although Anders and Christie-Blick (1994) suggested that they may relate to withdrawal of early-deposited salt.

\section{Basin Geometry}

Four wells within the Sevier Desert basin and east of the Cricket Mountains block-AE, APB, AHR, and AMF-penetrated the contact between Tertiary basin fill and older (generally Lower Paleozoic) rocks. These wells can be tied, using sonicvelocity log data, to a strong, generally west-dipping reflection that appears on all seismic profiles from the Sevier Desert and that can be mapped with confidence throughout the basin east of the Cricket Mountains block. In addition, in the area of the buried Cricket Mountains block itself, the persistent relation of onlapping basin fill 
against the east-dipping edges of the Cricket Mountains block, described above, identifies the boundary between Tertiary basin fill and older rocks. Using these relations, we have assembled a structural contour map of the Paleozoic-Tertiary contact (fig. 10) for the Sevier Desert area as a whole.

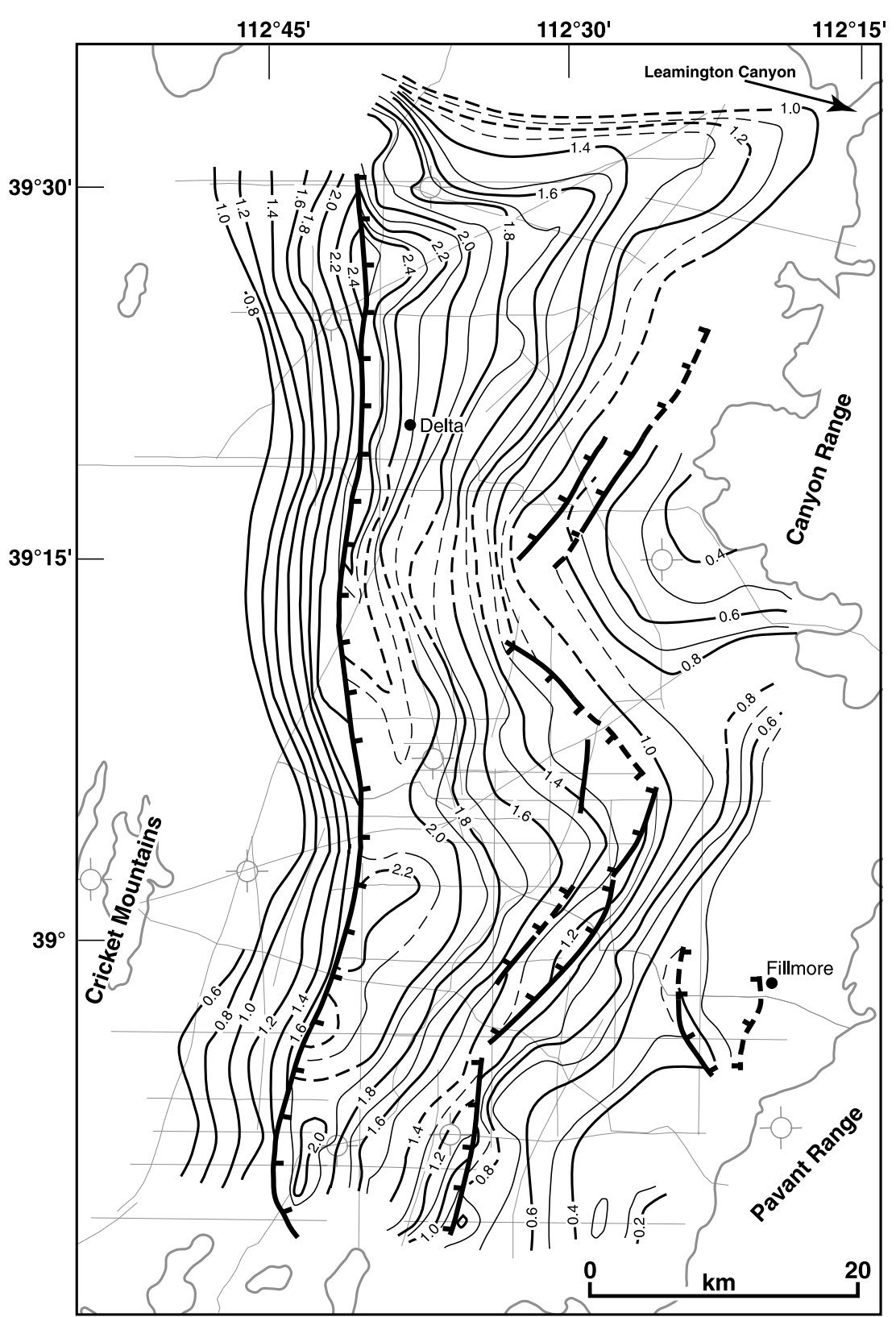

Fig. 10. Structural contour map of Paleozoic-Tertiary contact, Sevier Desert basin. Contours are in seconds of two-way travel time. Constraining wells and seismic profiles are shown in outline; see figure 1. 
The map marks out the Sevier Desert basin as an elongate, $30 \mathrm{~km}$ by $85 \mathrm{~km}$ oval, with substantial irregularities, in plan view. The basin divides naturally into two large, oval subbasins, one in the north and one in the south, separated by a saddle-like intrabasin high roughly $12 \mathrm{~km}$ south of Delta (although a near-complete data gap in the area precludes determination of the exact position and shape of the intrabasin high). At its deepest point, the depocenter of the northern subbasin, located $7.5 \mathrm{~km}$ northwest of Delta, contains approximately $4000 \mathrm{~m}$ (assuming a mean seismic velocity of $\sim 3200 \mathrm{~m} / \mathrm{s}$; Anders and others, 1995) or more (Mitchell and McDonald, 1987) of Cenozoic fill. The southern depocenter, $30 \mathrm{~km}$ west-northwest of Fillmore, is shallower, with some $3500 \mathrm{~m}$ of infill at its deepest point.

This north-south asymmetry complements the substantial east-west asymmetry revealed in dip-oriented seismic profiles and noted by previous researchers (Allmendinger and others, 1983; Von Tish and others, 1985; Mitchell and McDonald, 1987; Planke, ms, 1987; Coogan and DeCelles, 1996), and constitutes an important firstorder attribute of the basin. As noted above, east-west lines such as the well-known COCORP profile shot in the early 1980s (Allmendinger and others, 1983) show a reflection that dips at a low angle to the west and then abruptly shallows at the westward limits of the basin, above the Cricket Mountains block. The portion of the reflection east of the Cricket Mountains block has a strong, multi-cycle and quasicontinuous character on numerous profiles, and has been labeled the Sevier Desert detachment (Allmendinger and others, 1983; Von Tish and others, 1985; Mitchell and McDonald, 1987; Planke, ms, 1987; Planke and Smith, 1991; Royse, 1993) or the Sevier Desert reflection (Anders and Christie-Blick, 1994; Coogan and DeCelles, 1996). In this paper, we refer to it simply as the basal Tertiary reflection or the Paleozoic-Tertiary contact, labels borne out by data from intrabasin wells. Although previous workers have stressed the apparent continuity of the reflection in the seismic data, several profiles suggest that the reflection may be broken by normal faults of small offset (fig. 10); these faults, however, are insufficient to create significant space in the basin.

A particularly notable feature of the map is an elongate trough, running ENE to WSW across the width of the northern basin, at approximately latitude $39^{\circ} 30^{\prime}$. The depression stretches from Leamington Canyon, north of the Canyon Range, to the northern depocenter of the Sevier Desert basin. A suggestion of the trough appears both on gravity maps (Bankey and Cook, 1989) and, to some extent, on the structural contour and isopach maps presented by Planke (ms, 1987, fig. 9) and Mitchell and McDonald (1987, fig. 3). The map that we present here, which is constrained additionally by data from seismic profile UHR-2 (Coogan and DeCelles, 1996) and from the previously unavailable profile SEI-2NX, suggests that the trough is a somewhat sharper feature resembling a broad drainage. The interpreted "mouth" of this drainage-like trough corresponds closely to the present area of Leamington Canyon, where the west-flowing Sevier River enters the Sevier Desert basin.

Finally, seismic data from the northern edge of the basin (Wills, ms, 2000) strongly suggest that the basin shallows abruptly north of seismic line GSI-15. Such an interpretation generally accords with the presence of a broad gravity high west of the Gilson Mountains, immediately north of the Sevier Desert basin (Bankey and Cook, 1989).

\section{Geometry of Mesozoic Thrust Faults}

Arguments regarding the existence and slip magnitude of the Sevier Desert detachment have hinged largely on assumptions about the geometry of Mesozoic-aged thrust faults, and in particular on hypothesized thrust-fault cutoffs in the detachment hanging wall (Von Tish and others, 1985). Previously unavailable industry seismic and well data place new constraints on the geometry of these thrust faults, and suggest that in the southern Sevier Desert basin, the faults are erosionally truncated by the 
Paleozoic-Tertiary unconformity in the Cricket Mountains block across a wide area, rather than being cut off by the hypothesized detachment fault.

Subsurface distribution of pre-Mesozoic rocks and Mesozoic thrusts from well data.-Two industry wells, CA and CBR, penetrated thick pre-Mesozoic successions in the area of the Cricket Mountains, west of the central Sevier Desert basin. The succession in CA has generally been interpreted as thrust-stacked Lower Paleozoic strata above the Canyon Range thrust (Mitchell and McDonald, 1987). We reinterpret that succession as including approximately $450 \mathrm{~m}(1475 \mathrm{ft})$ of upper Neoproterozoic strata, thrust atop Lower Cambrian rocks on a surface correlative with the Canyon Range thrust at a

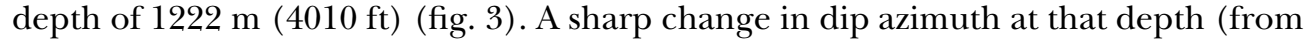
the processed dipmeter survey) suggests the presence of a fault, and an upper Neoproterozoic position for the hanging-wall rocks is both lithologically plausible and consistent, in terms of stratal thickness, with outcroppings of Lower Cambrian Prospect Mountain Quartzite that have been mapped at higher elevations in the Cricket Mountains immediately west of the hole. Two additional thrust faults, likely representing splays of the Pavant thrust, place older Cambrian on younger Cambrian strata deeper in the well.

The CBR well sampled more than $5 \mathrm{~km}$ of nearly uninterrupted siliciclastic rock that for the most part differs profoundly from the Paleozoic section, which in this area is dominated by carbonate strata. We interpret the upper $3980 \mathrm{~m}(13,060 \mathrm{ft})$ of that section as Neoproterozoic rock, based on its close similarity in lithology and stratigraphic succession with the Neoproterozoic rocks described in surrounding areas by previous researchers (Crittenden and others, 1971; Dommer, 1980; Christie-Blick, 1982; Millard, 1983; Holladay, 1984; Hintze, 1984). These rocks sit in apparent thrust contact atop Lower Cambrian strata; based on that relationship and on close lithologic similarities of the rocks beneath the hypothesized thrust surface in the two wells, we interpret this thrust in CBR as the Canyon Range thrust and as correlative with the uppermost thrust penetrated by CA. The second-highest thrust in the CA well is interpreted to correlate with a deeper thrust in CBR (fig. 3).

Four of the five intrabasin wells-AE, APB, AHR, and AMF-bottom in Paleozoic strata. (GG did not reach pre-Tertiary rocks.) The four wells apparently sampled different parts of the section, however. Mitchell and McDonald (1987) favored a Siluro-Devonian age for the gray, sucrosic dolomites at the bottom of AE. By contrast, the APB and AHR wells, in the central and southern basins, apparently bottom in Cambrian rocks. APB sampled shale and quartzite intervals generally interpreted as basal Cambrian (Planke, ms, 1987), and similar to rocks that we have interpreted as lying above the Pavant thrust in the CA well to the west (fig. 3). AHR penetrated rocks of likely Middle Cambrian to Late Cambrian age, which can be plausibly correlated, based on lithologic similarity and neutron-density log patterns, with strata interpreted as lying below the Pavant thrust in the CA well. These subsurface relations suggest one of two possibilities. If the AE, APB, and AHR wells all occupy the same thrust plate, the sub-Tertiary rocks of the basin may form a broad, east-west-trending anticline. Alternatively, strata below the basin fill that are sampled by the different wells may occupy parts of different thrust plates.

On the eastern basin margin, the SSC well, in the southwest Pavant Range, is generally interpreted as comprising an uninterrupted section from the Triassic through the Ordovician, though Villien and Kligfield (1986) suggest a possible Ordovician-onDevonian thrust at approximately $2520 \mathrm{~m}(8268 \mathrm{ft})$ depth. The pre-Mesozoic strata sampled by the PH well, approximately $43 \mathrm{~km}$ northwest of SSC and west of the Canyon Range foothills, commonly have been interpreted as entirely Early Paleozoic in age, either as uninterrupted section (Mitchell and McDonald, 1987) or as a thrust-stacked succession of Lower Paleozoic rocks (Coogan and others, 1995, as shown in DeCelles 
and others, 1995, and Mitra and Sussman, 1997). Wills (ms, 2000, appendix B), in a reanalysis of the sample logs and geophysical data from the well, tentatively reinterpreted these strata as all Siluro-Devonian or younger in age, based on lithologic and stratigraphic similarity with successions described elsewhere in the region (Davis, 1983; George, 1985; Hintze, 1993).

Pavant thrust geometry from well and seismic data.-Our interpretation of the CA industry well (fig. 3) holds that the well passed through three Mesozoic thrusts: the

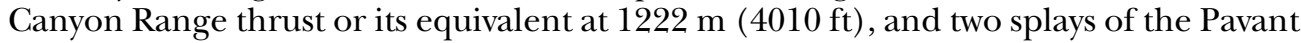
thrust at $2295 \mathrm{~m}(7530 \mathrm{ft})$ and $2551 \mathrm{~m}(8370 \mathrm{ft})$. The well site is directly crossed by seismic profile PC-2 (McDonald, 1976) and can be tied to that record with a synthetic seismogram (fig. 11). Although the PC-2 record is not unambiguous, these contacts can be carried with some confidence to strike lines SEI-2 and V-12, which allow reflections related to these surfaces to be tied to other area seismic profiles and mapped across the southern Sevier Desert (fig. 12).

Especially prominent in southern-basin industry data are two high-amplitude, parallel reflections imaged at depth in the Cricket Mountains block (for example, figs. 7 and 8; also see Planke and Smith, 1991, and Mitchell and McDonald, 1987). The lowermost of the reflections, interpreted on line PC-20 (not shown here) by Mitchell and McDonald (1987) as a thrust fault not penetrated by the CA well, can be tied using newly available data directly to a zone of high impedance contrast in that well that we interpretbased on the synthetic seismogram tie (fig. 11) and the similarity of the stratigraphic succession to the Lower Paleozoic succession exposed in nearby exposures, especially in the House Range (Hintze, 1993) — not as a thrust fault but as a regionally extensive Middle Cambrian shale unit ("Whirlwind Fm" on fig. 11) sandwiched between two dense Cambrian limestone units. The upper reflection ties to a horizon in the CA well interpreted as a thrust fault that places older Cambrian rocks atop younger Cambrian and that we identify as the Pavant thrust. The thrust marks out a persistent, highamplitude reflection in seismic data that can be mapped as a northeast-striking, northwest-dipping surface, folded into a doubly plunging antiform in the central basin (fig. 12A). The trend of the thrust closely follows the grain of exposed Paleozoic and Neoproterozoic rocks in the Cricket Mountains (Hintze, 1980). For the most part, the seismic surface corresponding to the Pavant thrust is erosionally truncated by the Paleozoic-Tertiary unconformity of the Cricket Mountains block, although in some areas it may be cut off by high-angle normal faults at the basin margin.

A second thrust fault placing older Cambrian on younger Cambrian was sampled at $2295 \mathrm{~m}(7530 \mathrm{ft})$ in the CA well. This thrust, more poorly imaged than the deeper one, appears to be relatively local in extent; strike line V-12 (fig. 13) strongly suggests that it merges with the deeper Pavant thrust approximately $8 \mathrm{~km}$ south of the CA well. The strata above the shallower thrust were also likely sampled in the CBR well, approximately $11 \mathrm{~km}$ west-northwest of the CA well (fig. 3). As with the deeper thrust, we interpret this shallower one to be erosionally truncated by the Paleozoic-Tertiary unconformity of the Cricket Mountains block.

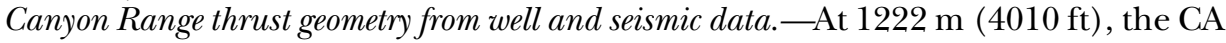
well penetrated a contact placing predominantly siliciclastic, probable Neoproterozoic rocks atop carbonate rocks. We interpret this contact, which corresponds to an orientation change on the dipmeter record, to be the Canyon Range thrust or its equivalent. A similar contact, placing a much thicker, predominantly Neoproterozoic section atop Cambrian rocks, was observed in the CBR hole at $4206 \mathrm{~m}$ (13,800 ft). Thus the Canyon Range thrust appears to shallow approximately $3 \mathrm{~km}$ from the CBR well to the CA hole.

The Canyon Range thrust is poorly imaged on most southern Sevier Desert seismic profiles, and detailed contouring based on available seismic data is not possible 


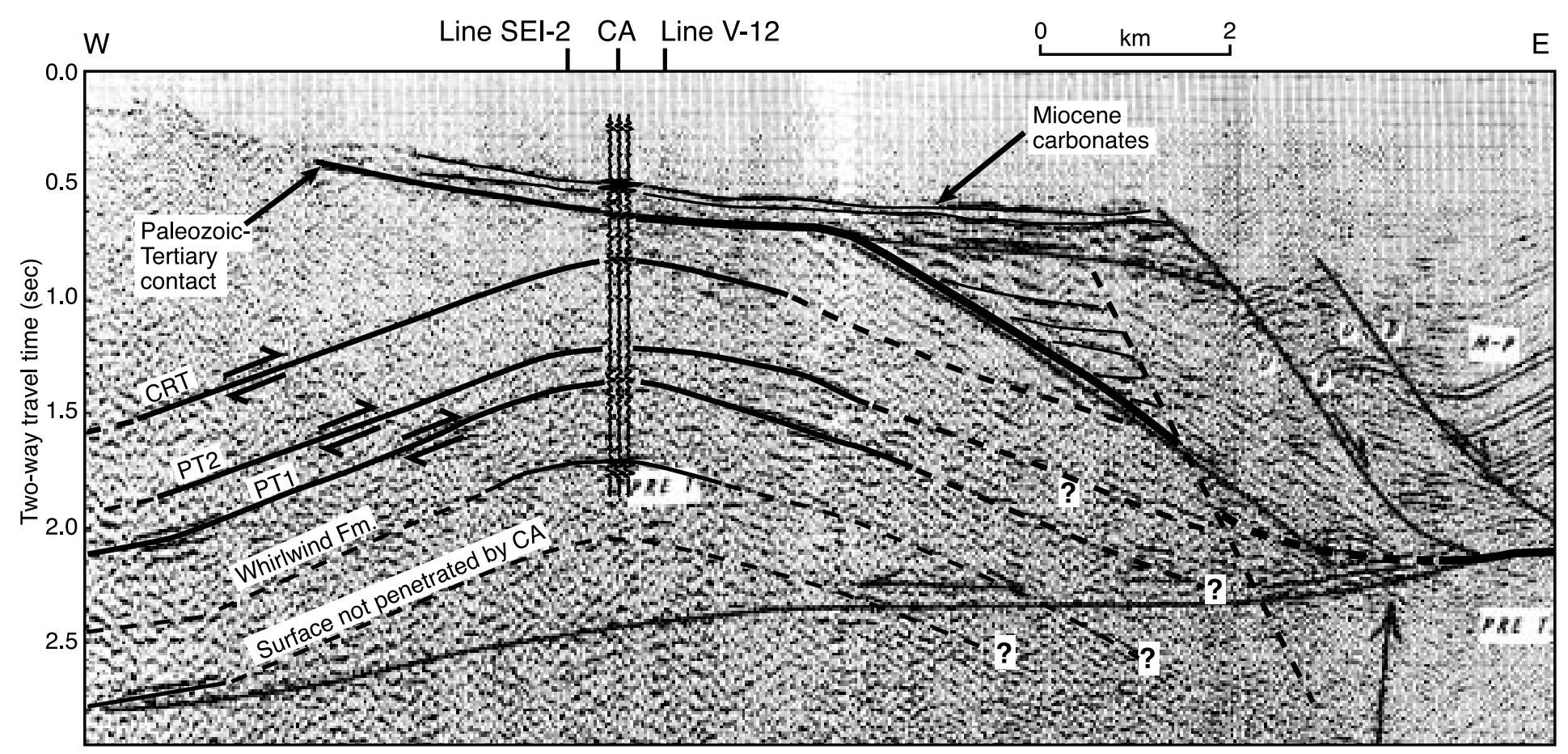

E

11. Detail of well. Interpretations that are either thin lines or lines that are partially dashed are those of
with inclined script are from McDonald (1976) and all other captions are from this study. 

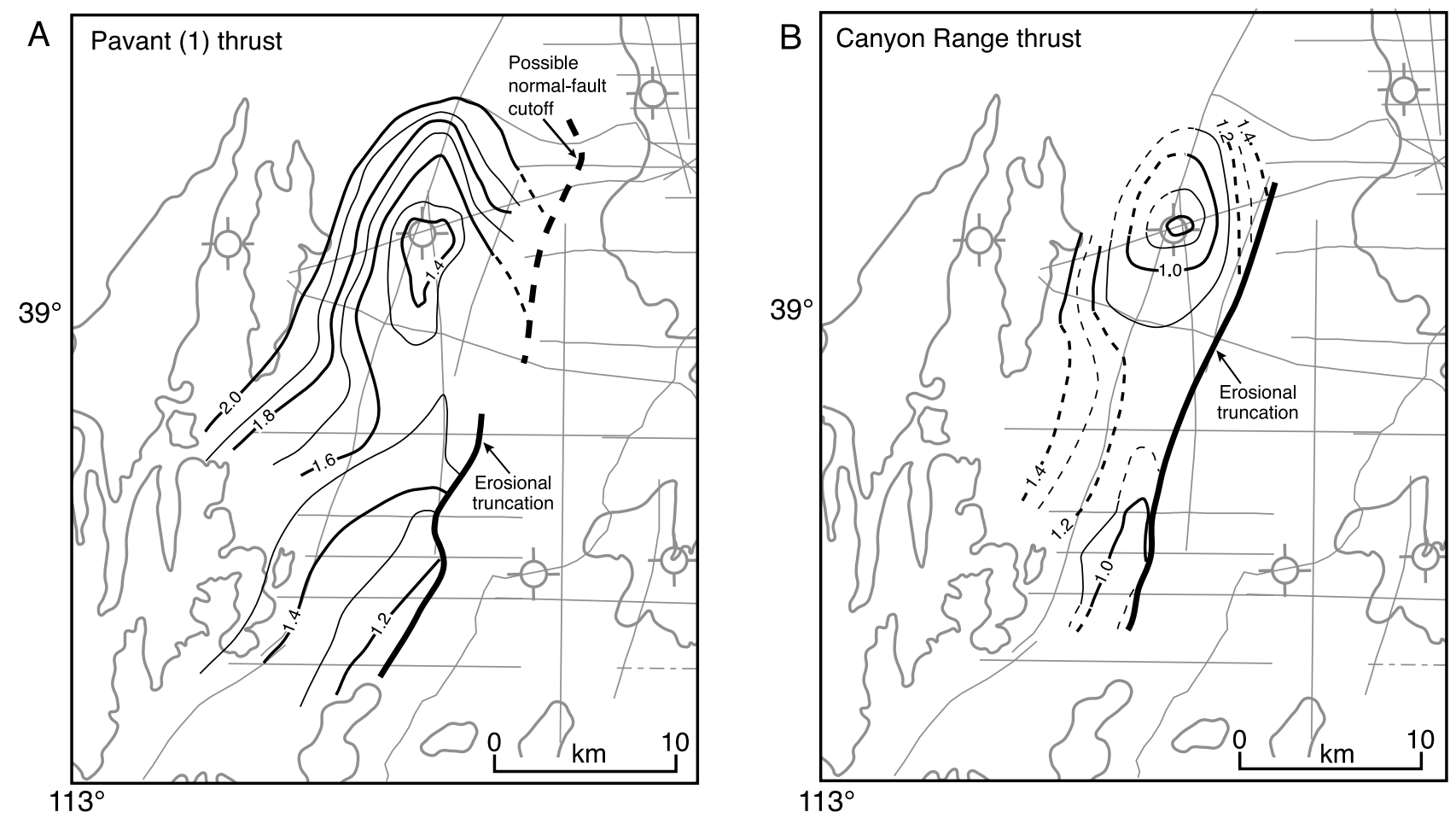

Fig. 12. Structural contour map of Mesozoic thrust faults, Cricket Mountains block, from seismic reflection profiles and well data (area of map shown in figure 1). Contours are in seconds of two-way travel time. (A) Main Pavant thrust fault. (B) Interpretive contour map of Canyon Range thrust fault. See text for details. 
S

Line V-11

Line PC-20

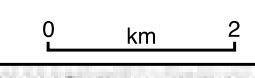

Line SEI-
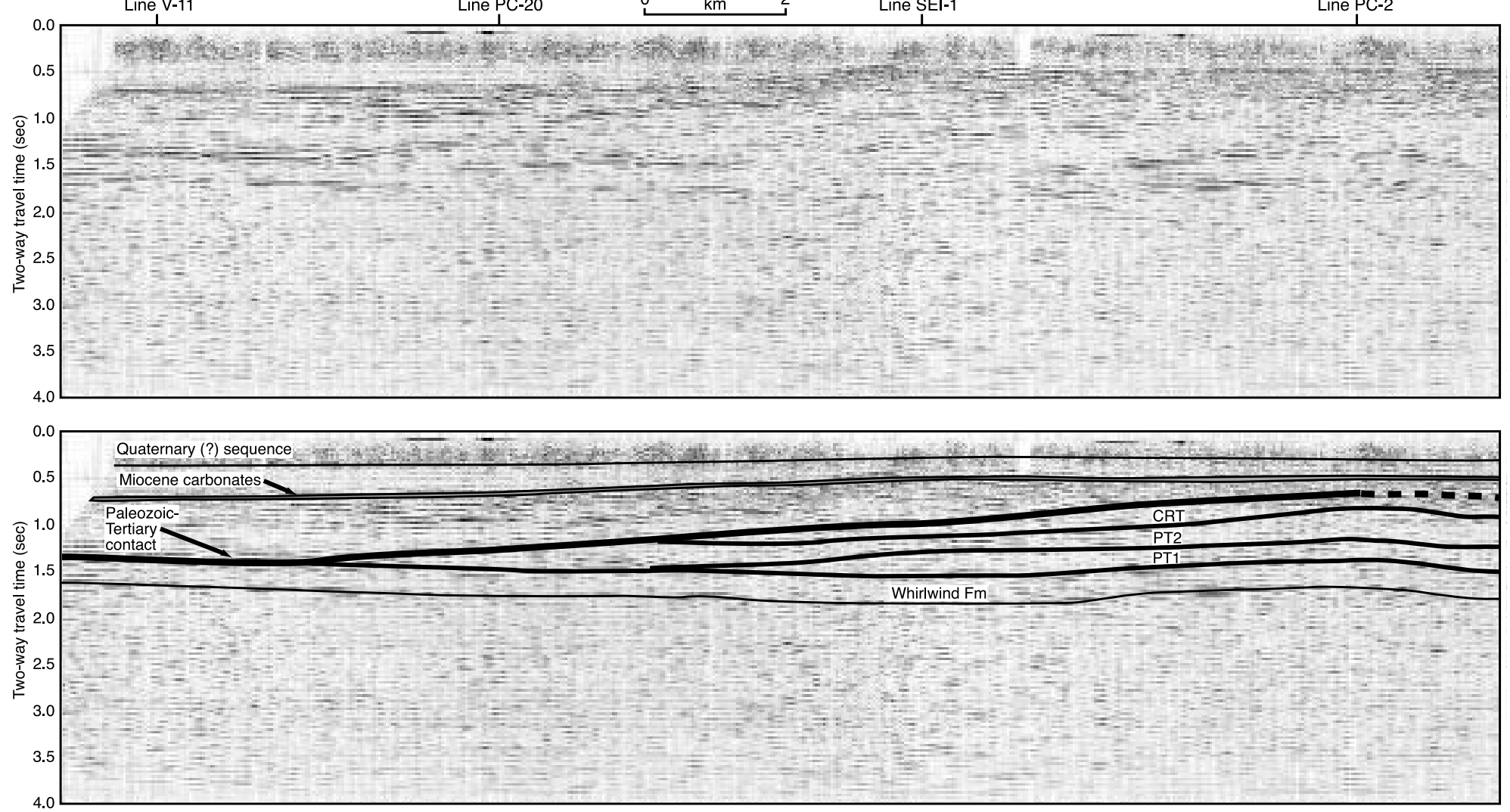

Fig. 13. Strike line V-12, showing subsurface relations of Canyon Range thrust and possible splaying of Pavant thrust in the Cricket Mountains block and erosional truncation of the Canyon Range thrust against the Paleozoic-Tertiary unconformity, southern Sevier Desert area. Seismic data provided by Vastar Resources, Inc.; interpretation is that of the authors. 
as it is with the main Pavant thrust. We present an interpretive contour map of the surface (fig. 12B), assuming that the Canyon Range thrust occupies the same stratigraphic horizon in Lower Cambrian carbonates throughout the Cricket Mountains area, as is suggested by the record of the CA and CBR wells, and that topography on the thrust is the result of uplift and folding by younger, deeper thrust faults. This interpretation, if correct, suggests that the Canyon Range thrust is erosionally truncated at the Paleozoic-Tertiary unconformity throughout the Cricket Mountains block in the southern Sevier Desert. The interpretation presented here also implies that approximately $2.4 \mathrm{~km}$ of Neoproterozoic strata are cut out of the hanging wall of the Canyon Range thrust in the $11 \mathrm{~km}$ between the CBR well and the CA well, which suggests the possibility of substantial fault-bend folding related to that stratal truncation within the Cricket Mountains block.

\section{Possible High-Angle Basin-Bounding Structures}

Mitchell and McDonald (1987) asserted that no evidence exists for high-angle normal faults bounding the western or eastern edges of the Sevier Desert basin, and that previous interpretations attributing the basin's genesis to high-angle, basin-rangetype faulting are thus incorrect. Our analysis of seismic reflection data from the basin suggests the existence of a number of previously unrecognized high-angle structures of varying ages that may offset the Paleozoic-Tertiary boundary at or near both sides of the basin. Offsets on these faults are too small to explain all sedimentary accommodation within the basin, but may explain some of the late Tertiary subsidence.

Eastern basin-bounding structures.-Seismic data from the southern Sevier Desert basin (figs. 10 and 14) suggest the presence of a persistent series of high-angle normal faults offsetting the Paleozoic-Tertiary boundary near the basin's eastern margins. Offsets of the boundary vary along the strike of the faults from near zero to as much as $450 \mathrm{~m}$ (assuming an average seismic velocity of $3000 \mathrm{~m} / \mathrm{s}$ for the Tertiary basin fill). The actual total offsets on the faults, however, are difficult to determine, as some of the data suggest that the upthrown block may have marked a surface of erosion after faulting. Further north in the basin data are sparser, but some structures visible on seismic data do seem to cut the Paleozoic-Tertiary unconformity here as well. Particularly important are two faults with 375 m offset imaged in COCORP Utah Line 1 that correspond to similar structures in line GSI-20 and that Wills (ms, 2000) interpreted as high-angle normal faults at the margins of the Canyon Range gravity high. Data further north do not cover the area of these faults, however, so continuing them along the Canyon Range is speculative. Smithson and Johnson (1989) have concluded, on the basis of seismic-velocity modeling, that the actual throw on these faults may be approximately $500 \mathrm{~m}$, greater than the $375 \mathrm{~m}$ of displacement interpreted by Wills $(\mathrm{ms}$, 2000). The trend of the faults mapped in the eastern Sevier Desert (fig. 10) generally parallels that of a set of offsets mapped in the Quaternary basalts of the Black Rock Desert area, in the central part of the basin (Hintze, 1980; Oviatt, 1989, 1991), and of the contours of the basal Tertiary reflection within the basin itself.

Western basin-bounding structures.-Line SEI-4 (fig. 15) shows a pattern of growth strata in the upper 0.9 seconds of the record that is consistent with syntectonic deposition in the hanging wall of a high-angle normal fault at the southwestern edges of the basin. The Paleozoic-Tertiary boundary within the basin-extended from industry well AHR, which is directly crossed by the line-apparently terminates against this high-angle fault, and the growth strata related to the hypothesized fault can be tied to similar strata imaged on line V-5 (fig. 9). We suggest that the high-angle structure imaged on these lines constitutes a segment of a larger, late-stage high-angle normal fault, in the southwest part of the basin, that is also crossed by lines V-7 and V-11 (fig. 7). The high-angle fault appears to cut off the listric normal faults identified by Planke (ms, 1987), and likely was active after the mid-Miocene, as it cuts a set of reflections 

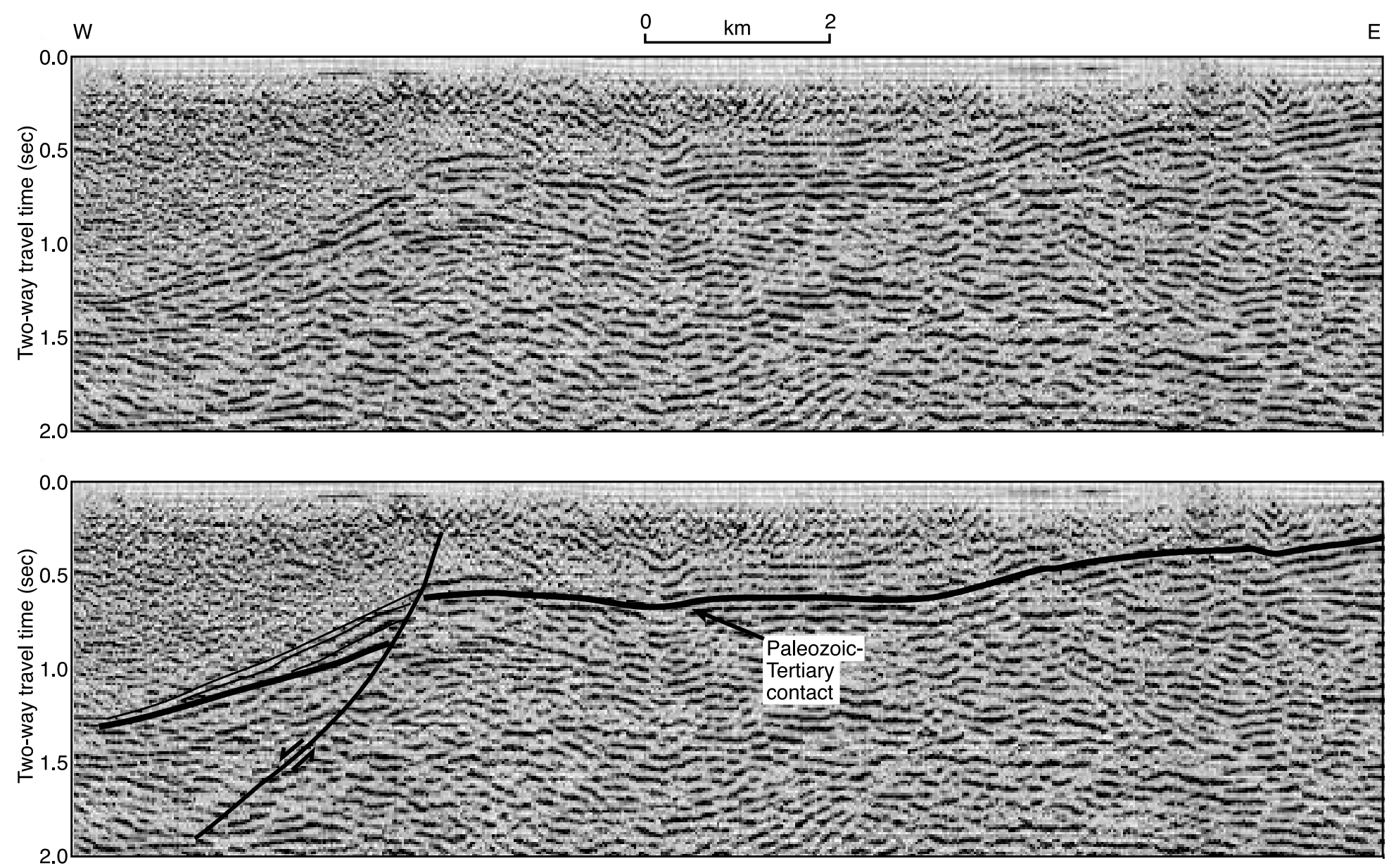

Fig. 14. Seismic line V-3, showing high-angle normal fault bounding eastern Sevier Desert basin. Seismic data provided by Vastar Resources, Inc.; interpretation is that of the authors. 


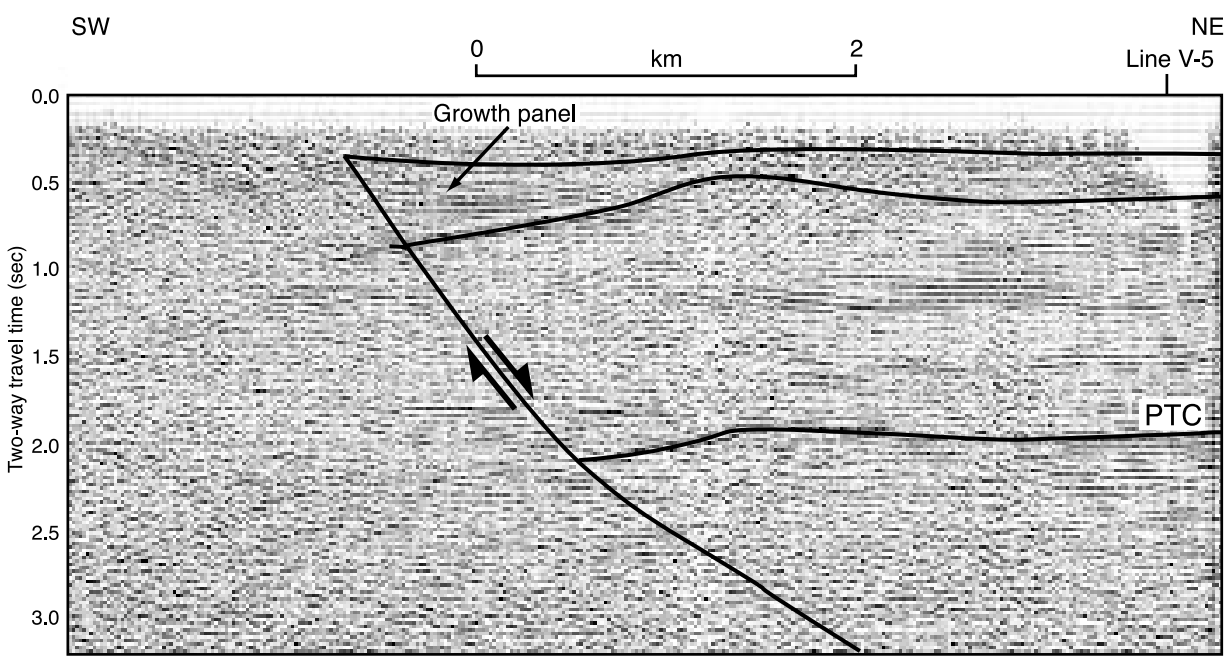

Fig. 15. Detail of line SEI-4, showing extension of line past area covered by line GSI-11, published by Mitchell and McDonald (1987) (see fig. 1). The profile shows a high-angle normal fault that can be tied to basin-bounding structures on dip lines in the southern Sevier Desert basin. PTC is Paleozoic-Tertiary contact in basin. Seismic data provided by Seismic Exchange, Inc.; interpretation is that of the authors.

that can be tied to carbonates dated at mid-Miocene that were sampled by the CA industry well (Crone and Harding, 1984). The maximum interpreted offset of this fault is $750 \mathrm{~m}$, assuming an average velocity of $2500 \mathrm{~m} / \mathrm{s}$ for the Cenozoic basin fill.

Previously unavailable seismic profile SEI-1 suggests the presence of another relatively planar, high-angle fault that offsets reflections associated with the PaleozoicTertiary boundary, the Pavant thrust, and Middle Cambrian strata (fig. 16). The offset on this feature, as interpreted, is likely on the order of $500 \mathrm{~m}$. Five features of this image merit particular attention: (1) the abrupt termination of tabular reflections beneath the Paleozoic-Tertiary unconformity against the inferred fault; (2) apparent

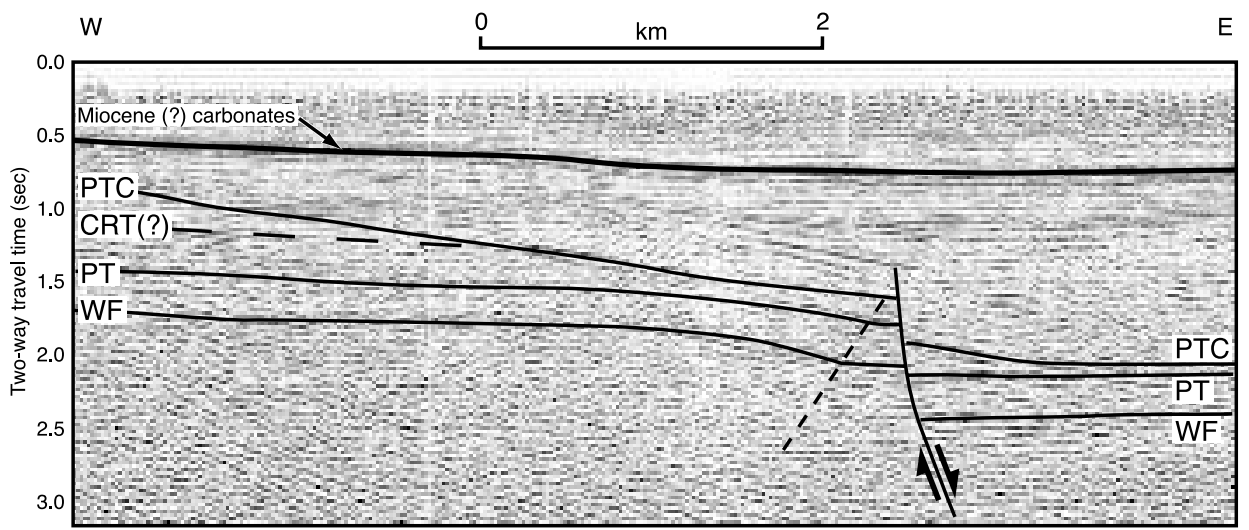

Fig. 16. Detail of line SEI-1, showing high-angle fault. The high-angle fault offsets reflections that we identify with Mesozoic thrusts and Paleozoic sedimentary units, and does not offset a reflection that we tie with carbonate strata for which a Miocene date was cited by Crone and Harding (1984). Seismic data provided by Seismic Exchange, Inc.; interpretation is that of the authors. 
offset of the Paleozoic-Tertiary unconformity itself; (3) truncation of east-tilted reflections within 0.25 seconds two-way travel time above the Paleozoic-Tertiary contact in the footwall of the inferred fault; (4) onlap of higher strata against these inclined reflections; and (5) continuity of strata, including reflections interpreted as the Miocene carbonate unit sampled by the CA well, above the inferred fault, which suggests that offset on the fault had concluded before the mid-Miocene. The trace of this fault is apparently collinear with the trace of the high-angle basin-bounding structure interpreted on seismic profiles further to the south in the basin. As noted above, that fault is likely mid-Miocene or younger, as it cuts Miocene-aged carbonates apparently not offset by the fault in the central basin. It is thus possible that the fault identified on SEI-1 and the fault mapped based on lines to the south represent the same structure, but that the segment in the north was active earlier than the one in the south.

Evidence for western basin-bounding faults in the northern Sevier Desert is comparatively limited, although small disruptions in the strong basal Tertiary reflection can be seen at the eastern edges of the Cricket Mountains block on COCORP Utah Line 1 and on several industry lines. Offsets along these possible high-angle structures cannot be quantified in the absence of piercing points. The structures, however, appear to be of small displacement and likely played only a minor role in creating sedimentary accommodation.

DISCUSSION

In this section, we approach the Sevier Desert data from two perspectives. First, we discuss new constraints that the data and interpretations presented here place on the timing and kinematics of rooted-detachment models for the Sevier Desert basin. And, second, we present a number of observations from the subsurface data that may be incompatible with a detachment model.

\section{The Detachment Model in Light of the New Data}

Age of basin and initiation of detachment motion.-In the broadest sense, the data presented here highlight how little is known about the age of the Sevier Desert basin and the timing of events that led to its present-day morphology. Notwithstanding nearly a quarter-century's work in the area by many researchers, the timing of the basin's tectonic genesis continues to hang principally on two dates from a single, forty-year-old industry well, the GG hole (McDonald, 1976; Lindsey and others, 1981; Von Tish and others, 1985; Coogan and DeCelles, 1996), and, to lesser extent, on a Miocene age cited by Crone and Harding (1984) for a carbonate unit in the CA well. The published age record of other important intrabasin wells such as AE, APB, AHR, and AMF is qualitative, poorly documented, and in some cases internally inconsistent, as is reviewed by Mitchell and McDonald (1987). Recently published zircon and apatite fission-track ages from the basin margins (Allmendinger and Royse, 1995; Stockli and Linn, 1996; Stockli and others, 2001) are subject to multiple interpretations and bear no clear relationship to the known ages of the older strata in the basin (Wills and Anders, 1999; Wills, ms, 2000).

From the poorly constrained surface and subsurface dates, it follows that the timing of initial movement on the hypothesized detachment remains an open question. Estimates for the onset of detachment motion range from mid-Eocene or earlier (Mitchell and McDonald, 1987; Chase and others, 1998) to Oligocene or later (Von Tish and others, 1985; Planke, ms, 1987), and tend to hinge on how the inadequately logged GG hole is tied with nearby seismic profiles. While additional work with existing industry well samples could yield new insights, a clear need exists for continuous core in both the northern and southern basins to resolve questions regarding the age of the basin and to provide constraints on the timing of detachment faulting. 
Cessation of detachment motion in central and southern basin.-Although the data presented here have little to say about when detachment motion may have started, they do shed light on when it may have ended in the central and southern basin. We have attempted to show that, although the Paleozoic-Tertiary contact within the basin does indeed seem to be largely uncut by high-angle normal faults, it is not entirely uncut by such faults. In particular, the seismic data strongly suggest the presence of high-angle normal faults on both the eastern and western sides of the basin. One such fault (fig. 16) offsets surfaces that apparently correspond to Mesozoic-aged thrust faults and Paleogene basin fill-and, thus, the hypothesized detachment surface as well-but does not cut a prominent reflection that we have tied to a carbonate unit penetrated by the CA well. Motion on the hypothesized detachment thus must have ceased by the time this unit was deposited, at least in the central and southern Sevier Desert basin. Crone and Harding (1984) assigned this unit a Miocene age, based on oil company records, but the quantitative analyses supporting that date are unavailable (Anthony J. Crone, personal communication, 2003). We have used the Miocene date for this unit in our interpretations, though we recognize the need for better quantitative support for that date.

Estimates of total offset from Mesozoic structure.-One commonly cited method of estimating slip on the Sevier Desert detachment lies in offsets of presumed Mesozoic thrust-fault cutoffs along the inferred low-angle normal fault. Sharp (ms, 1984) and Von Tish and others (1985) estimated detachment offset at 28-38 km based on restoration of presumed thrust cutoffs. Coogan and DeCelles (1996) maintained that some $39 \mathrm{~km}$ of detachment slip "is required to restore presently extended parts of the stratigraphically distinct Canyon Range and Pavant thrust sheets across the Sevier Desert basin." This study helps to illuminate these estimates as well, by adding new seismic reflection coverage and the record of a previously undescribed industry well-and, as a result, by providing a higher-resolution picture of the Mesozoic thrust geometry in the southern Sevier Desert area. As important, perhaps, the study allows an enhanced appreciation of the comparative lack of similar constraining data in the northern basin, the source of most of the "piercing-point" estimates for total detachment slip.

The new seismic and well data plausibly relate several seismically imaged surfaces in the Cricket Mountains block to the Canyon Range and Pavant thrust faults, and allow contouring of those surfaces over a relatively wide area of the southern basin (fig. 12). These surfaces strike generally northeast, and ramp up substantially between the CBR and CA industry wells. Although the record in a few profiles is ambiguous, in the vast majority of southern industry data these two thrusts do not appear cut off against any inferred detachment surface in the hanging-wall block, but instead are erosionally truncated or terminate against basin-bounding high-angle normal faults.

These observations carry potential significance. The assumption that the Canyon Range thrust, the Pavant thrust, or both surfaces are cut off by the putative detachment fault is central to many quantitative estimates of fault offset. No well control for the hypothesized hanging-wall block exists in the northern basin, and we are aware of no published seismic reflection data that tie known thrust reflections in the southern basin with their counterparts in the north. The northern thrust geometry in earlier studies derives entirely from sparse seismic data (in particular the COCORP line) and from the projected record of the CA well in the southern basin (see, for example, Von Tish and others, 1985). The generally northeast strike of major Mesozoic structures in the southern subsurface, however, suggests that simple northward projection of CA may lead to interpretive errors.

Alternative interpretations of the northwest basin-margin data are possible. One such model involves truncation of the Canyon Range thrust against the Paleozoic- 
Tertiary unconformity in the Cricket Mountains block in the north (fig. 17), as seems to be suggested by the southern data. That interpretation, if correct, means that the offset of the detachment fault is essentially unconstrained by piercing points, and that even under a detachment model, the data may permit substantially lower totalextension estimates (for example, the $\sim 6 \mathrm{~km}$ of Planke, ms, 1987) than the nearly 40 $\mathrm{km}$ of slip envisaged by Von Tish and others (1985) and Coogan and DeCelles (1996).

Implications for thrust-reactivation models. - The thrust geometry developed here also argues against models, such as that of Mitchell and McDonald (1987), that view the
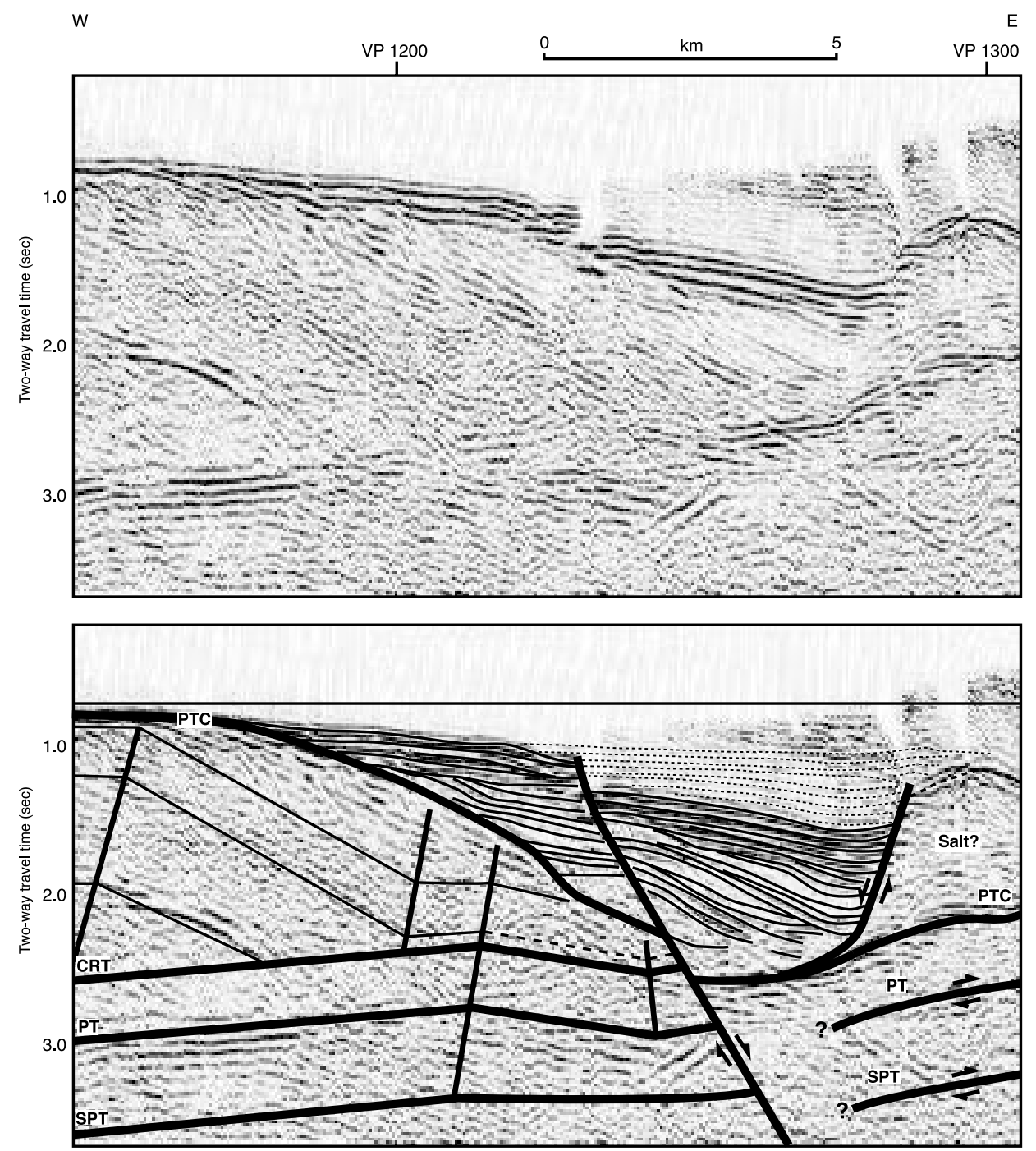

Fig. 17. Reinterpretation of a section of COCORP Utah Line 1, originally published and interpreted by Allmendinger and others (1983). Canyon Range thrust (CRT) is not cut off against a hypothesized detachment fault in this illustration, but is erosionally truncated (in a block downdropped by late-stage high-angle normal faulting), and thus provides no piercing point for estimating total slip on the hypothesized Sevier Desert detachment. Pattern of sedimentary layers above Paleozoic-Tertiary contact (PTC) is attributed to withdrawal of early-deposited salt and re-emplacement into adjacent salt structure. PT - Pavant thrust; SPT - sub-Pavant thrust. See text for details. 
Sevier Desert detachment as an extensional reactivation of the Pavant thrust. Dip-line seismic profiles presented here and by Wills (ms, 2000), especially line V-5 (fig. 7) show the presence of eastward-shallowing surfaces beneath the basin floor that likely represent sub-Pavant Mesozoic thrust faults. Thus, in the dip direction, the basin floor-usually interpreted as identical to the hypothesized detachment fault-clearly cuts across the pre-existing Mesozoic grain.

These relations become even more compelling in a generalized, interpretive along-strike cross-section (fig. 18). The cross-section, constrained by the three wells in the deepest part of the basin and by a number of available seismic profiles, has two attributes of particular note. First, the basin floor shows substantial topography, including local depressions coincident with east-west, drainage-like troughs (fig. 10). Second, surfaces interpreted to correspond to Mesozoic thrust faults apparently shallow to the south within the basin. In particular, a surface interpreted as a Mesozoic thrust that lies beneath the bottom-hole strata of the APB well is interpreted to be truncated somewhere south of that well by the Paleozoic-Tertiary contact in the basin. The Paleozoic rocks tested by the AHR well, further south, are of younger Cambrian age than the strata sampled in APB and are thus interpreted to lie in a deeper thrust plate. There is no evidence on any seismic profiles of which we are aware that the interpreted thrust immediately below APB changes orientation and deepens south of the well, which would be required if the strata in the two wells occupied the same thrust plate.

A

$S$
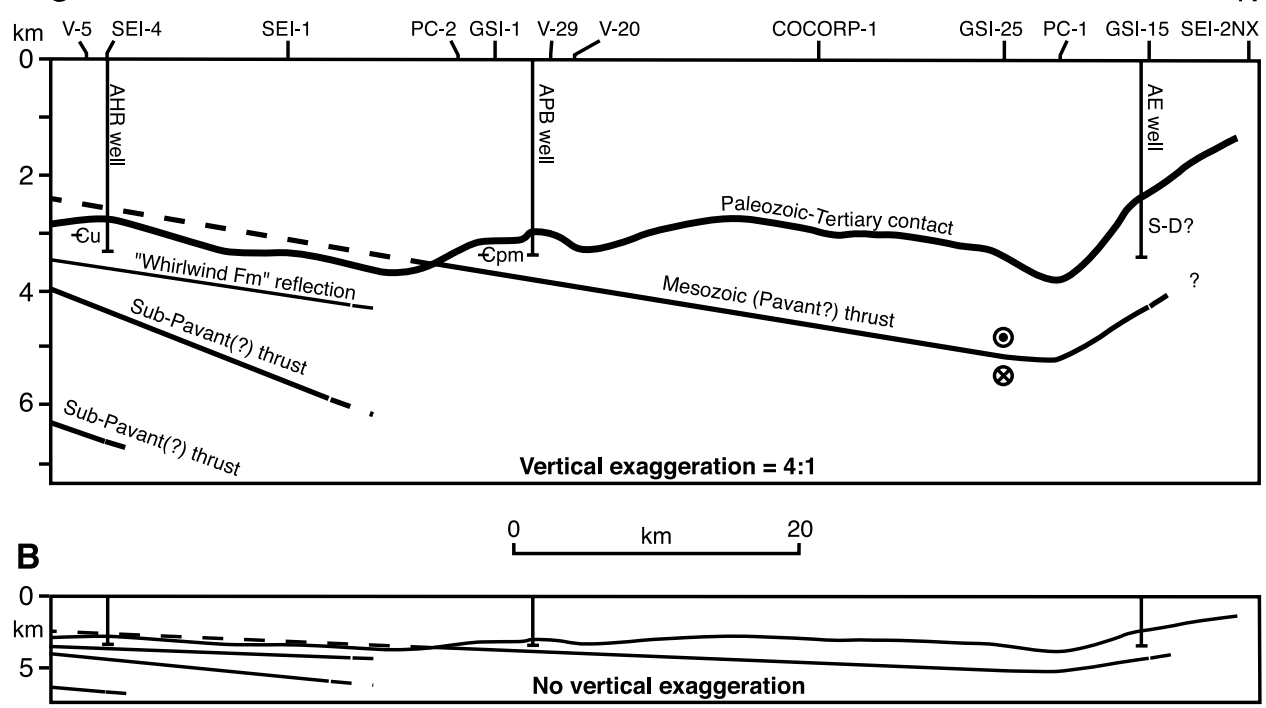

Fig. 18. Schematic north-south (along-strike) cross-section, Sevier Desert basin, shown at both 4:1 vertical exaggeration and no vertical exaggeration. Interpretation is based on three industry wells (which define line of section), on seismic profiles (only a subset of which are shown), and on the contour map of the Paleozoic-Tertiary contact (fig. 10). Depth picks are based on interpolations of velocity between the three constraining wells. The section shows the substantial topography characteristic of the basin floor, and the apparent geometry of Mesozoic thrust faults along basin strike. $\mathrm{Eu}$ - undifferentiated Middle and Upper Cambrian carbonates; Epm - Lower Cambrian Prospect Mountain Formation; S-D - undifferentiated Siluro-Devonian (?) dolostones. 


\section{Potential Incompatibilities with the Detachment Model}

Correlations between "hanging wall" and "footwall" strata.-In a larger sense, the geometry outlined above points to an attribute of these data that may be incompatible with the detachment hypothesis itself. Between the extreme southern part of the Sevier Desert and the area of the CA well, the Mesozoic thrust faults and Paleozoic strata within the Cricket Mountains block (the hanging-wall block of the hypothesized detachment) as sampled by the CA well and mapped using seismic data, deepen toward the north (fig. 12). A similar trend is observed in Mesozoic thrust faults beneath the Tertiary fill within the Sevier Desert basin itself, in the footwall of the hypothesized detachment (fig. 18). The Lower Cambrian rocks sampled by APB, in the footwall of the putative detachment, can be correlated with high confidence on lithologic grounds with the rocks above the Pavant thrust sampled by the CA well, in the detachment hanging wall (fig. 3). The Middle and Upper Cambrian rocks penetrated by AHR can be correlated with equal confidence, based on lithology and on neutron/ density log patterns (Wills, ms, 2000; Appendix B), with rocks below the Pavant thrust, sampled by CA (fig. 3) and traced using seismic ties to the purported hanging-wall block in the southern Sevier Desert. Thus, both in the general trend of major Mesozoic structures and in the characteristics of individual stratal units, the rocks in the Cricket Mountains block are closely related to the rocks beneath the basin floor, and that relationship apparently persists for at least $25 \mathrm{~km}$ along strike in the southern Sevier Desert (fig. 19).

In a non-detachment model, these relations are easily resolved through restoration of a small amount of slip on the normal faults we have mapped on the western edges of the basin (fig. 19). It is more difficult to understand how these relations could be maintained along strike in a detachment model, because the basin floor, which is identified with the hypothesized detachment fault, appears to cut across the Mesozoic structure both in the east-west direction (see, for example, line V-5) - the transport direction of the hypothesized hanging-wall block-and in the north-south direction (fig. 18). This suggests that east-west motion thought to have occurred on the detachment fault would have been oblique to the regional structure and should not have preserved a persistent spatial relationship between rocks in the Cricket Mountains block (the hypothesized hanging-wall block) and the rocks beneath the basin floor (the hypothesized footwall block), a short distance away.

Possible thrust correlation between southern and northern basin.-Significant differences between seismic profiles from the northern and southern Sevier Desert basin pose an important quandary for detachment models for the basin's formation. In particular, seismic profiles north of line GSI-1 show a strong reflection at the Tertiary-Paleozoic contact in the basin that apparently extends, continuously or quasi-continuously, beneath the Cricket Mountains block, and that is highly suggestive of a through-going crustal fault. On profiles south of GSI-1, by contrast, seismic events tied to the basin-flooring reflection abruptly terminate at or a short distance beneath the Cricket Mountains block, without any apparent west-dipping continuation. Anders and ChristieBlick (1994), arguing against the detachment hypothesis, suggested a possible explanation for the differing patterns: the seismic reflection that marks the Paleozoic-Tertiary contact in the Sevier Desert basin, and that, in the northern basin, apparently continues essentially uninterrupted beneath the Cricket Mountains block and deep into the continental crust, actually consists of two unrelated segments. The eastern part, visible beneath both the northern and southern Sevier Desert basin east of the Cricket Mountains block, they interpret as an unconformable contact between Tertiary basin fill and underlying Paleozoic rocks. The western segment, imaged beneath the Cricket Mountains block only in the northern Sevier Desert basin, they view as a thrust fault of Mesozoic age, which according to Anders and Christie-Blick (1994) is "fortu- 


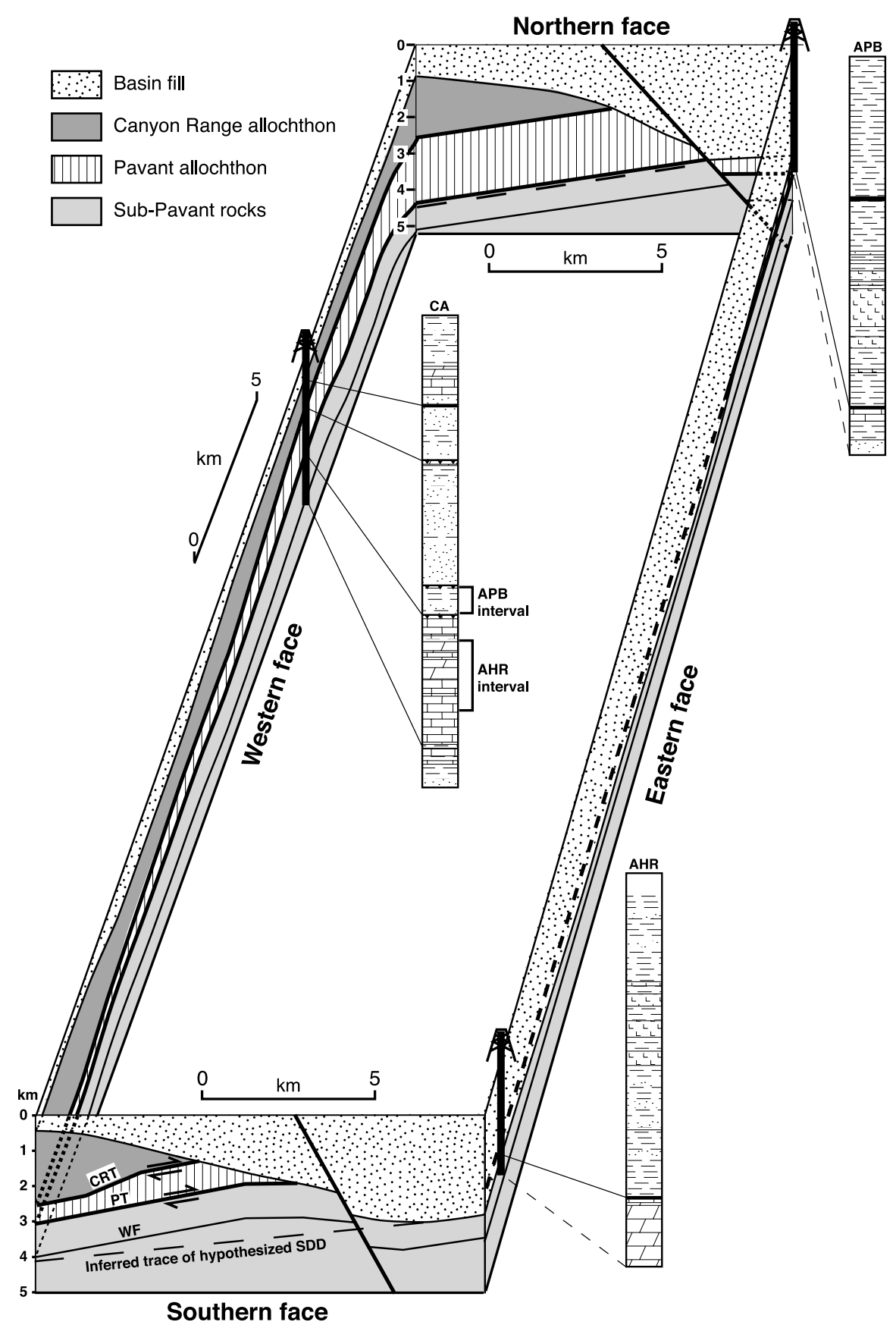

Fig. 19. Simplified fence diagram, constrained by selected data from the southern Sevier Desert basin. Western face is approximately coincident with line SEI-2 and is constrained by data from that profile and the CA well. Southern face is east-west profile at the latitude of line V-5 and is constrained by data from that profile. Eastern face is based on southern portion of schematic along-strike cross-section presented in figure 18 . Northern face is east-west profile at the latitude of the APB well and is constrained by that well and by data (projected) from line GSI-1 (Mitchell and McDonald, 1987). Major thrust surfaces and stratigraphic horizons shallow to the south both beneath the Sevier Desert basin (eastern face), in the footwall block of the hypothesized Sevier Desert detachment, and in the Cricket Mountains block (western face), in the hanging-wall block of the hypothesized detachment; moreover, well and seismic interpretations suggest that rocks in the hypothesized footwall block retain a close relationship with those in the hypothesized hanging-wall block over the area covered by this diagram. These relationships are more difficult to maintain with a large-offset detachment fault, which would have cut across regional structure in both the north-south direction (eastern face) and the east-west direction (figs. 7B and 7D). 
itously aligned" with the basal Tertiary reflection within the basin itself, and is seen as slighlty offset in COCORP line 1.

Our work with subsurface data in the southern Sevier Desert basin suggests a candidate structure for the "fortuitously aligned" thrust hypothesized by Anders and Christie-Blick (1994): the thrust within the Cricket Mountains block that places Lower Cambrian siliciclastic strata on Upper Cambrian carbonates, and that we have interpreted as the regional Pavant thrust. As noted above, this thrust, identifiable through industry well ties, shows clearly on seismic data as a set of reflections that can be mapped with high confidence throughout the southwest Cricket Mountains block (fig. 12A). The strong, planar, multi-cycle character of these reflections in the southern basin resembles that of the event beneath the buried Cricket Mountains block in the northern basin that is usually interpreted as the Sevier Desert detachment.

Unfortunately, no seismic data exist that image the full along-strike length of the Cricket Mountains block, and that might thereby tie the surface identified as the Pavant thrust in the south with specific reflections on northern dip profiles such as COCORP Utah Line 1. Some evidence of the tie that we propose, however, does emerge on the northern part of line SEI-2 (fig. 20), which images the Cricket Mountains block south of approximately latitude $39^{\circ} 10^{\prime}$. In the portion of the profile shown, the reflection interpreted as the Pavant thrust deepens to the north, and reaches approximately 2.1 seconds two-way time at the point where the profile crosses the line of profile GSI-1, published by Mitchell and McDonald (1987). At that point, the reflection ties directly to the reflection on line GSI-1 beneath the Cricket Mountains block that Mitchell and McDonald (1987) identify as the Sevier Desert detachment. This correlation thus explains the paradox highlighted above: the apparent continuity of the basin-floor reflection with a strong event beneath the buried Cricket Mountains block north of line GSI-1, and the lack of such continuity south of line GSI-1.

This interpretation, if correct, holds a number of interesting implications for the Sevier Desert story. For one, it requires that the Pavant thrust, which lies well within the Cricket Mountains block and above the hypothesized Sevier Desert detachment in the area south of line GSI-1, deepens and forms the horizon that has hitherto been interpreted as the Sevier Desert detachment at the base of the Cricket Mountains block in the area north of line GSI-1 (see, for example, fig. 20). This geometry is consistent with the detachment hypothesis for basin origin only if the thrust surface bifurcates into two splays south of Line GSI-1. Under such a model, the upper splay would represent the Pavant thrust horizon sampled by the CA industry well, and the lower splay would mark the Tertiary basin-forming Sevier Desert detachment, which merges with the (extensionally reactivated) northern segment of the Pavant thrust at approximately the location of line GSI-1. The record of line SEI-2, however, provides evidence of no such bifurcation. Indeed, reflections beneath the interpreted Pavant thrust are generally concordant with the thrust surface above and show no signs of offset (fig. 20).

CONCLUSION

\section{Future Research Directions for Detachment Studies}

In framing the discussion above, we have adopted a conservative approach. We have devoted most of the text to the implications of the data presented here for the age, slip, and kinematics of the Sevier Desert detachment, which remains the generally accepted model for formation of the Sevier Desert basin. And we have stressed the historical success of the detachment hypothesis in explaining (1) the basin's overall shape, scale, and east-west asymmetry, (2) sedimentary accommodation sufficient to hold more than $4 \mathrm{~km}$ of material in the basin's deepest zones, and (3) the arresting pattern on seismic reflection profiles within the basin of listric or planar normal faults 


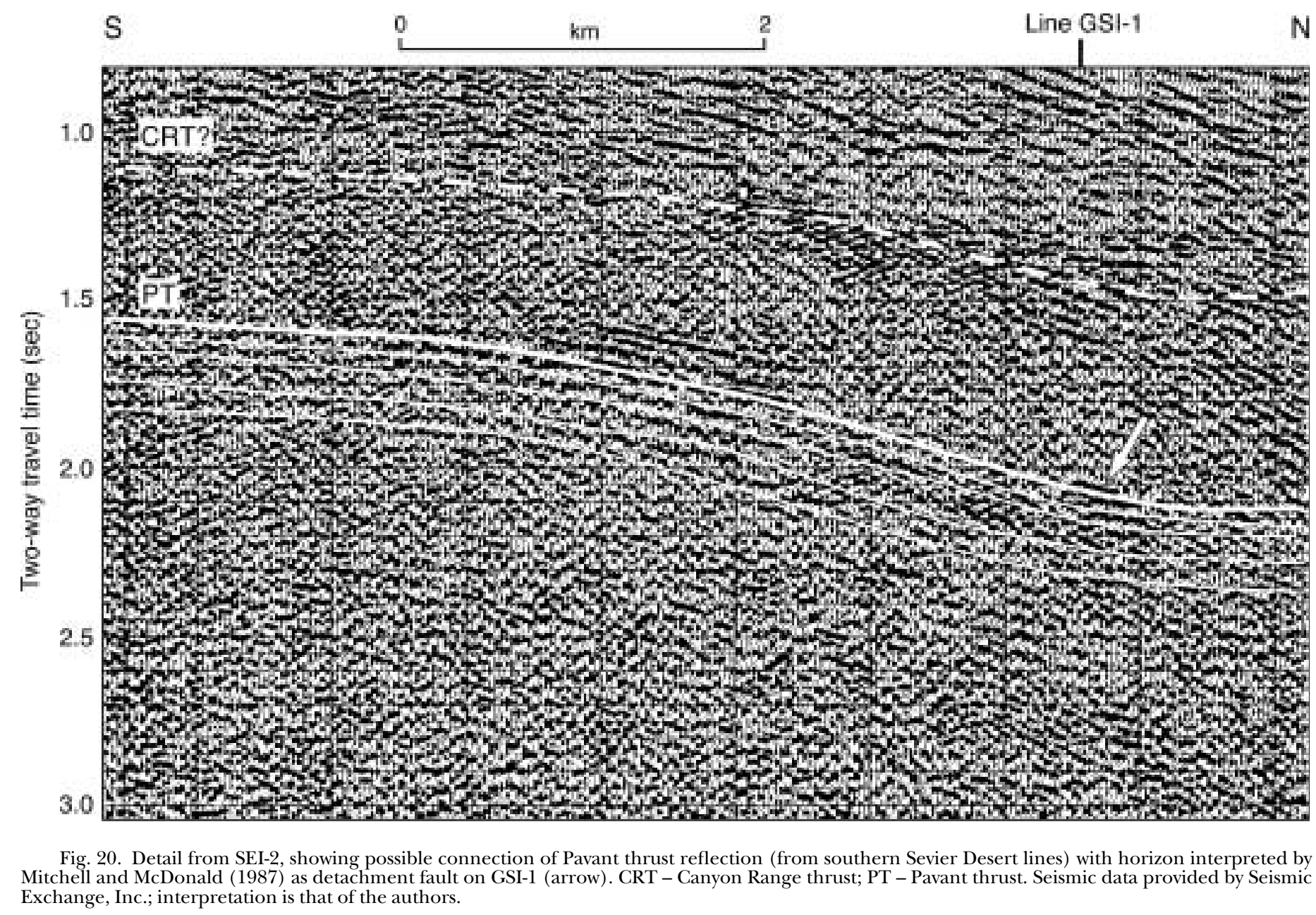

इ5

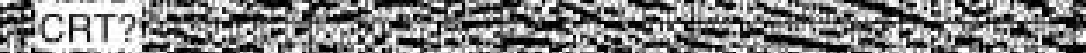

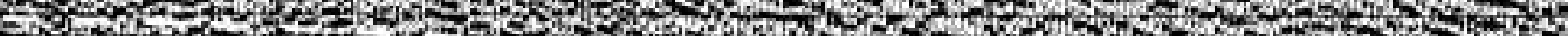

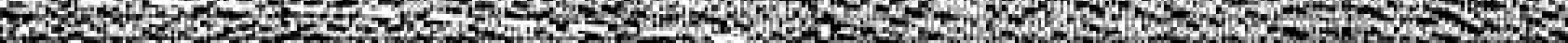

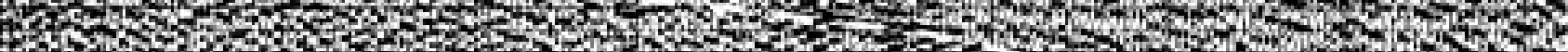

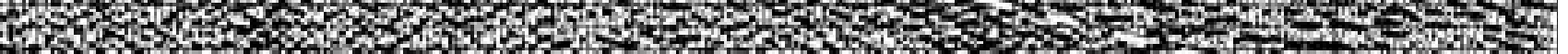

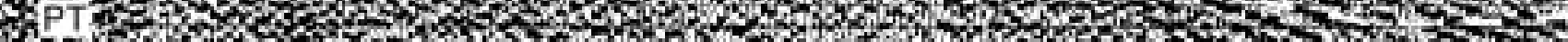

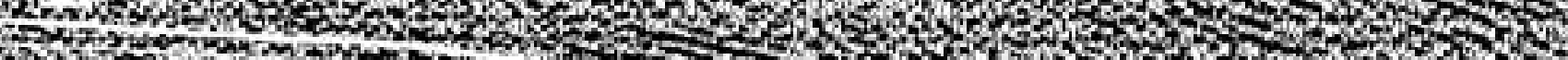
Ho 0 .

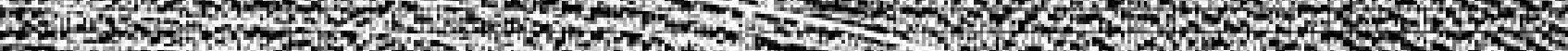

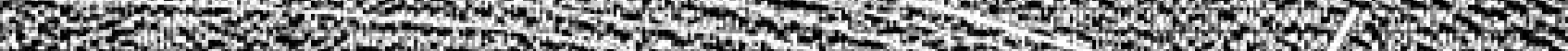

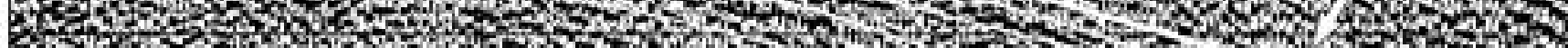

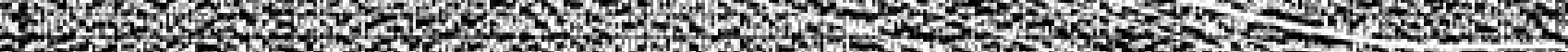

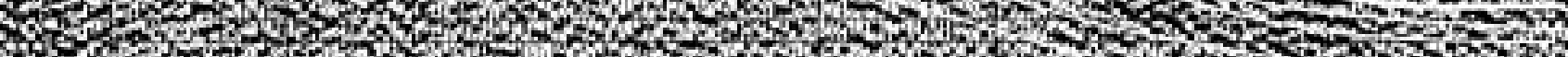

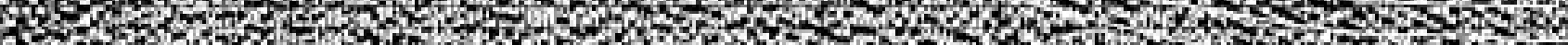

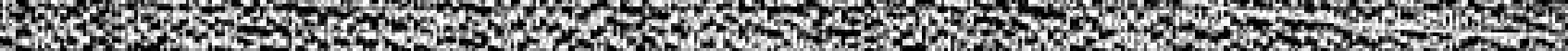

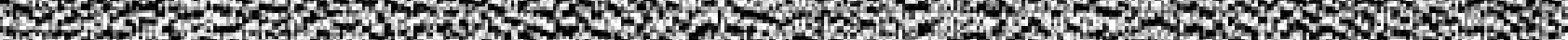

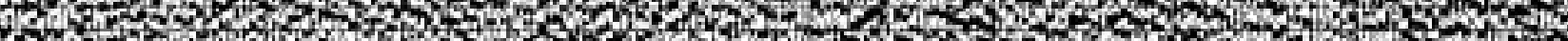

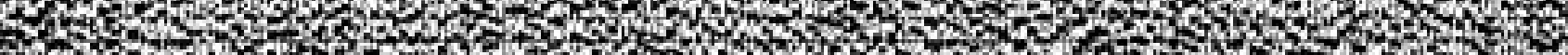

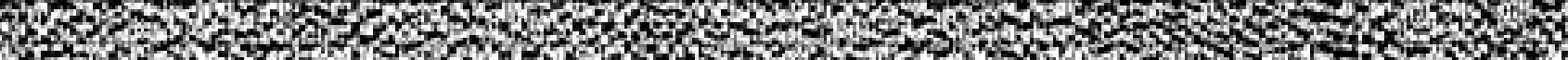

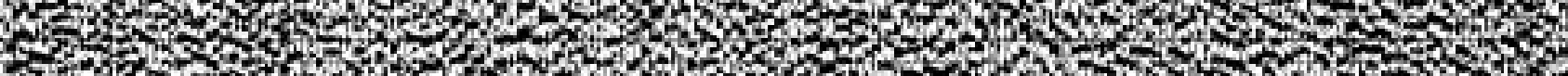

Fig. 20. Detail from SEI-2, showing possible connection of Pavant thrust reflection (from southern Sevier Desert lines) with horizon interpreted by Exchange, Inc.; interpretation is that of the authors. 
that seem to terminate at the Paleozoic-Tertiary contact, with little or no offset of the contact itself.

Yet we have also suggested some potential shortcomings in the detachment model that emerge when the data set for the entire Sevier Desert basin is considered. These include issues that have been raised and discussed in the literature, such as the apparent lack of upper plate brittle deformation or lower plate ductile deformation at the hypothesized detachment (Anders and Christie-Blick, 1994; Anders and others, 2001). They also include issues implicit in previous studies that have not been sufficiently appreciated in the literature, such as the significant difference in the record of seismic profiles in the northern Sevier Desert basin (which show an apparently continuous or quasi-continuous detachment reflection biting deep into the upper crust) from those in the southern basin (where the reflection associated with the detachment fault terminates abruptly at the Cricket Mountains block). And they include issues raised in this study, such as the possible, and paradoxical, continuity of the reflection associated with the hypothesized detachment in lines north of GSI-1 with a prominent reflection within the detachment's own hanging-wall block south of line GSI-1.

We think that an important future research goal for proponents of a detachment explanation will be to incorporate more clearly into their models, which have relied heavily on data from the northern Sevier Desert basin, the subsurface record from the southern basin as well-in many ways a richer record than that of the northern basin, but one for which a through-going, crustal-scale detachment is a less obvious solution than in the north. Is it possible, for example, that notwithstanding their present-day status as part of the same physiographic province, the southern Sevier Desert subbasin experienced a structural and depositional history different from that of the northern subbasin? Could the intrabasin high separating the two subbasins have a larger tectonic significance, separating two different regimes built by two different structural mechanisms (Hugh Hurlow, personal communication, 2003)? While the limited seismic data available to address this issue (for example, line SEI-2) seem to suggest a continuous link between the northern and southern basins, answering these questions will require considerably more, better-quality data in the currently data-poor area separating the northern and southern subbasins.

\section{Toward an Alternative Model of the Sevier Desert Basin}

Another possible research direction lies in investigating alternative hypotheses for the basin that do not rely on detachment faulting. In that spirit, we use the final paragraphs of this study to outline one such (highly speculative) model, presented by substantially greater detail by Wills (ms, 2000) and diagrammed in figure 21.

The alternative model begins with the notion that the Sevier Desert depression originated as a small "satellite basin" (Ricci Lucchi, 1986) west of the main foreland in the closing stages of the Sevier orogeny, and that the Tertiary Sevier Desert basin inherited its general shape and asymmetry from the pre-existing Mesozoic orogenic fabric. After emplacement of the regional Canyon Range and Pavant thrust sheets, uplift on underlying thrusts beneath the Sevier Desert basin, some of them likely basement-involved, led to substantial erosion of the older allochthons, with patterns of erosion largely controlled by Mesozoic structures. A late-stage, basement-involved, backward-breaking thrust west of the Sevier Desert, underlying the present-day House Range, may have loaded the basin and imparted an initial westward tilt on the basin floor giving rise to erosional patterns recorded in the undulatory shape of the Paleozoic-Tertiary contact within the basin. After thrusting ceased, Tertiary sediments began ponding in the residual erosional topography.

Miocene-and-younger high-angle normal faulting on both the eastern and western margins of the basin, augmented by isostatic adjustment due to sediment loading, could have accounted for no more than $1 \mathrm{~km}$ of total sedimentary accommodation. 

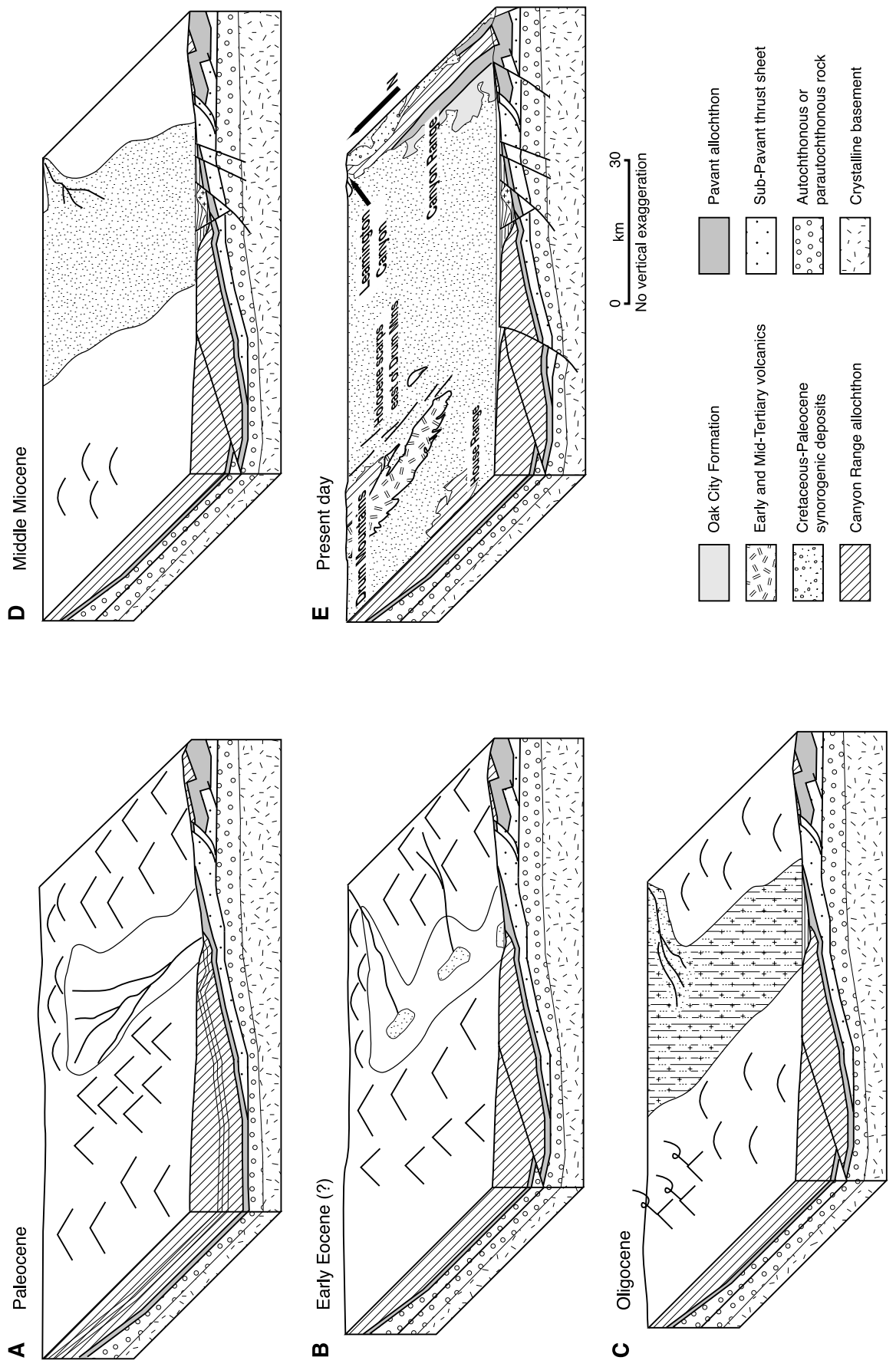
Thus, in a non-detachment context, the bulk of accommodation would instead have to have come from regional subsidence through much of the Cenozoic, again augmented by sediment loading, with relatively little total upper-crustal extension in the basin relative to the highly extended terranes exposed further west. The hypothesized regional subsidence - driven by intracratonic "sag basin"-type mechanisms, by regional lower-crustal thinning tied to localized upper-crustal extension in the central Great Basin, west of the Sevier Desert (see, for example, Gans, 1987), or by sublithospheric loading related to sinking of the Farallon slab (as modeled in other contexts by Gurnis [1992, 1993] and Mitrovica and others [1989]) — would also explain the $\sim 1$ km Eocene-to-Holocene elevation decline in the House Range estimated paleobotanically by Gregory-Wodzicki (1997) and Chase and others (1998).

If a detachment fault is not responsible for the Sevier Desert basin's creation, and if the bulk of sedimentary accommodation came from regional subsidence, what is the origin of the detachment geometries so spectacularly imaged on industry and academic seismic profiles from within the Sevier Desert basin (McDonald, 1976; Allmendinger and others, 1983; Mitchell and McDonald, 1987; Planke, ms, 1987)? One possibility, we suggest, is that those geometries arose not from the rooted process of regional detachment faulting, but from the nonrooted process of intrabasin salt tectonics. We illustrate this possibility with two cross-sections, one from the northern Sevier Desert basin (fig. 22), constrained by seismic line PC-8 (fig. 6), published by McDonald (1976) and Mitchell and McDonald (1987) and by the AE well, and the other from the southern basin (fig. 23), based on line V-5 and the records of the AMF and AHR wells. Out-of-section movement of salt is permitted in these reconstructions, in keeping with generally accepted practices of tectonic reconstruction in saltdominated areas (see, for example, Hossack, 1995; Buchanan and others, 1996).

The two cross-sections reflect different styles of salt mobility that may have been at work in different parts of the basin at a variety of scales. These differing styles, interestingly, may hold a key to understanding one difference between the subsurface records of the northern and southern Sevier Desert basin. As noted above, in the north, seismic-reflection profiles feature abundant growth strata, in many cases abutting large antiformal or domelike structures that are demonstrably salt cored. In the southern basin, tilted strata more commonly show little or no stratal growth, and much of the tilted sediment terminates westward against a basin-bounding listric fault. We propose that these differing stratal patterns may reflect the differing styles of salt mobility hinted at in figures 22 and 23. In the northern basin, where initial salt

Fig. 21. Block diagram showing tentative alternative tectonic model for the Sevier Desert basin. Front of the model approximately coincides the latitude of COCORP Line 1, and stretches from the Canyon Range, at the eastern edges of the Sevier Desert basin (fig. 1), to the House Range, slightly west of the area covered by figure 1. (A) Paleocene. Uplift of Canyon Range and Pavant allochthons, and of anticlinal folds within those thrust sheets, on deeper thrust, along with imbricate thrusting immediately west of the Canyon Range syncline, creates a small "satellite" depression west of the main foreland area. An axial drainage system controlled by the uplift of the anticlinal folds to the west, and possibly augmented by a "funnel effect" due to residual highlands to the north - transports eroded material to depocenters south of the present-day Sevier Desert area. (B) Early Eocene(?). Late-stage, basement-involved thrusting west of the present-day Sevier Desert basin, at the close of the Sevier orogeny, loads the basin area and creates relative highlands west of the basin. The loading imparts a slight westward tilt to the basin floor, which in turn allows development of a transverse drainage system into the present-day basin depocenters, particularly from the area that will become the present-day Leamington Canyon. Sediments begin to pond into residual orogenic topography. (C) Oligocene. Broad regional subsidence leads to formation of a large, saline lake. Salt is contributed largely from Jurassic salt-bearing deposits exposed east of the present-day Sevier Desert basin, and transported into the basin through the proto-Leamington Canyon. (D) Mid-Miocene. High-angle faulting in the basin area creates additional sedimentary accommodation, and also triggers salt withdrawal and re-emplacement in selected areas. (E) Present-day geology. Uplift of fault-block mountains, such as the Canyon Range, Drum Mountains, and House Range, forms additional space for sedimentation, and exposes the geology seen in present-day map-view relations. 


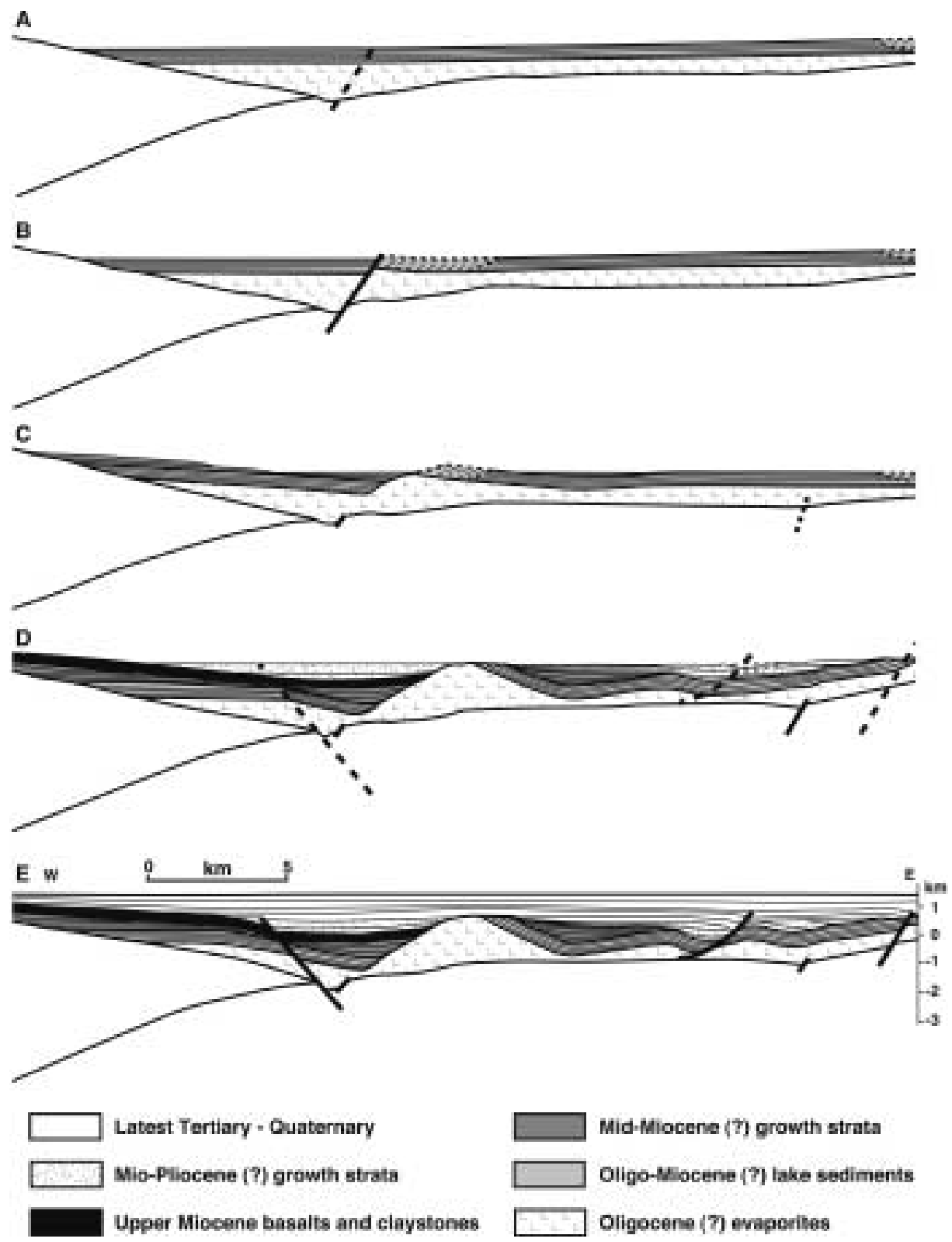

Fig. 22. Section restored for salt mobility, northern Sevier Desert basin. Line of section corresponds to trace of seismic profile PC-8 (fig. 1). Diagrams show inferred basin geometry for (A) the Oligocene to early Miocene, (B) the early to mid Miocene, (C) the mid to late Miocene, (D) the Pliocene, and (E) the present day. High-angle basement faulting in the early to mid Miocene is inferred to have mobilized evaporites of Oligocene age, which domed up flat-lying lake sediments and led to adjacent wedges of growth strata.

thicknesses may have been greater, salt withdrawal formed large graben adjacent to spatially extensive, domal salt-cored structures of considerable thickness. In the south, where initial salt may have been thinner and interbedded with other sediments, salt withdrawal took place at a smaller scale, and re-emplacement may have been in the form of small, swaly, pillow-like structures. 


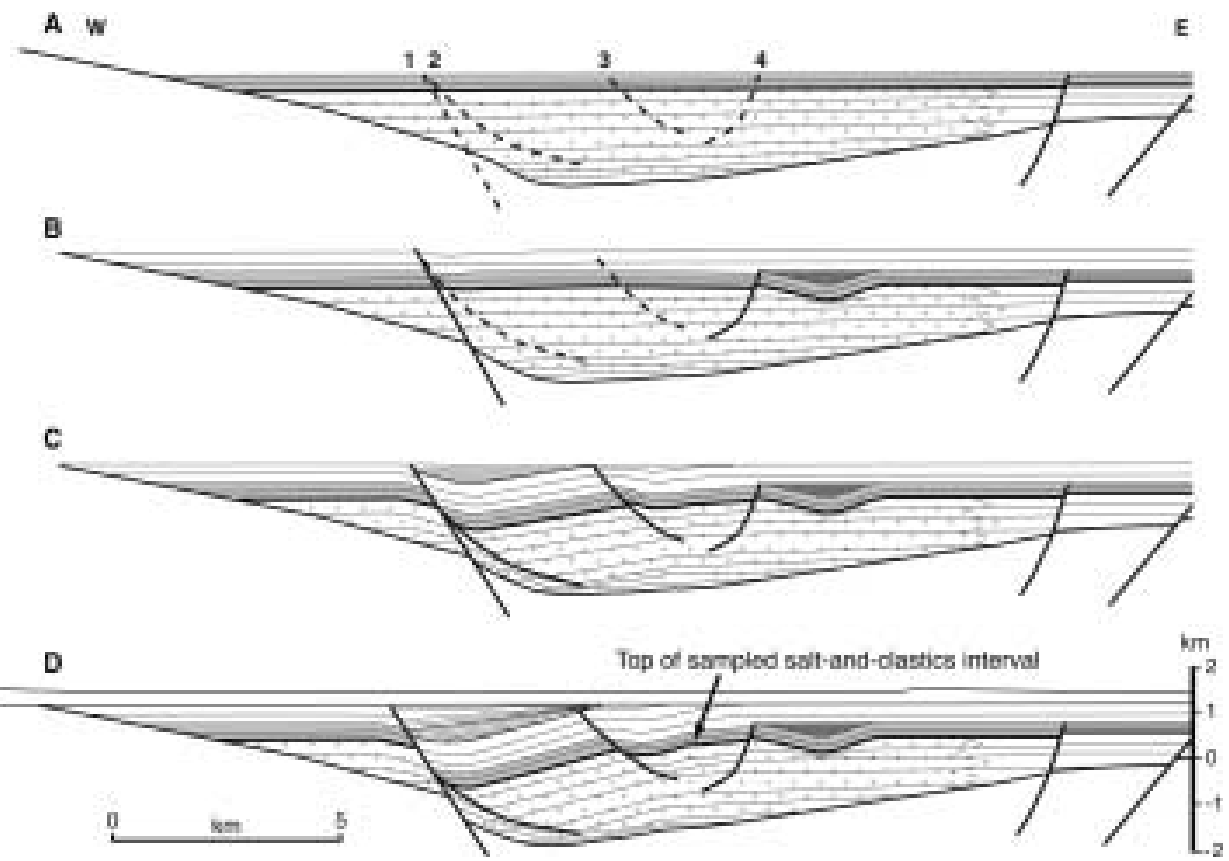

Fig. 23. Illustrative cross-section, showing possible role of salt mobility in shaping some of the sedimentary geometry in the central and southern Sevier Desert basin. Line of section corresponds to seismic profile V-5 (fig. 1). Timing of events is broadly taken as late Oliogocene to Recent, but cannot be constrained further using available data. (A) Initial condition. Regional subsidence has led to formation of a broad, saline lake, which has resulted in deposition of fine clastic sediments interspersed with evaporites (plus signs). Shaded interval at top of section is non-evaporitic. Numbered faults are those active during the span under consideration; dashed lines mark locations of incipient faults, and solid lines represent faults that have accommodated some motion. (B) A small salt-withdrawal basin has developed in the eastern half of the section, leading to minor offset on listric fault 4 , and has subsequently been covered by flat-lying sediments. Withdrawn salt is interpreted to have been re-emplaced outside of the line of section. (C) Initial offset on high-angle rooted fault 1 triggers withdrawal of evaporitic material and also some gravity-driven sliding on non-rooted listric fault 2, which soles into the weak evaporitic layer. The gravity-sliding component of the motion gives rise to compressive stresses in the sediments further to the east, which are accommodated by slight reverse offset on listric fault 3 . A wedge of growth sediments is deposited in the small basin formed over the tilted block between faults 2 and 3. (D) Present-day subsurface geometry. Continued offset on rooted high-angle fault 1 has further tilted the block bounded by listric faults 2 and 3, and has allowed deposition of additional growth strata. Fault 3 has been reactivated in a normal sense. Subsequent to motion on the rooted fault, the area is overlain unconformably by late Quaternary deposits. Arrow shows top of interval of interlayered salt and clastic sediments sampled by Arco Hole-In-Rock well, and tied to line V-5 via line SEI-4.

While this tentative model may explain a number of observations better than the detachment-faulting alternative (such as the lack of evidence of brittle or ductile deformation at the hypothesized detachment fault contact, and the signficant differences between the northern and southern seismic record), in its current form the model raises a number of significant issues. Although the presence of some salt and salt-related structures in the basin is well established, Coogan and DeCelles (1996) argued that the volume of evaporites in the basin is insufficient to explain the volume of growth strata; settling this question will require considerably more data on the three-dimensional distribution of evaporites in the basin than are currently available. In a larger sense, none of the specific regional-subsidence mechanisms suggested above seems adequate, in itself, to explain the amount of required sedimentary accommodation, even including the effects of sediment loading. Instead, multiple 
subsidence mechanisms interacting over the basin's long history would have been required (Wills, ms, 2000) - a scenario the veracity of which may be difficult to establish. And the amount of uplift envisioned for the Canyon Range, on the east side of the basin (fig. 21F), falls far short of the 4.5 to $5.6 \mathrm{~km}$ or more inferred by Stockli and others (2001) in their interpretation of apatite fission-track data from the range.

We recognize these (and possibly other) shortcomings, and stress that this speculative model represents a "first cut" rather than the last word. Indeed, we hope that this alternative model - and, in a larger sense, the data and subsurface relations presented in this study-will suggest alternative perspectives, and will spur renewed dialogue and work on the subsurface geology of what remains a fascinating area.

\section{ACKNOWLEDGMENTS}

This study would not have been possible without the assistance of a variety of persons in obtaining seismic data and in providing permission to publish that data. Thanks to Scot Krueger, Tom LaHouse, and Don Munhausen for facilitating use of the Vastar lines. Gary Mitchell acted as an intermediary in obtaining permission to use the SEI profiles, and Julie Kay Hardie and Christine Glimour, of Seismic Exchange, Inc., supplied permission to publish the lines; both efforts are much appreciated. Thanks also to Doug Sprinkel for leads to a variety of data sources and for lending a copy of the mudlog from the Placid Oil Henley well. We gratefully acknowledge the efforts of the Records Department staff at the Utah Division of Oil, Gas, and Mining, for their assistance in obtaining geophysical logs and well records; of Carolyn Olsen, curator of the Utah Geological Survey Sample Library, for her kind help as we examined industry well material; and of Leanna Hand at Reilly, Inc., for providing geophysical logs and mudlogs for several crucial wells. We thank Lehi Hintze and Gary Mitchell for insightful discussions. Andrew Meigs, Hugh Hurlow, Suzanne Janecke, and Julio Friedman provided detailed, fair, and useful reviews of the manuscript. The work reported herein was partly funded by a National Science Foundation (NSF) Graduate Research Fellowship and an American Association of Petroleum Geologists Grant-inAid, by NSF grant EAR - 99-02782 and Petroleum Research Fund of the American Chemical Society grants 32194 - AC2 and 39706- AC8.

Appendix A

SELECTED SEVIER DESERT SEISMIC PROFILES

In this Appendix, we present full-length reproductions of the previously unpublished seismic profiles from Vastar Resources and Seismic Exchange, Inc., that are discussed in the main text. For the profiles from Vastar, both uninterpreted and interpreted versions are offered. For the SEI profiles, unfortunately, our publication agreement stipulates that the profiles be presented only in interpreted form; however, we have endeavored to make our interpretations as unobtrusive as possible, to allow readers to evaluate alternative interpretations. 


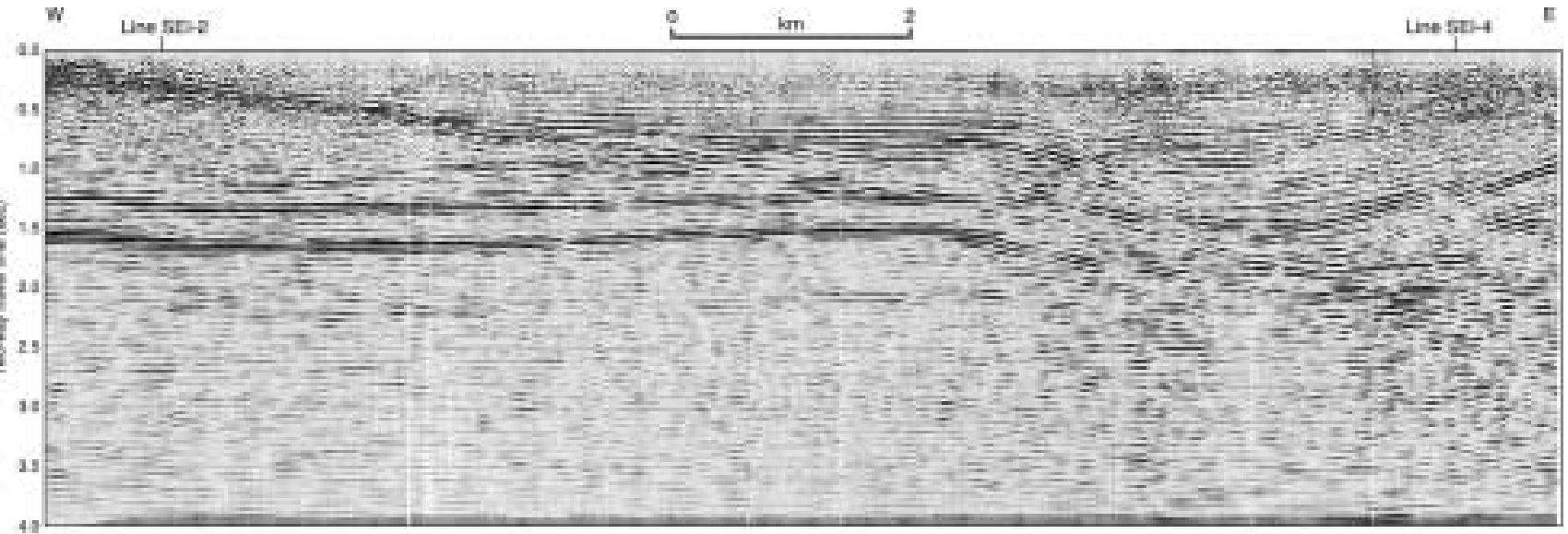

Fig. A1. Western half of line V-5. Seismic data provided by Vastar Resources, Inc.; interpretation is that of the authors. 

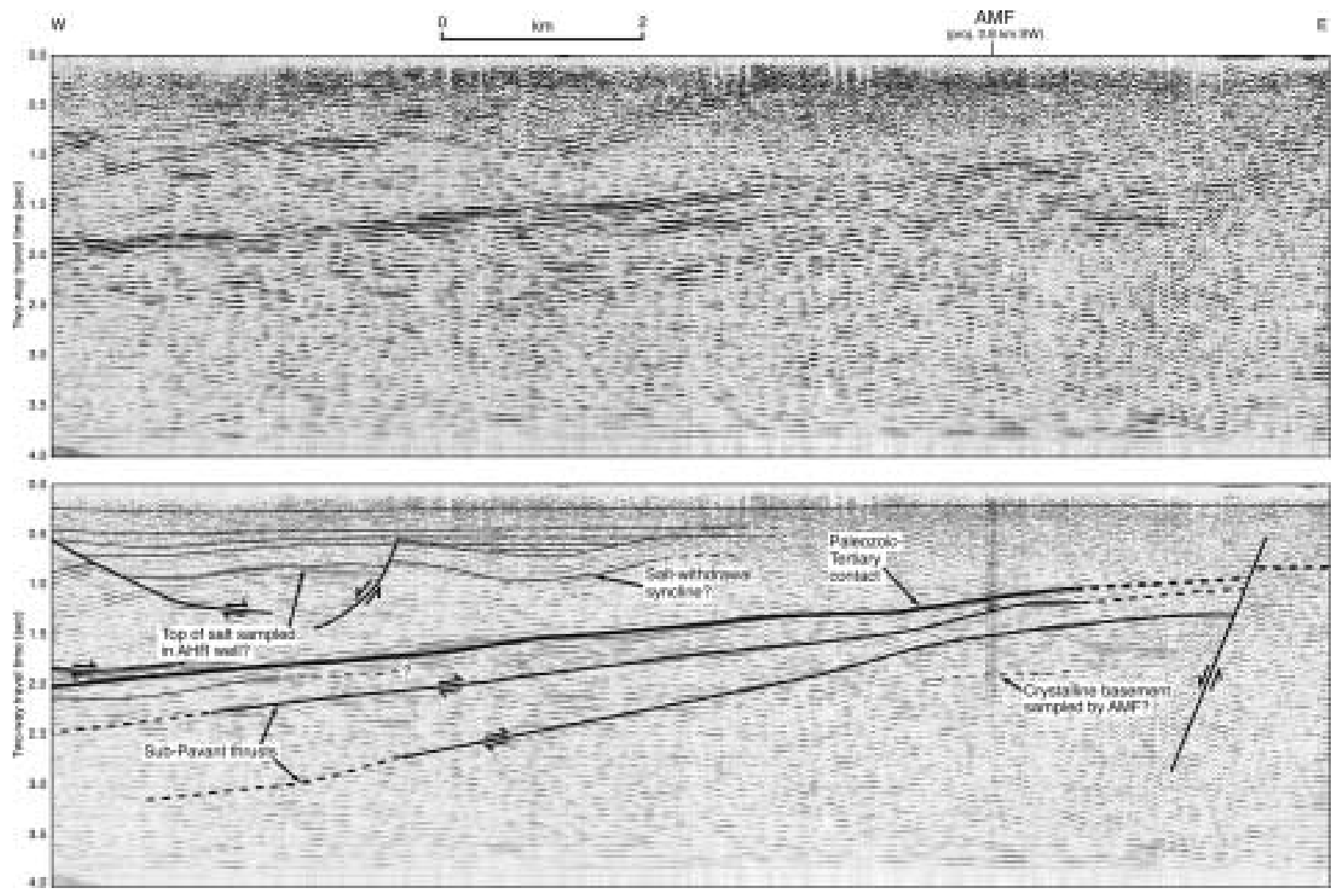

Fig. A2. Eastern half of line V-5. Seismic data provided by Vastar Resources, Inc.; interpretation is that of the authors. 


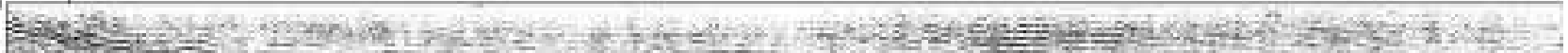

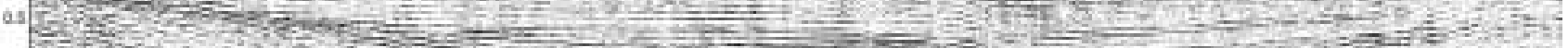

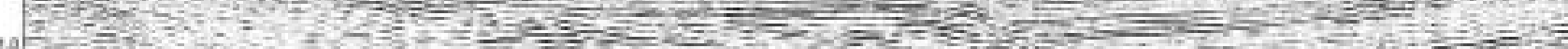

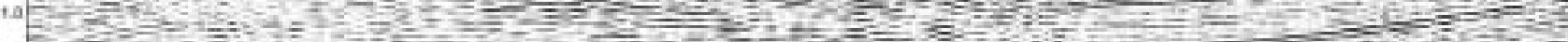

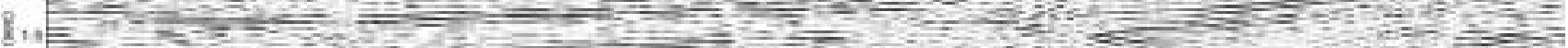

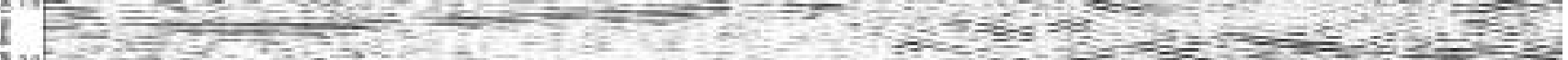

20 - 7 -

2.
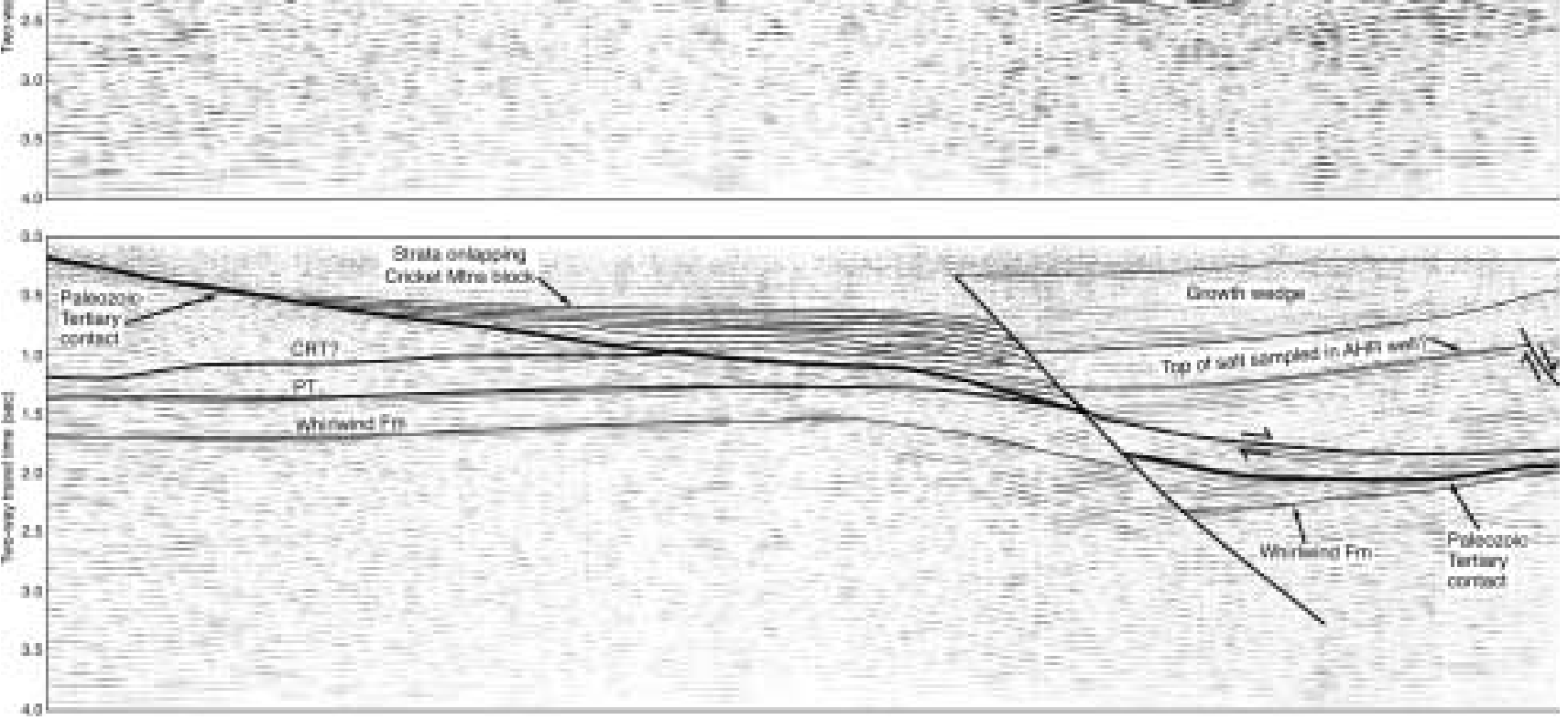

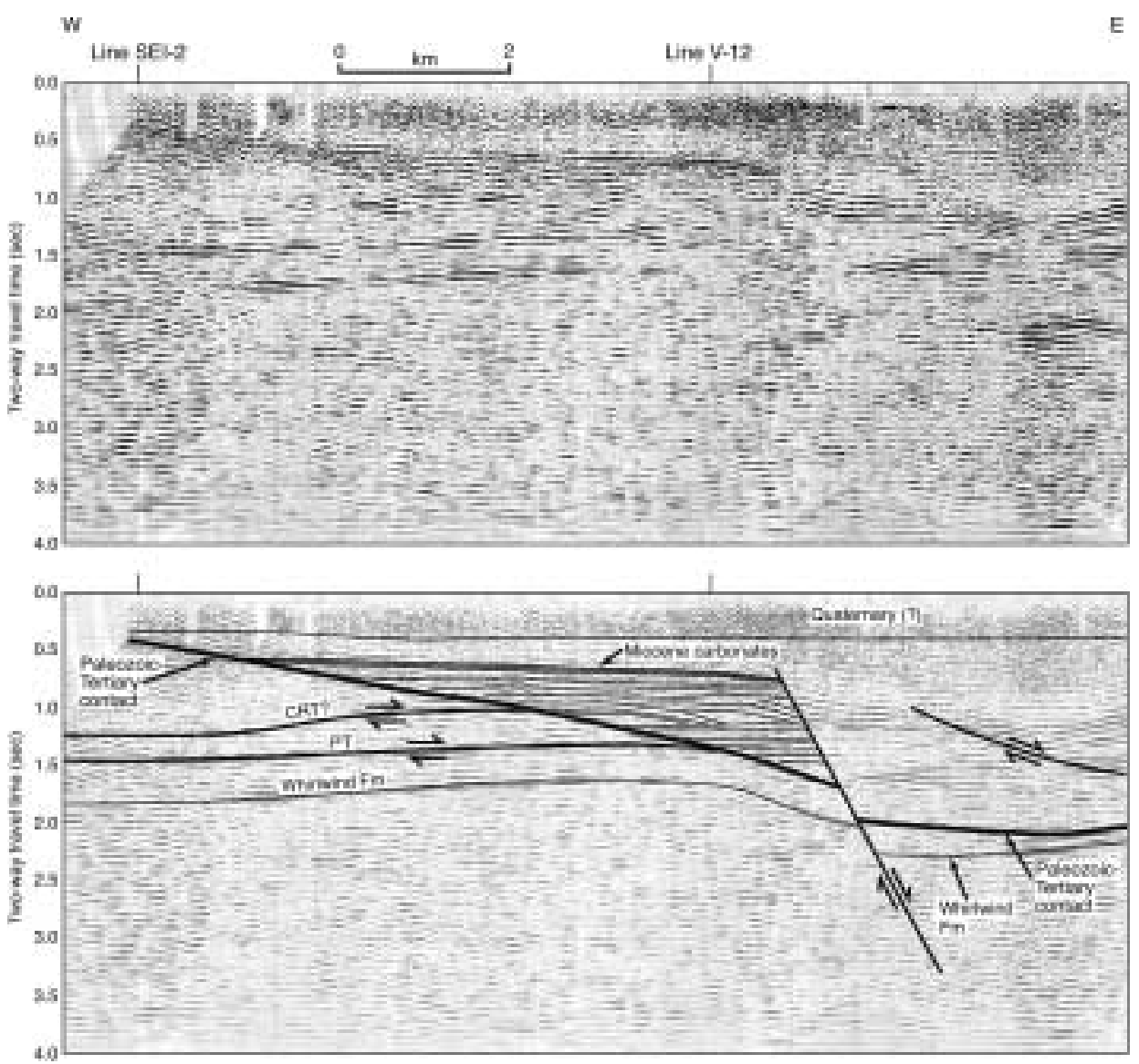

Fig. A4. Line V-11. Seismic data provided by Vastar Resources, Inc.; interpretation is that of the authors. 


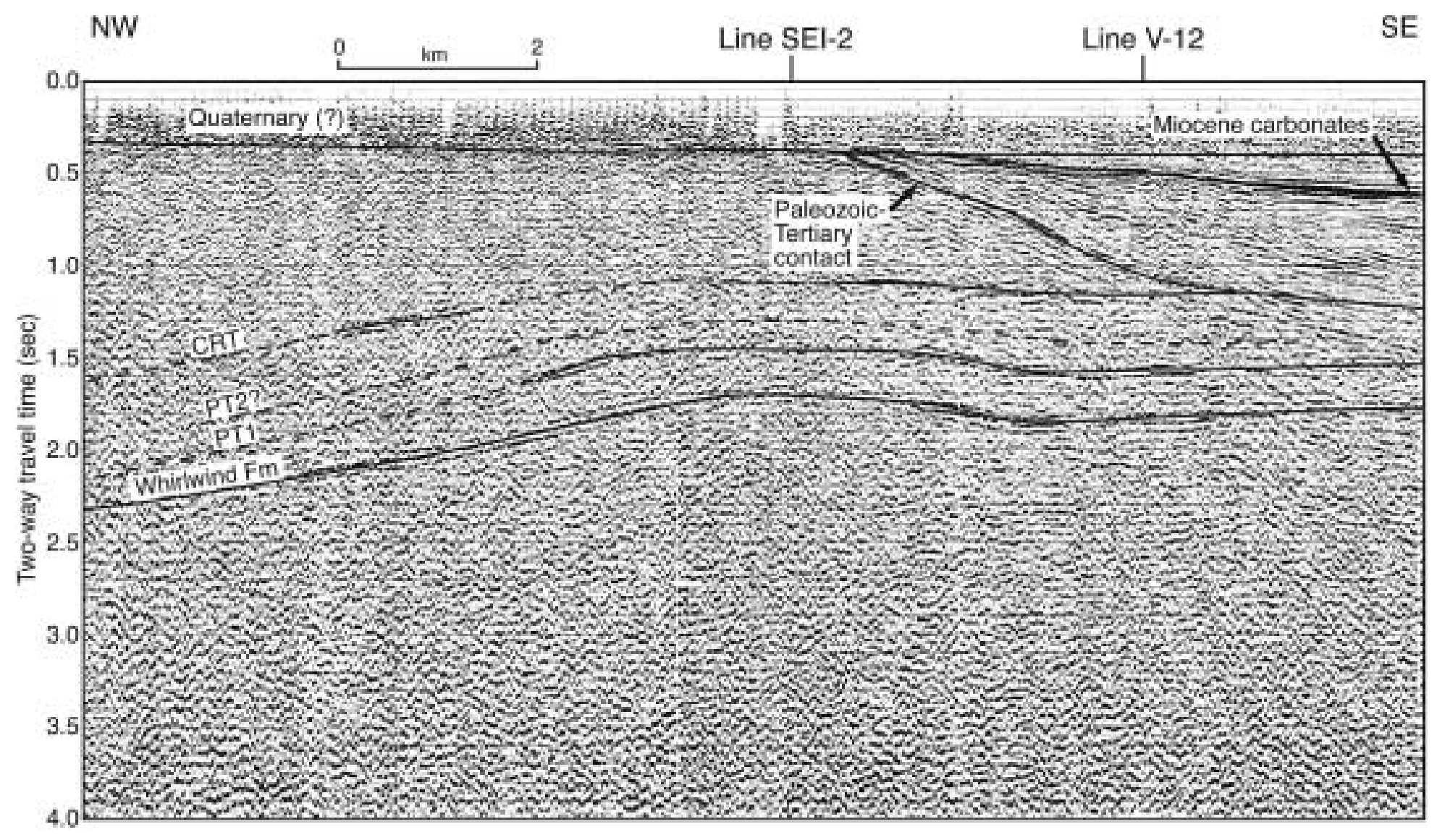




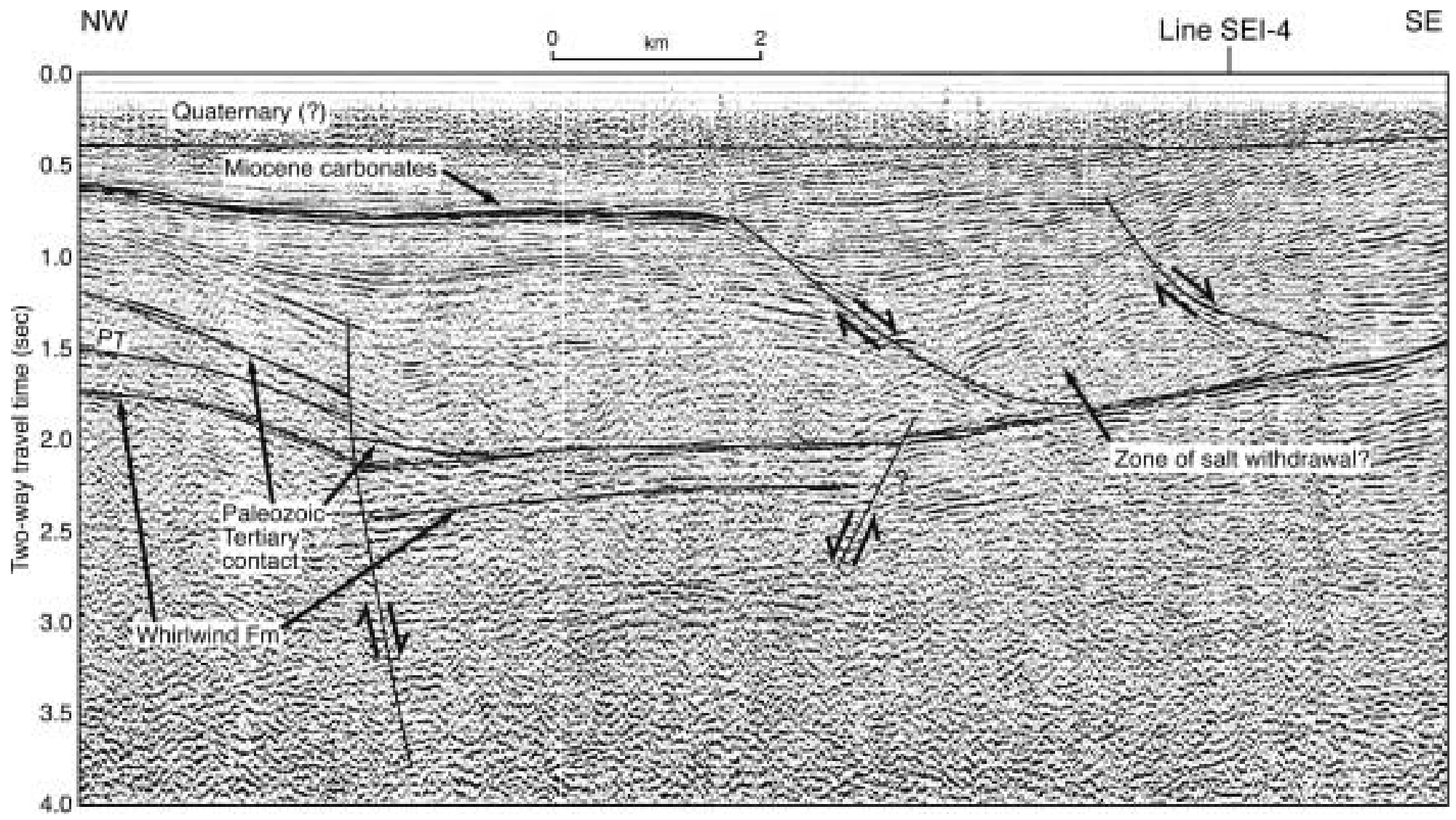

Fig. A6. Line SEI-1 (continued). Seismic data provided by Seismic Exchange, Inc.; interpretation is that of the authors. 


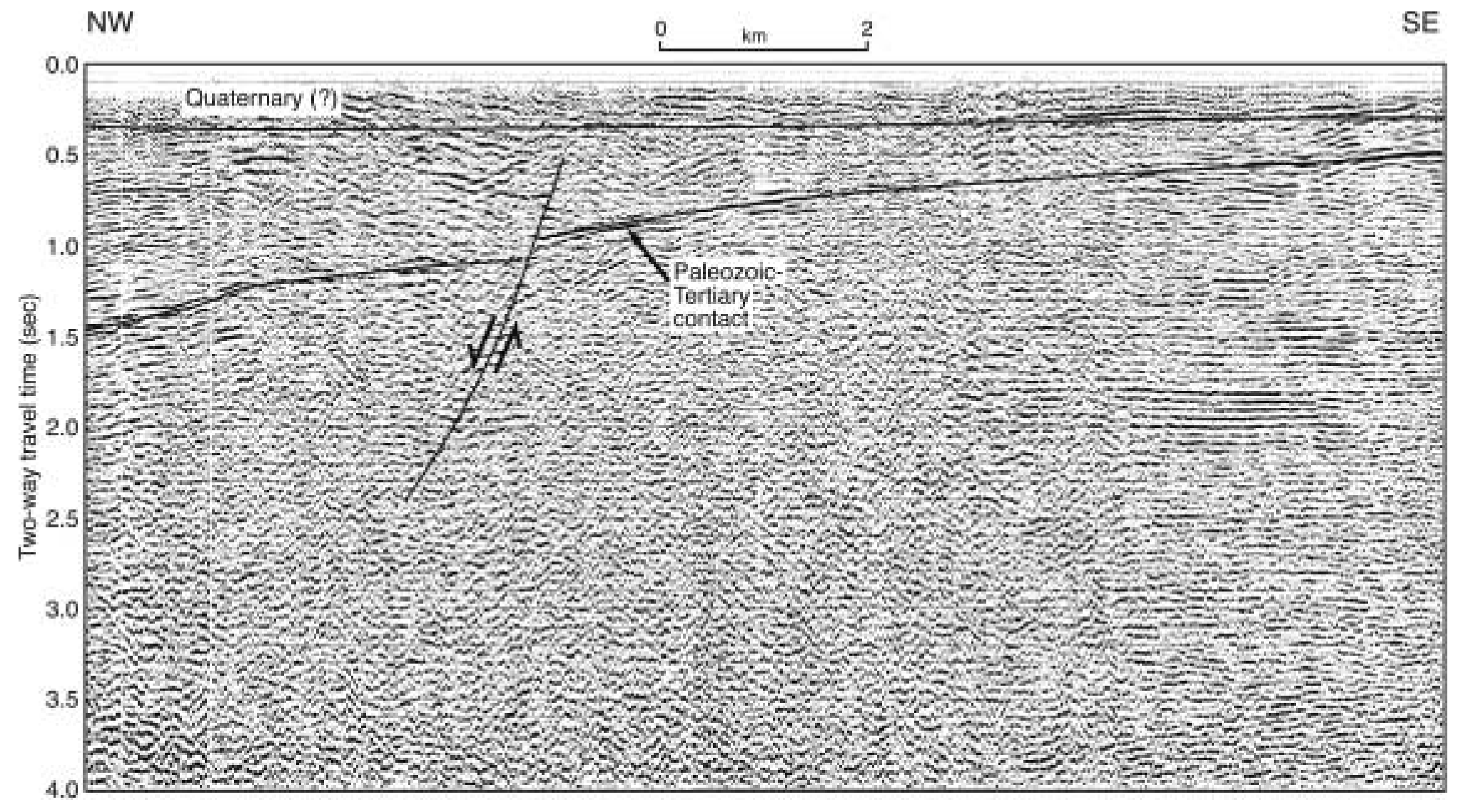

SE

Fig. A7. Line SEI-1 (continued). Seismic data provided by Seismic Exchange, Inc.; interpretation is that of the authors. 


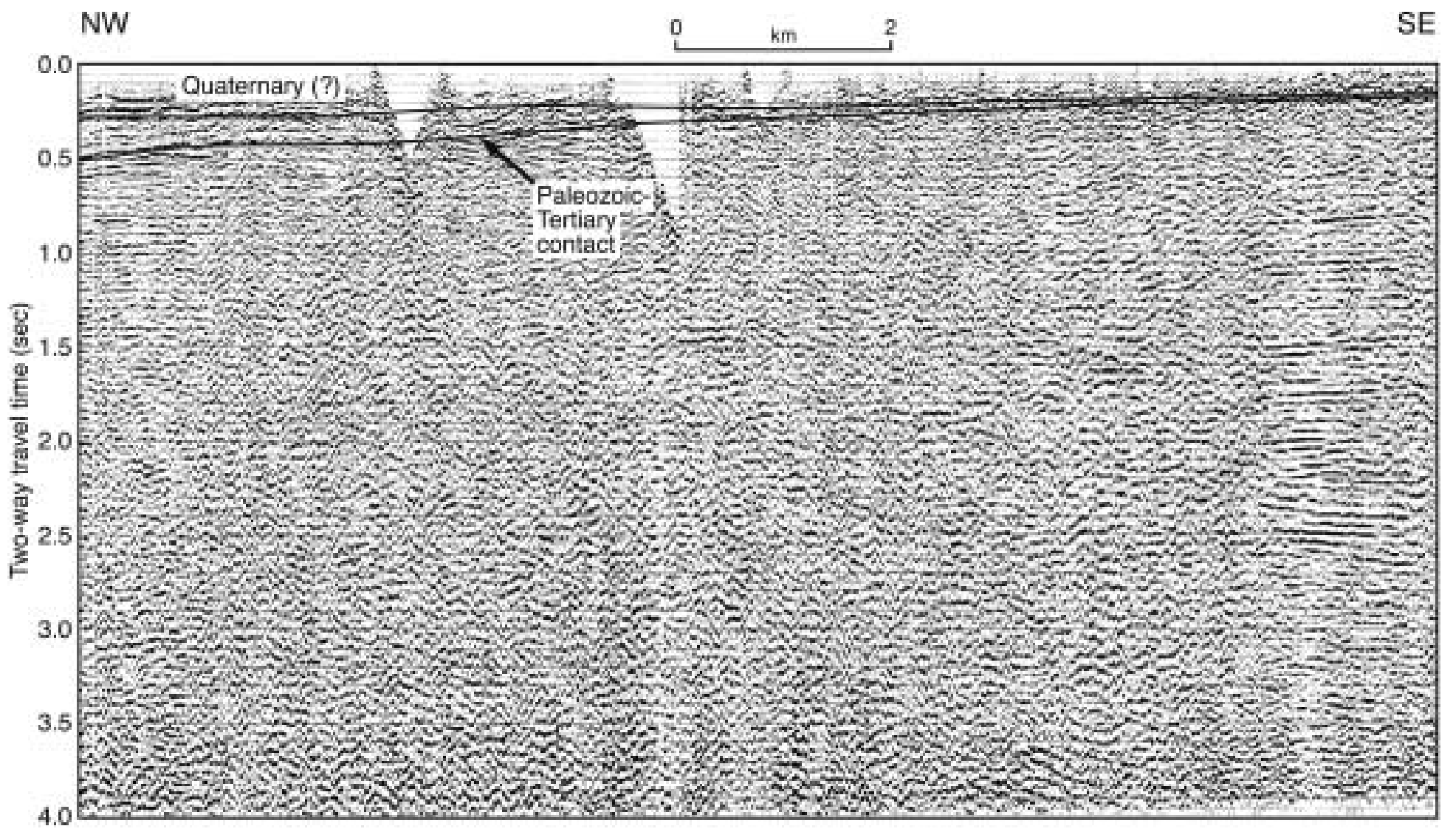

Fig. A8. Line SEI-1 (end). Seismic data provided by Seismic Exchange, Inc.; interpretation is that of the authors. 


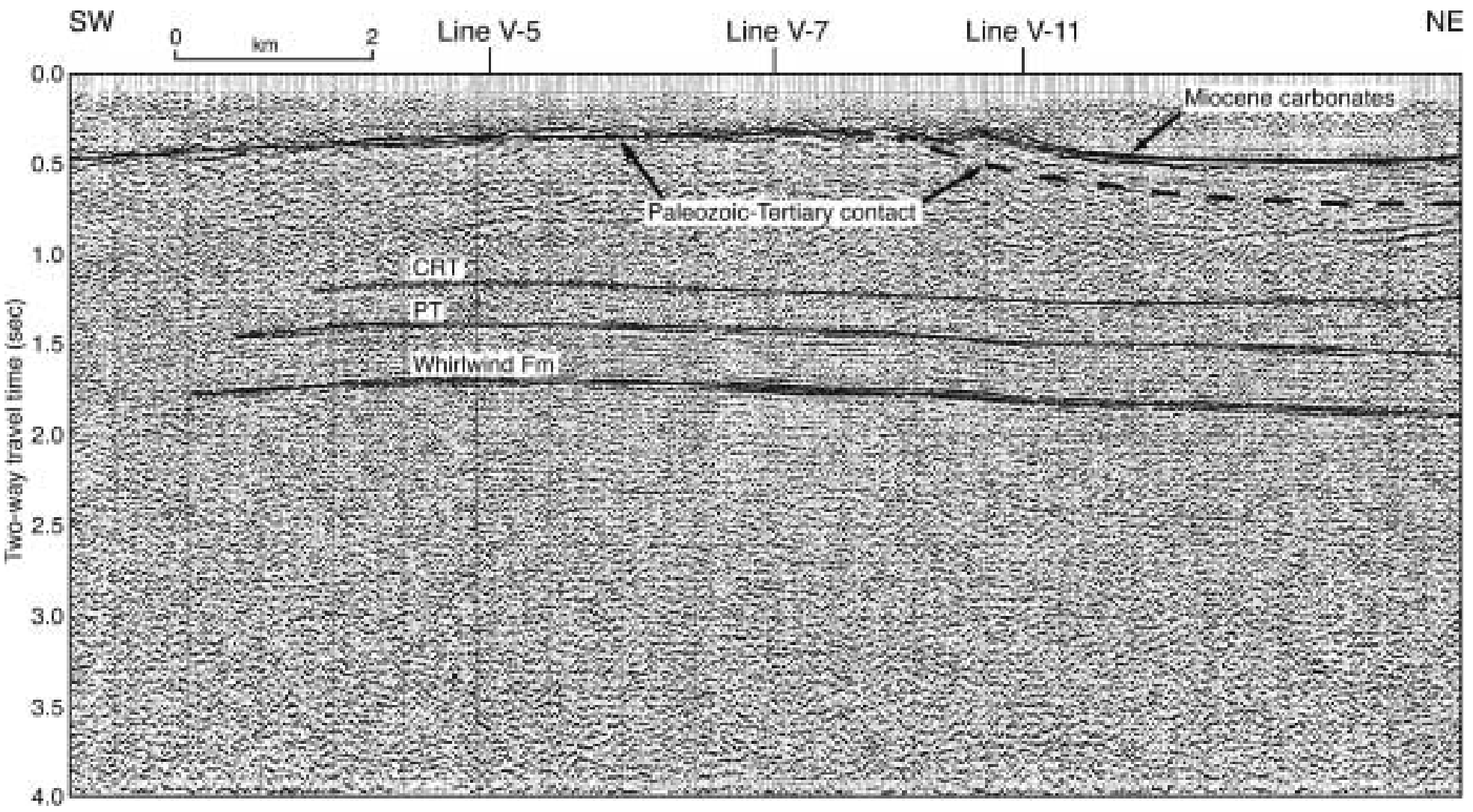

Fig. A9. Line SEI-2 (beginning). Seismic data provided by Seismic Exchange, Inc.; interpretation is that of the authors. 


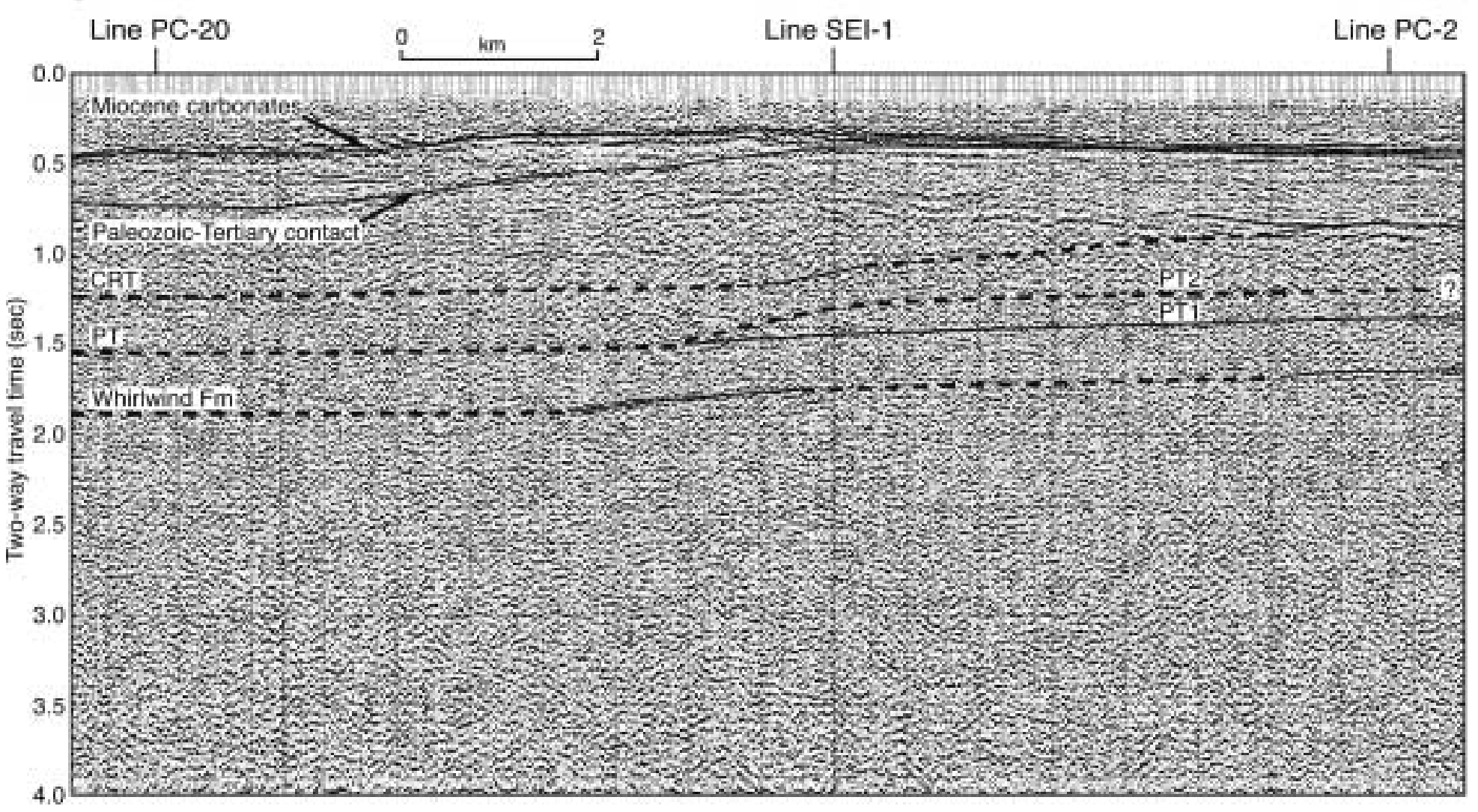

Fig. A10. Line SEI-2 (continued). Seismic data provided by Seismic Exchange, Inc.; interpretation is that of the authors. 
SW

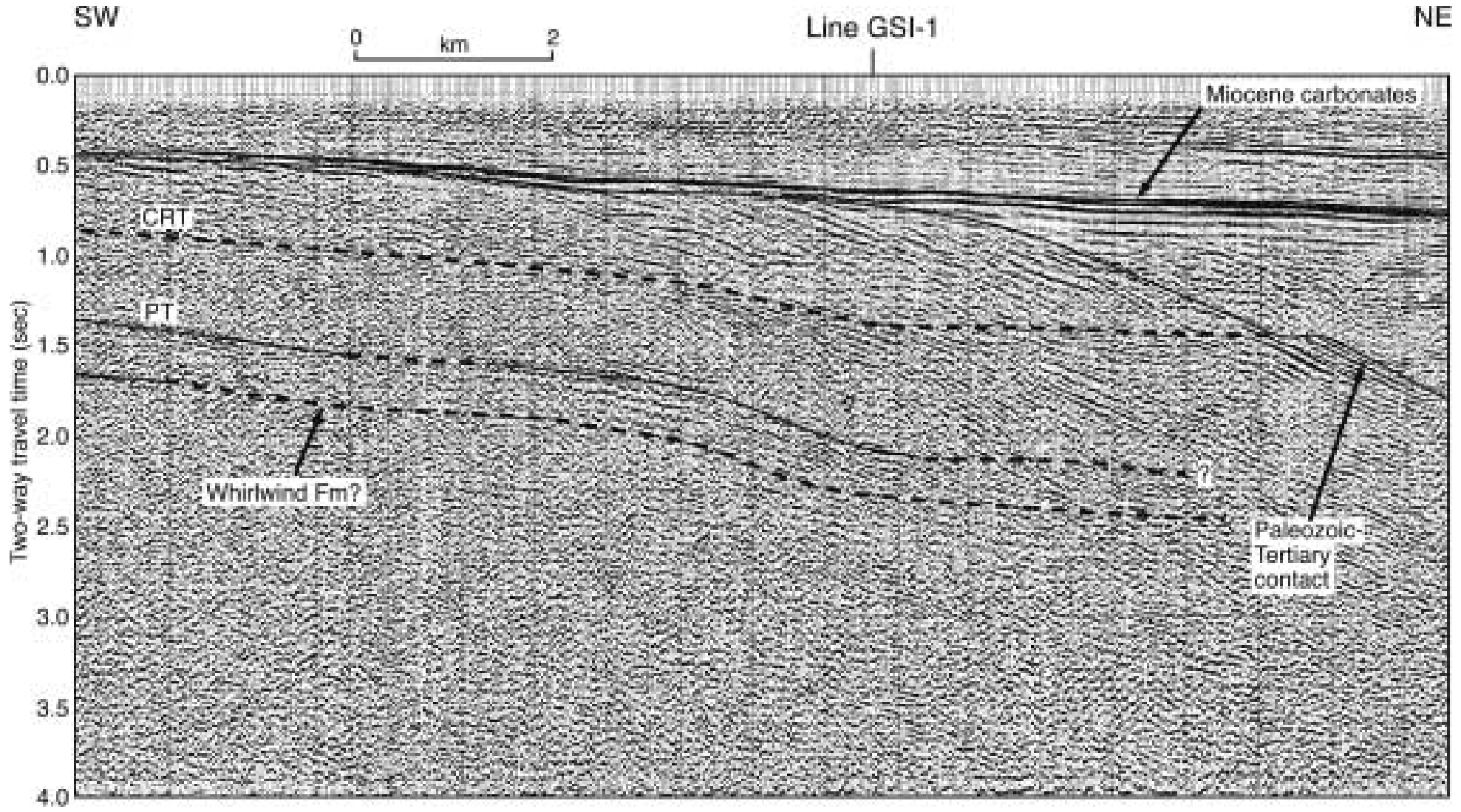


$\mathrm{N} \cong$

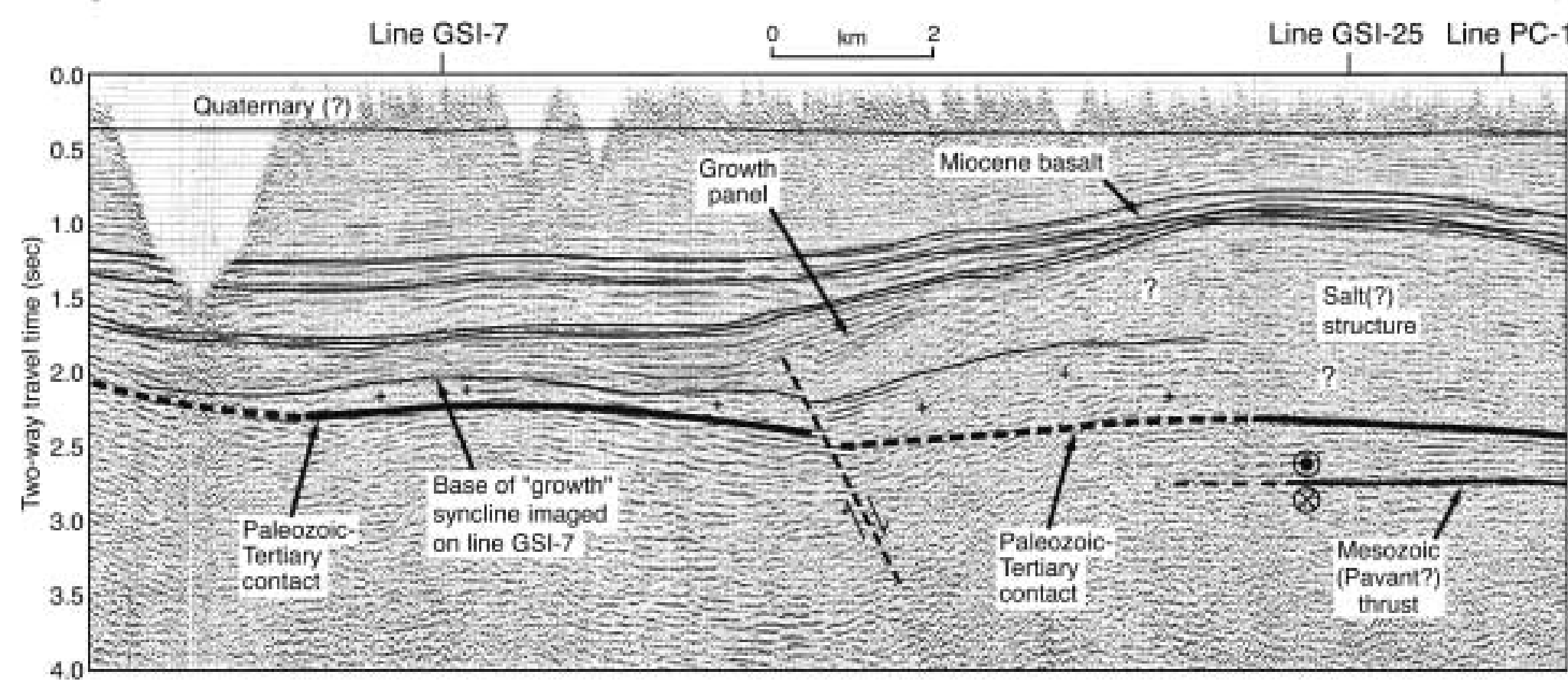

Fig. A12. Line SEI-2N (beginning). Seismic data provided by Seismic Exchange, Inc.; interpretation is that of the authors. 


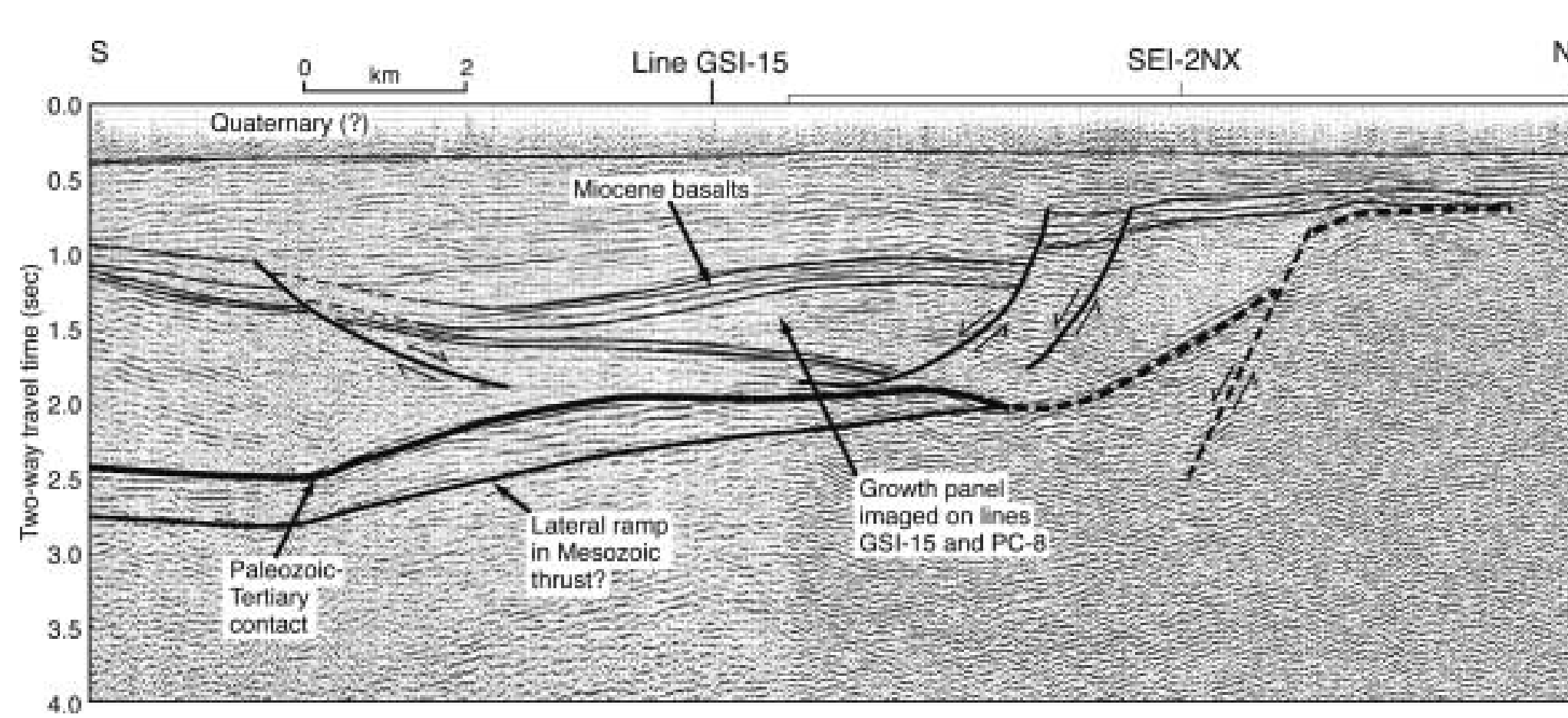

Fig. A13. Line SEI-2N and 2NX (end). Seismic data provided by Seismic Exchange, Inc.; interpretation is that of the authors. 


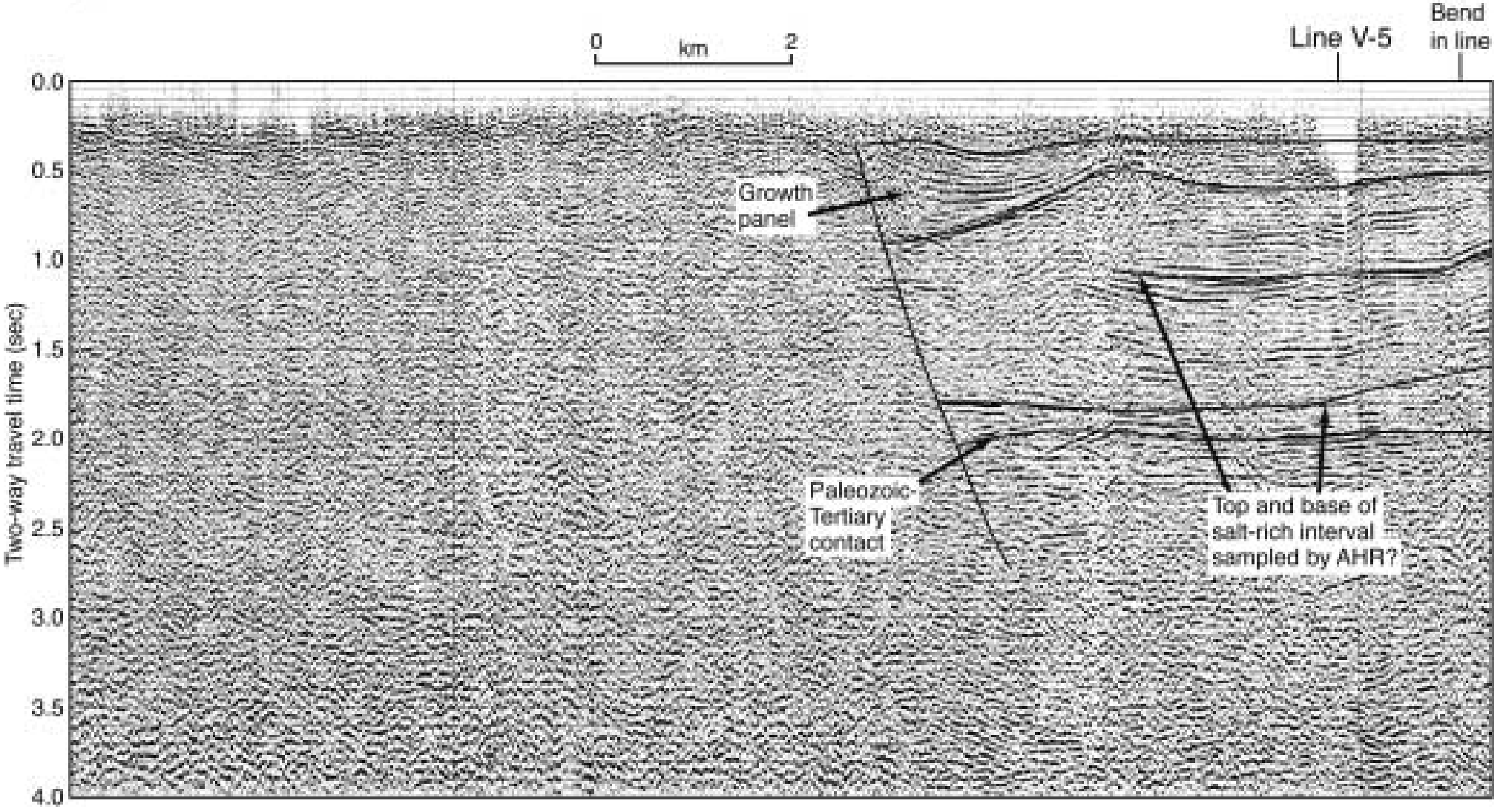

Fig. A14. Line SEI-4 (beginning). Seismic data provided by Seismic Exchange, Inc.; interpretation is that of the authors. 


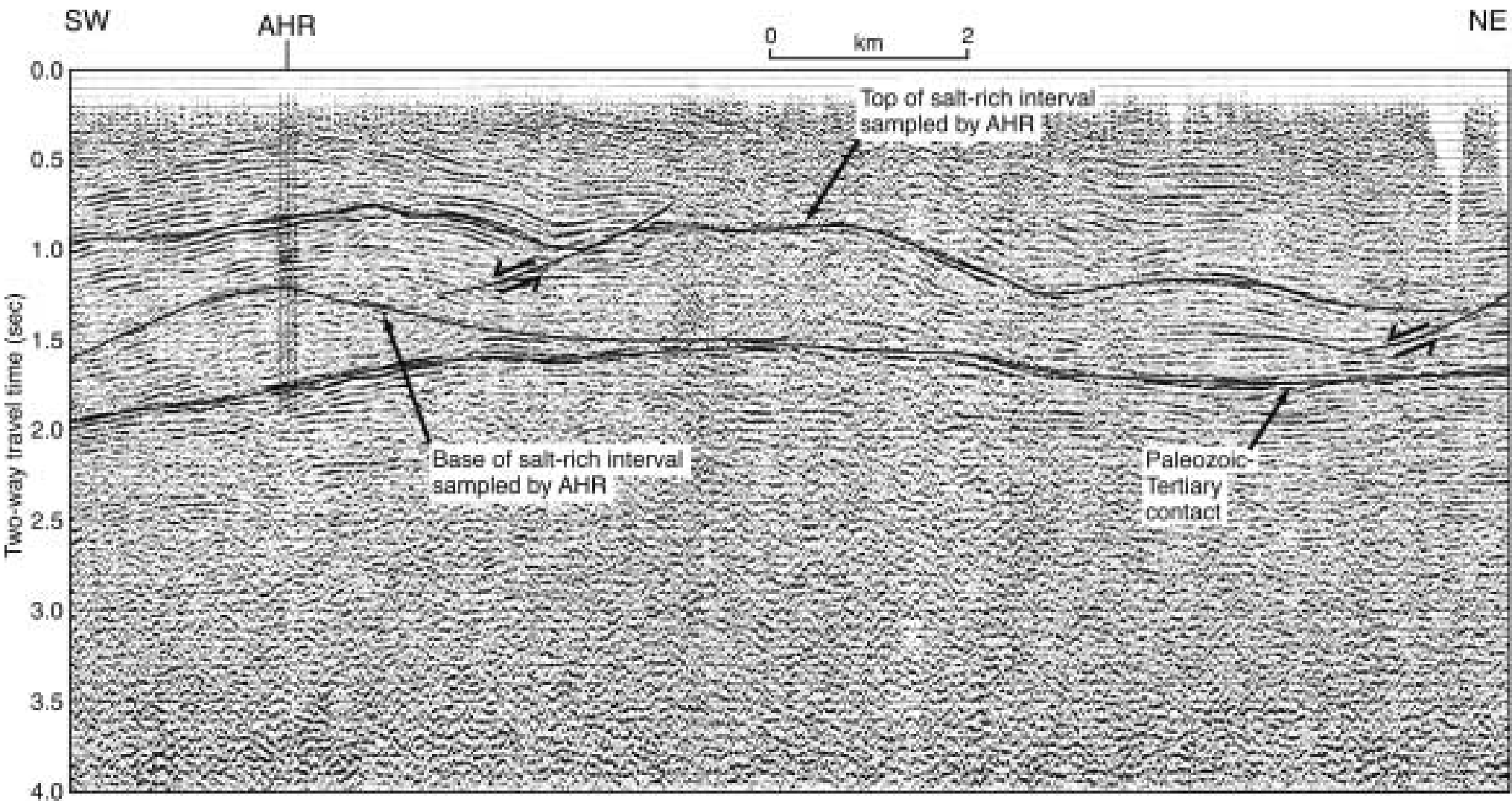




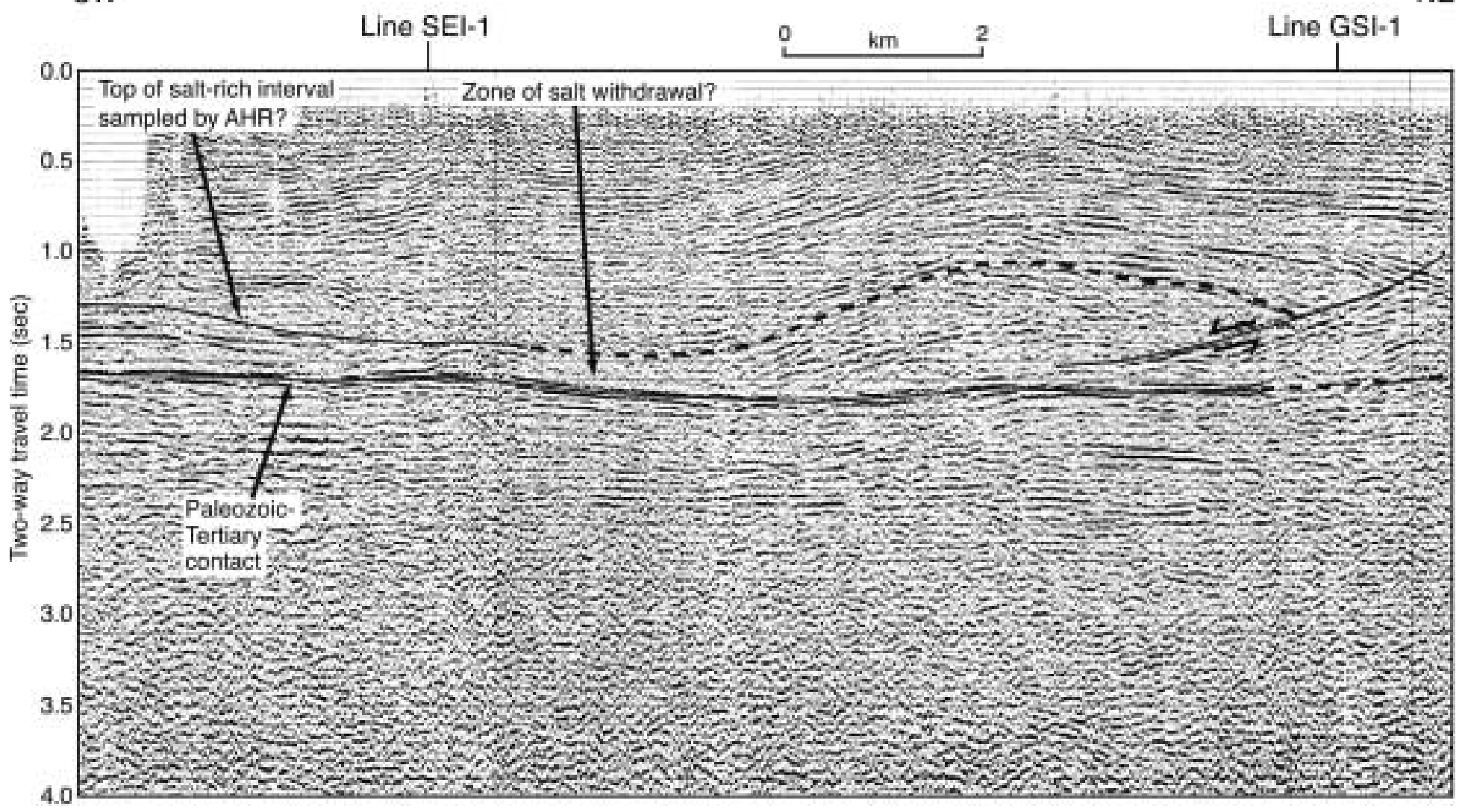

Fig. A16. Line SEI-4 (end). Seismic data provided by Seismic Exchange, Inc.; interpretation is that of the authors. 


\section{REFERENCES}

Allmendinger, R. W., 1992, Fold and thrust tectonics of the western United States exclusive of the accreted terranes, in Burchfiel, B. C., Lipman, P. W., and Zoback, M. L., editors, The Cordilleran Orogen: Conterminous U.S.: Boulder, Colorado, Geological Society of America, p. 583-607.

Allmendinger, R. W., and Royse, F., Jr., 1995, Is the Sevier Desert reflection of west-central Utah a normal fault?: Comment, Geology, v. 23, p. 669-670.

Allmendinger, R. W., Sharp, J. W., Von Tish, D., Serpa, L., Brown, L., Kaufman, S., Oliver, J., and Smith, R. B., 1983, Cenozoic and Mesozoic structure of the eastern Basin and Range province, Utah, from COCORP seismic reflection data: Geology, v. 11, p. 532-536.

Allmendinger, R. W., Sharp, J., Von Tish, D., Oliver, J., and Kaufman, S., 1985, A COCORP crustal-scale seismic profile of the Cordilleran hingeline, eastern Basin and Range province, in Gries, R. R., and Dyer, R. C., editors, Seismic exploration of the Rocky Mountain region: Denver, Rocky Mountain Association of Geologists and Denver Geophysical Society, p. 23-30.

Allmendinger, R. W., Hauge, T. A., Hauser, E. C., Potter, C. J., Klemperer, S. L., Nelson, K. D., Knuepper, P., and Oliver, J., 1987, Overview of the COCORP $40^{\circ} \mathrm{N}$ Transect, western United States: The fabric of an orogenic belt: Geological Society of America Bulletin, v. 98, p. 308-319.

Anders, M. H., 1993, The Sevier Desert detachment of west-central Utah: Is it a normal fault?: Geological Society of America Abstracts with Programs, v. 25, no. 6, p. A475.

Anders, M. H., and Christie-Blick, N., 1994, Is the Sevier Desert reflection of west-central Utah a normal fault?: Geology, v., 22, p. 771-774.

Anders, M. H., and Wiltschko, D. V., 1994, Microfracturing, paleostress and the growth of faults: Journal of Structural Geology, v. 16, p. 795-815.

Anders, M. H., Christie-Blick, N., and Wills, S., 1995, Is the Sevier Desert reflection of west-central Utah a normal fault?: Reply: Geology, v. 23, p. 670.

1998, Extensional collapse along the Sevier Desert reflection, northern Sevier Desert basin, western United States: Comment: Geology, v. 26, p. 474.

Anders, M. H., Christie-Blick, N., Wills, S., and Krueger, S. W., 2001, Rock deformation studies in the Mineral Mountains and Sevier Desert of west-central Utah: Implications for upper crustal low-angle normal faulting: Geological Society of America Bulletin, v. 113, p. 895-907.

Anderson, E. M., 1942, The dynamics of faulting and dyke formation with application to Britain: White Plains, New York, Oliver and Boyd, $191 \mathrm{p}$.

Anderson, R. E., Zoback, M. L., and Thompson, G. A., 1983, Implications of selected subsurface data on the structural form and evolution of some basins in the northern Basin and Range province, Nevada and Utah: Geological Society of America Bulletin, v. 94, p. 1055-1072.

Armstrong, R. L., 1968, Sevier orogenic belt in Nevada and Utah: Geological Society of America Bulletin, v. 79 , p. $429-458$.

Axen, G. J., 1992, Pore pressure, stress increase, and fault weakening in low-angle normal faulting: Journal of Geophysical Research, v. 97, p. 8979-8991.

Axen, G. J., and Selverstone, J., 1994, Stress state and fluid-pressure level along the Whipple detachment fault, California: Geology, v. 22, p. 835-838.

Bankey, V., and Cook, K. L., 1989, Complete Bouguer gravity map and related geophysical maps of the Delta $1^{\circ} \times 2^{\circ}$ quadrangle, Utah: United States Geological Survey Miscellaneous Field Studies Map MF-2081-A, scale 1:250,000.

Brock, W. G., and Engelder, T., 1977, Deformation associated with the movement of the Muddy Mountains overthrust in the Buffington window, southeastern Nevada: Geological Society of America Bulletin, v. 88 , p. $1667-1677$.

Buchanan, P. G., Bishop, D. J., and Hood, D. N., 1996, Development of salt-related structures in the Central North Sea: Results from section balancing, in Alsop, G. I., Blundell, D. J., and Davison, I., editors, Salt tectonics: Geological Society Special Publication 100, p. 111-128.

Buck, W. R., 1988, Flexural rotation of normal faults: Tectonics, v. 7, p. 959-973.

Campbell, J. A., 1979, Middle to Late Cenozoic stratigraphy and structural development of the Canyon Range, central Utah: Utah Geology, v. 6, p. 1-16.

Chase, C. G., Gregory-Wodzicki, K. M., Parrish, J. T., and DeCelles, P., 1998, Topographic history of the western Cordillera of North America and controls on climate, in Crowley, T. J., and Burke, K., editors, Tectonic boundary conditions for climate model simulations: Oxford Monographs on Geology and Geophysics 39, p. 73-99.

Christie-Blick, N., 1982, Upper Proterozoic and Lower Cambrian rocks of the Sheeprock Mountains, Utah: Regional correlation and significance: Geological Society of America Bulletin, v. 93, p. 735-750.

Cloos, E., 1968, Experimental analysis of Gulf Coast fracture patterns: American Association of Petroleum Geologists Bulletin, v. 52, p. 420-444.

Collettini, C., and Sibson, R. H., 2001, Normal faults, normal friction?: Geology, v. 29, p. 927-930.

Coogan, J. C., and DeCelles, P. G., 1996, Extensional collapse along the Sevier Desert reflection, northern Sevier Desert basin, western United States: Geology, v. 24, p. 933-936.

Coogan, J. C., DeCelles, P. G., Mitra, G., and Sussman, A. J., 1995, New regional balanced cross section across the Sevier Desert region and the central Utah thrust belt: Geological Society of America Abstracts with Programs, v. 27, no. 4, p. 7.

Cook, K. L., Adhidjaja, J. I., and Gabbert, S. C., 1981, Complete Bouguer gravity anomaly and generalized geology map of Richfield $1^{\circ} \times 2^{\circ}$ quadrangle, Utah: Salt Lake City, Utah Geological and Mineral Survey Map 51, scale 1:250,000.

Cook, K. L., Bankey, V., Mabey, D. R., and DePangher, M., 1989, Complete Bouguer gravity anomaly map of Utah: Salt Lake City, Utah Geological and Mineral Survey Map 122, scale 1:500,000.

Crittenden, M. D., Schaeffer, F. E., Trimble, D. E., and Woodward, L. A., 1971, Nomenclature and 
correlation of some Upper Precambrian and basal Cambrian sequences in western Utah and southeastern Idaho: Geological Society of America Bulletin, v. 82, p. 581-602.

Crittenden, M. D., Coney, P. J., and Davis, G. H., editors, 1980, Cordilleran metamorphic core complexes: Geological Society of America Memoir 153, 490 p.

Crone, A. J., and Harding, S. T., 1984, Relationship of late Quaternary fault scarps to subadjacent faults, eastern Great Basin, Utah: Geology, v. 12, p. 292-295.

Davis, R. L., 1983, Geology of the Dog Valley-Red Ridge area, southern Pavant Mountains, Millard County, Utah: Brigham Young University Geology Studies, v. 30 (part 1), p. 19-36.

DeCelles, P. G., Lawton, T. F., and Mitra, G., 1995, Thrust timing, growth of structural culminations, and synorogenic sedimentation in the type Sevier orogenic belt, western United States: Geology, v. 23, p. 699-702.

Dommer, M. L., 1980, The geology of the Drum Mountains: Millard and Juab counties, Utah: Brigham Young University Geology Studies, v. 27, p. 55-72.

Friedman, S. J., and Burbank, D. W., 1995, Rift basins and supradetachment basins: Intracontinental end members: Basin Research, v. 7, p. 109-127.

Gans, P. B., 1987, An open-system, two-layer crustal stretching model for the eastern Great Basin: Tectonics, v. 6 , p. $1-12$.

George, S. E., 1985, Structural Geology of the Pavant mountain front in the Fillmore and Kanosh Quadrangles, Millard County, Utah: Brigham Young University Geology Studies, v. 32, no. 1, p. 39-61.

Gregory-Wodzicki, K. M., 1997, The late Eocene House Range flora, Sevier Desert, Utah: Paleoclimate and paleoelevation: Palaios, v. 12, p. 552-567.

Gurnis, M., 1992, Rapid continental subsidence following the initiation and evolution of subduction: Science, v. 255, p. $1556-1558$.

1993, Phanerozoic marine inundation of continents driven by dynamic topography above subducting slabs: Nature, v. 364, p. 589-593.

Hamilton, W., 1994, "Sevier Desert detachment," Utah - A nonexistent structure: Geological Society of America Abstracts with Programs, v. 26, no. 2, p. 57.

Hintze, L. F., 1980, Geologic map of Utah: Salt Lake City, Utah Geological and Mineral Survey, scale 1:500,000. 1984, Geology of the Cricket Mountains, Millard County, Utah: United States Geological Survey Open-File Report 84-683.

- 1993, Geologic history of Utah: Brigham Young University Geology Studies Special Publication 7, 202 p.

Hintze, L. F., and Davis, F. D., 2003, Geology of Millard County, Utah: Utah Geological Survey Bulletin 133, 305 p.

Holladay, J. C., 1984, Geology of the northern Canyon Range, Millard and Juab counties, Utah: Brigham Young University Geology Studies, v. 31, p. 1-28.

Hossack, J., 1995, Geometric rules of section balancing for salt structures, in Jackson, M. P. A., Roberts, D. G., and Snelson, S., editors, Salt tectonics: A global perspective: American Association of Petroleum Geologists Memoir 65, p. 29-40.

Jackson, J. A., 1987, Active normal faulting and crustal extension, in Coward, M. P., Dewey, J. F., and Hancock, P. L., editors, Continental extensional tectonics: Geological Society Special Publication 28, p. 3-18.

Lindsey, D. A., 1982, Tertiary volcanic rocks and uranium in the Thomas Range and northern Drum Mountains, Juab County, Utah: United States Geological Survey Professional Paper 1221, 71 p.

Lindsey, D. A., Glanzman, R. K., Naeser, C. W., and Nichols, D. J., 1981, Upper Oligocene evaporites in basin fill of Sevier Desert region, western Utah: American Association of Petroleum Geologists Bulletin, v. 65, p. 251-260.

Lister, G. S., and Davis, G. A., 1989, The origin of metamorphic core complexes and detachment faults formed during Tertiary continental extension in the northern Colorado River region, U.S.A.: Journal of Structural Geology, v. 11, p. 65-94.

McDonald, R. E., 1976, Tertiary tectonics and sedimentary rocks along the transition: Basin and Range province to plateau and thrust belt province, Utah, in Hill, J. G., editor, Symposium on geology of the Cordilleran hingeline: Denver, Rocky Mountain Association of Geologists, p. 281-317.

Michaels, R. B., and Hintze, L. F., 1992, Interim geologic map of the Scipio Pass quadrangle, Millard County, Utah: Salt Lake City, Utah Geological Survey Open-File Report 246, scale 1:24,000.

Millard, A. W., 1983, Geology of the southwestern quarter of the Scipio North (15-minute) quadrangle, Millard and Juab counties, Utah: Brigham Young University Geology Studies v. 30 (part 1), p. 59-81.

Miller, E. L., Gans, P. B., and Garing, J. D., 1983, The Snake Range décollement: An exhumed mid-Tertiary brittle-ductile transition: Tectonics, v. 2, p. 239-263.

Mitchell, G. C., 1979, Stratigraphy and regional implications of the Argonaut Energy No. 1 Federal, Millard County, Utah, in Newman, G. C., and Goode, H. D., editors, Basin and Range symposium and Great Basin field conference: Denver, Rocky Mountain Association of Geologists, p. 503-514.

Mitchell, G. C., and McDonald, R. E., 1986, History of Cenozoic extension in central Sevier Desert, west-central Utah, from COCORP seismic reflection data: Discussion: American Association of Petroleum Geologists Bulletin, v. 70, p. 1015-1021.

- 1987, Subsurface Tertiary strata, origin, depositional model and hydrocarbon potential of the Sevier Desert basin, west central Utah, in Kopp, R. S., and Cohenour, R. E., editors, Cenozoic geology of western Utah-Sites for precious metal and hydrocarbon accumulations: Utah Geological Association Publication 16, p. 533-556.

Mitra, G., and Sussman, A. J., 1997, Structural evolution of connecting splay duplexes and their implications for critical taper: an example based on geometry and kinematics of the Canyon Range culmination, Sevier Belt, central Utah: Journal of Structural Geology, v. 19, p. 503-521.

Mitrovica, J. X., Beaumont, C., and Jarvis, G. T., 1989, Tilting of continental interiors by the dynamical effects of subduction: Tectonics, v. 8, p. 1079-1094.

Nash, W. P., 1986, Distribution, lithology, and ages of Late Cenozoic volcanism on the eastern margin of the Great Basin, west-central Utah: Department of Energy Contract DEACO780 ID 12079, Final Report, Salt Lake City, University of Utah. 
Otton, J. K., 1995, Western frontal fault of the Canyon Range: Is it the breakaway zone of the Sevier Desert detachment?: Geology, v. 23, p. 547-550.

1996, Western frontal fault of the Canyon Range: Is it the breakaway zone of the Sevier Desert detachment?: Reply: Geology, v. 24, p. 668-669.

Oviatt, C. G., 1989, Quaternary geology of a part of the Sevier Desert, Millard County, Utah: Utah Geological and Mineral Survey Special Studies 70, $41 \mathrm{p}$.

— 1991, Quaternary geology of the Black Rock Desert, Millard County, Utah: Utah Geological and Mineral Survey Special Studies 73, 23 p.

Parsons, T., and Thompson, G. A., 1993, Does magmatism influence low-angle normal faulting?, Geology, v. 21, p. 247-250.

Peterson, J. B., and Nash, W. P., 1980, Geology and petrology of the Fumarole Butte volcanic complex, Utah, in Studies in Late Cenozoic volcanism in west-central Utah: Utah Geological and Mineral Survey Special Studies 52, p. 34-58.

Planke, S., ms, 1987, Cenozoic structures and evolution of the Sevier Desert basin, west-central Utah, from seismic reflection data: Master's thesis, University of Utah, Salt Lake City, 163 p.

Planke, S., and Smith, R. B., 1991, Cenozoic extension and evolution of the Sevier Desert basin, Utah, from seismic reflection, gravity, and well $\log$ data: Tectonics, v. 10, p. 345-365.

Proffett, J. M., Jr., 1977, Cenozoic geology of the Yerington district, Nevada, and implications for the nature and origin of Basin and Range faulting: Geological Society of America Bulletin, v. 88, p. 247-266.

Ricci Lucchi, F., 1986, The Oligocene to Recent foreland basins of the northern Apennines, in Allen, P. A., and Homewood, P., editors, Foreland basins: International Association of Sedimentologists Special Publication 8, p. 105-139.

Royse, F., Jr., 1993, Case of the phantom foredeep: Early Cretaceous in west-central Utah: Geology, v. 21, p. 133-136.

Sharp, J. W., ms, 1984, West-central Utah: Palinspastically restored sections constrained by COCORP seismic reflection data: Master's thesis, Cornell University, Ithaca, New York, 60 p.

Smith, R. B., and Bruhn, R. L., 1984, Intraplate extensional tectonics of the eastern Basin and Range; Inferences on the structural style from seismic reflection data, regional tectonics, and thermalmechanical models of brittle-ductile deformation: Journal of Geophysical Research, v. 89, p. 5733-5762.

Smithson, S. B., and Johnson, R. A., 1989, Crustal structure of the western U.S. based on reflection seismology, in Pakiser, L. C., and Mooney, W. D., editors, Geophysical framework of the continental United States: Geological Society of America Memoir 172, p. 577-612.

Spencer, J. E., and Chase, C. G., 1989, Role of crustal flexure in initiation of low-angle normal faults and implications for structural evolution of the Basin and Range province: Journal of Geophysical Research, v. 94 , p. $1765-1775$.

Stein, R. S., King, G. C. P., and Rundle, J. B., 1988, The growth of geological structures by repeated earthquakes 2. Field examples of continental dip-slip faults: Journal of Geophysical Research, v. 93, p. 13,319-13,331.

Stewart, J. H., 1978, Basin-range structure in western North America: A review, in Smith, R. B., and Eaton, G. P., editors, Cenozoic tectonics and regional geophysics of the western Cordillera: Geological Society of America Memoir 152, p. 1-31.

Stockli, D. F., and Linn, J. K., 1996, Apatite fission-track thermochronology of the Canyon Range, Utah: Exhumation of the breakaway zone of the Sevier Desert detachment: Geological Society of America Abstracts with Programs, v. 28, no. 6, p. A-116.

Stockli, D. F., Linn, J. K., Walker, J. D., and Dumitru, T. A., 2001, Miocene unroofing of the Canyon Range during extension along the Sevier Desert Detachment, west central Utah: Tectonics, v. 20, p. 289-307.

Turley, C. H., and Nash, W. P., 1980, Petrology of late Tertiary and Quaternary volcanism in western Juab and Millard counties, Utah, in Studies in Late Cenozoic Volcanism in West-Central Utah: Utah Geological and Mineral Survey Special Studies 52, p. 1-33.

Villien, A., and Kligfield, R. M., 1986, Thrusting and synorogenic sedimentation in central Utah, in Peterson, J. A., editor, Paleotectonics and sedimentation in the Rocky Mountain region, United States: American Association of Petroleum Geologists Memoir 41, p. 281-308.

Von Tish, D. B., Allmendinger, R. W., and Sharp, J. W., 1985, History of Cenozoic extension in central Sevier Desert, west-central Utah, from COCORP seismic reflection data: American Association of Petroleum Geologists Bulletin, v. 69, p. 1077-1087.

Wernicke, B., 1981, Low-angle normal faults in the Basin and Range Province: Nappe tectonics in an extending orogen: Nature, v. 291, p. 645-648.

1985, Uniform-sense normal simple shear of the continental lithosphere: Canadian Journal of Earth Science, v. 22, p. 108-125.

— 1995, Low-angle normal faults and seismicity: A review: Journal of Geophysical Research, v. 100, p. $20,159-20,174$.

Wernicke, B. P., and Axen, G. J., 1988, On the role of isostasy in the evolution of normal fault systems: Geology, v. 16, p. 848-851.

Wills, S., ms., 2000, Evaluating models of detachment faulting: Ph.D. thesis, Columbia University, New York, 410 p.

Wills, S., and Anders, M. H., 1996, Western frontal fault of the Canyon Range: Is it the breakaway zone of the Sevier Desert detachment?: Comment: Geology, v. 24, p. 667-668.

— 1999, Tertiary normal faulting in the Canyon Range, eastern Sevier Desert: Journal of Geology, v. 107, p. $659-682$

Wills, S., and Buck, W. R., 1997, Stress-field rotation and rooted detachment faults: A Coulomb failure analysis: Journal of Geophysical Research, v. 102, p. 20,503-20,514.

Yin, A., 1989, Origin of regional, rooted low-angle normal faults: A mechanical model and its tectonic implications: Tectonics, v. 8, p. 469-482. 